UNIVERSIDADE DE SÃO PAULO

PROGRAMA INTERUNIDADES EM ENERGIA

ESCOLA POLITÉCNICA - FACULDADE DE ECONOMIA E ADMINISTRAÇÃO INSTITUTO DE ELETROTÉCNICA E ENERGIA - INSTITUTO DE FISICA

\title{
ORIENTAÇÃO DE TARIFAS DE ENERGIA ELÉTRICA PARA A EFICIENCIA ECONÔMICA E ENERGÉTICA
}

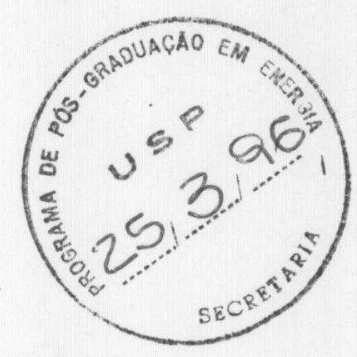

Dissertação apresentada ao Programa Interunidades de Pós-Graduação em Energia da Universidade de São Paulo para obtenção do título de Mestre em Energia. 
UNIVERSIDADE DE SÃO PAULO

PROGRAMA INTERUNIDADES EM ENERGIA

ESCOLA POLITÉCNICA - FACULDADE DE ECONOMIA E ADMINISTRAÇÃO INSTITUTO DE ELETROTÉCNICA E ENERGIA - INSTITUTO DE FÍSICA

\section{ORIENTAÇÃO DE TARIFAS DE ENERGIA ELETRICA PARA A EFICIENCIA ECONÔMICA E ENERGÉTICA}

Dissertação apresentada ao Programa Interunidades de Pós-Graduação em Energia da Universidade de São Paulo para obtenção do título de Mestre em Energia.

Aluno: DEMÓSTENES BARBOSA DA SILVA

Orientador: Prof. Dr. JOSÉ ROBERTO MOREIRA 
A todos quantos necessitam de informações úteis à promoção da eficiência do consumo e da oferta de eletricidade.

Razão também é escolha.

(Paradise Lost) 


\section{AGRADECIMENTOS}

Aos professores e companheiros do Instituto de Eletrotécnica e Energia da USP, em particular ao Prof. David Zylberstajn, pelo incentivo e condições proporcionadas ao desenvolvimento deste trabalho.

Aos Eng ${ }^{\circ}$. Dorel Soares Ramos, Eng ${ }^{\circ}$. João Gilberto Mazzon, Engº. Roberto Castro, e, ao Econ. Fernão Rodrigues Almeida, pelas informações fornecidas e pela disposição em examinar assuntos fundamentais tratados nesta dissertação.

Aos meus pais, esposa, filhas e filho, o apoio, incentivo e compreensão pelas horas de ausência ao longo de vários meses.

Ao Prof. JOSÉ ROBERTO MOREIRA, pela orientação segura, efetiva e constante apoio, fundamentais para a realização desta dissertação.

Finalmente descjo ressaltar minha intcira responsabilidade pelas insuficiências ou erros que se possam aqui verificar. 


\section{RESUMO}

Dentro do contexto da eficiência energética, as tarifas são consideradas instrumentos para a otimização da expansão e da operação do sistema.

A orientação de tarifas para a eficiência energética pode adotar os custos marginais como referência, considerando que os mesmos incorporam os reflexos do comportamento da demanda e da gestão do sistema.

No Brasil-a demanda por energia elétrica tem crescido entre $5 \%$ a $6 \%$ ao ano, o que significa decidir-se pela construção de uma nova usina de 1500 MW a cada ano, necessitando de investimentos anuais da ordem de US $\$ 3,9$ bilhões para o programa de expansão.

A relação de causa e efeito presente na metodologia de custos marginais permite correlacionar as decisões dos usuários do sistema elétrico quanto ao seu consumo, e as decisões dos gestores do mesmo ao equacionarem a oferta de eletricidade, indicando caminhos para a eficiência econômica e energética.

Confere, portanto, aos custos marginais a característica de base econômica para a orientação da eficiência dos usos finais de eletricidade.

A presente dissertação propõe uma política tarifária que promove a redução do consumo de eletricidade, tornando-o mais eficiente energética e economicamente. 


\begin{abstract}
In the context of energy efficiency tariffs are considered ways to optimize the expansion and operation of electric system.

In order to achieve energy efficiency we should consider marginal costs as a basis to tariffs, because they incorporate the signs of demand and the companies management in offering energy.

In Brazil the demand is expected to grow $5 \%$ or $6 \%$ each year which means the necessity to build a new 1500 Megawatts power plant per year, corresponding to investiments of US\$ 3.9 billion per year for the expansion program.
\end{abstract}

The cause and effect relationship used in the methodology of marginal costs enables to the decisions of the consumers related to demand and the action of the utilities to offer electricity, so that it indicates the way to economic and efficient use of the system.

This dissertation proposes a tariff policy that would reduce the consumption of energy, making it more efficient than the current one. Thus, it would also increase the economic efficiency. 


\section{SÍMBOLOS}

$\$$

- Unidade Monetária

dy/dx - Derivada de uma função linear y em relação à variável $x$

- Derivada Parcial

$\Sigma$

- Somatória 


\section{ABREVIATURAS}

\begin{tabular}{|c|c|}
\hline $\mathrm{kCal}$ & - Quilo Caloria \\
\hline MWano & - MegaWatts durante um ano \\
\hline MWh & - MegaWatts durante uma hora \\
\hline $\mathrm{kWh}$ & - QuiloWatts durante uma hora \\
\hline MW & - MegaWatts \\
\hline O\&M & - Operação e Manutenção \\
\hline $\mathrm{CV}$ & - Cavalo Vapor \\
\hline \multicolumn{2}{|c|}{ ELETROBRAS - Centrais Elétricas Brasileiras } \\
\hline JDC & - Juros Durante a Construção \\
\hline PIB & - Produto Interno Bruto \\
\hline ENERSUL & - Empresa de Energia Elétrica do Mato Grosso do Sul \\
\hline UHE & - Usina Hidroelétrica \\
\hline OCDE & - Organização para a Cooperação e Desenvolvimento Econômico \\
\hline COPPE/AIE & $\begin{array}{l}\text { - Coordenação dos Programas de Pós-Graduação em Engenharial } \\
\text { Área Interdisciplinar de Energia }\end{array}$ \\
\hline CME & - Custo Marginal de Expansão \\
\hline CMO & - Custo Marginal de Operação \\
\hline
\end{tabular}




\section{SUMÁRIO}

INTRODUÇÃO_................................................................................................................... 01

CAPÍTULO I............................................................................................................... 03

1-OsPensadores daEconomia - Suas Teorias dePreços .......................................... 03

2-Bases de Custos Para as Tarifas-Metodologias de Cálculo .................................. 15

CAPÍTULO II..................................................................................................................... 25

1-OModelo Tarifário-Síntese Cronológica ……………………...................... 25

1.1-Considerações Gerais ............................................................................ 25

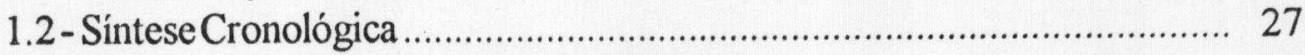

2-APressão da Demanda naExpansão do Sistema ………………………….......... 30

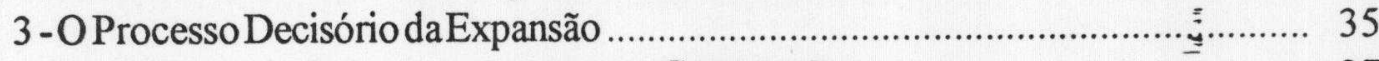

4-Acréscimos de Custos por Atrasos nas Construções ........................................... 37

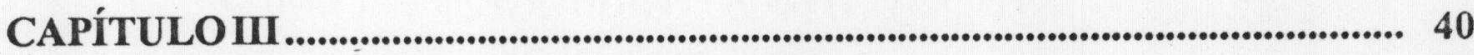

1 - Considerações sobre a Orientação de Tarifas .................................................... 40

1.1-Escopo eObjetivos da Tarifação ……………………………………...... 40

1.2-Orientação das Tarifas ..................................................................... 41

1.3-Orientação para aEficência Econômica eEnergética …………………..... 45

2 - Proposta de Fixação de Tarifas de Forma Orientada para EficiênciaEnergética ........................................................................ 47

3 - Valor Econômico do Sinal Tarifário ................................................................ 48

4 - Exercício de Cálculo de Sinal Tarifário para a Proposta de

Orientação de Tarifas .................................................................................... 49

4.1 - Simulação do Sistema para Atendimento do Mercado Previsto sema Redução por Eficiência .................................................. 50

4.2 - Simulação do Sistema para Atendimento do Mercado

Previsto coma Redução por Eficiência .................................................... 52

5 - A Proposta de Orientação de Tarifas como uma Forma

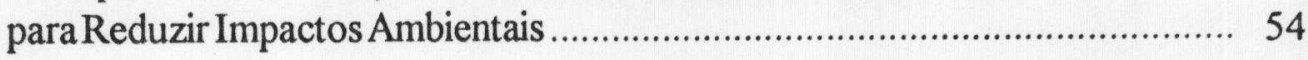

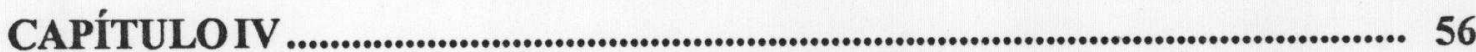

CONCLUSÕES..................................................................................................... 56

ANEXOS

ANEXOI

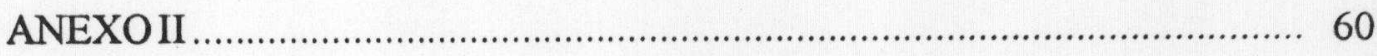

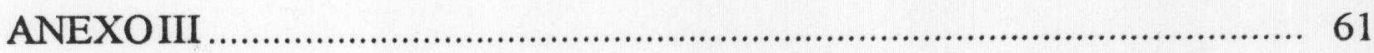

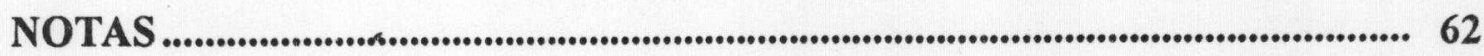

REFERÊNCIAS BIBLIOGRÁFICAS .............................................................. 64

APÊNDICES

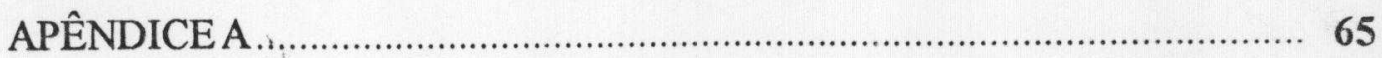

APÊNDICEB 


\section{LISTA DE TABELAS}

Tabela 1 - Preços e Demandas em um Monopólio .................. 08

Tabela 2 - Preços e Demandas Parciais num Monopólio ............. 09

Tabela 3 - Composição dos Custos Marginais de Expansão e Operação ...... 19

Tabela 4 - Comparação Internacional de Tarifas $\ldots \ldots \ldots \ldots \ldots \ldots$

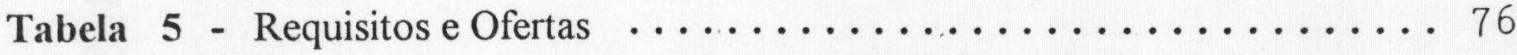

Tabela 6 - Previsão do Mercado de Energia Elétrica Crescimento do PIB e Elasticidade .............. 77

Tabela 7 - Projeções de Demanda para o ano 1990 Sistema Interligado SUDESTE/CENTRO OESTE/SUL . . . . . 78

Tabela 8 - Consumo de Energia Elétrica no Estado de São Paulo ....... 79

Tabela 9 - Regressões das Séries de Consumo, PIB e Preço da Energia ..... . 80

Tabela 10 - Condições de Atendimento - Ciclo $92 \ldots \ldots \ldots \ldots \ldots \ldots \ldots \ldots$

Tabela 11 - Simulação do Sistema sem Redução do Mercado Conjunto de Obras e Datas de Entrada em Operação $\ldots . . . . .82$

Tabela 12 - Sistema Interligado SUL/SUDESTE Comparativo das Previsões para o ano 1992

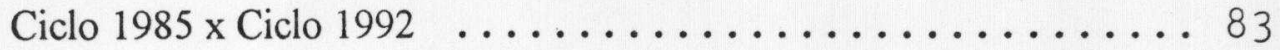

Tabela 13 - Inflação e PIB - $1980-1990 \ldots \ldots \ldots \ldots \ldots \ldots \ldots \ldots \ldots$. . . . 84

Tabela 14 - Sistema Interligado SUL/SUDESTE Comparativo entre Cronogramas de Entrada em Operações em 1992 Ciclo 1985 x Ciclo 1992 . . . . . . . . . . . . 85

Tabela 15 - Crescimento de Custos em Projetos Hidroelétricos Distribuição Percentual das Variações Verificadas $\ldots . . . . .86$

Tabela 16 - Distribuição por Faixas de Crescimento - Projetos Hidroelétricos . . . 87

Tabela 17 - Projeções de Mercado $(\mathrm{GWh}) \ldots \ldots \ldots \ldots \ldots \ldots \ldots$

Tabela 18 - Investimentos (US\$ $* 10 \mathrm{E} 6) \quad \ldots \ldots \ldots \ldots \ldots \ldots \ldots \ldots$

Tabela 19 - Tarifas Médias de Fornecimento - CESP .............. 90

Tabela 20 - Geração Interna de Recursos x Investimentos Programados ...... . 91

Tabela 21 - Potencial de Redução do Consumo ................ 92

Tabela 22 - Oferta e Risco de Déficit $\ldots \ldots \ldots \ldots \ldots \ldots \ldots \ldots \ldots$ 
Tabela 23 - Sistema Interligado SUL/SUDESTE

Cálculo do Custo Marginal de Expansão $\ldots \ldots \ldots \ldots \ldots \ldots . \ldots \ldots$

Tabela 24 - Sistema Interligado SUL/SUDESTE

Investimentos no Programa Decenal de Geração . . . . . . . . . 95

Tabela 25 - Sistema Interligado SUL/SUDESTE

Cálculo do Custo Anual de Operação e Manutenção

(COME) e Acréscimo de Ponta $\ldots \ldots \ldots \ldots \ldots \ldots \ldots \ldots \ldots$

Tabela 26 - Sistema Interligado SUL/SUDESTE

Cálculo do Custo Marginal de Expansão

Incremento da Oferta de Energia a 5\% de Risco Anual - ICEQ (MWano) . . 97

Tabela 27 - Sistema Interligado SUL/SUDESTE

Cálculo do Custo Marginal de Expansão

Estimativa do Mercado Atendido por Nucleares $\ldots \ldots \ldots \ldots \ldots \ldots .98$

Tabela 28 - Sistema Interligado SUL/SUDESTE

Cálculo do Custo Marginal de Expansão

Custos Equivalentes Atualizados e Custo Marginal de Expansão . . . . . . . 99

Tabela 29 - Sistema Interligado SUL/SUDESTE

Investimentos no Programa Decenal de Geração $\ldots \ldots \ldots \ldots \ldots$. . . 100

Tabela 30 - Sistema Interligado SUL/SUDESTE

Cálculo do Custo Anual de Operação e Manutenção

(COME) e Acréscimo de Ponta ...................... 101

Tabela 31 - Sistema Interligado SUL/SUDESTE

Cálculo do Custo Marginal de Expansão

Incremento da Oferta de Energia a 5\% de Risco Anual - ICEQ (MWano) . . 102

Tabela 32 - Sistema Interligado SUL/SUDESTE

Cálculo do Custo Marginal de Expansão

Estimativa do Mercado Atendido por Nucleares ........... 103

Tabela 33 - Oferta e Risco de Déficit com Redução de $5 \%$............ 104 


\section{INTRODUÇÃO}

O contexto do aumento da eficiência no consumo dos diversos energéticos alcança a eletricidade no Brasil como uma das oportunidades mais promissoras, devido à representatividade do sistema elétrico brasileiro no mix das fontes que compoem a oferta total de energia no Pais, devido à magnitude dos recursos de capital que são aplicados no sistema eletroenergético e ainda, devido ao potencial de aumento da eficiência dos usos finais de eletricidade.

A implementação de estratégias que promovam o incremento dessa eficiência, entretanto, depende de orientações e dispositivos que sensibilizem os agentes (consuṇiidores, gestores do sistema, fabricantes de equipamentos e financiadores) a atuarem no sentido pretendido, tendo como resultado beneficios claramente identificáveis em correspondência às suas ações.

Uma das formas mais objetivas para a orientação das ações dos agentes em um sistema é a sinalização econômica para suas ações, que pode ser estabelecida através de tarifas com orientações especificas.

Citamos um exemplo da eficácia dessas orientações, qual seja: a política de venda de energia elétrica como substitutiva de derivados de petróleo, implementada no Brasil nos primeiros anos após o segundo choque do petróleo, quando foram ofertadas modalidades de energia com tarifas bastante reduzidas (EGTD - Energia Garantida por Tempo Determinado e ESNG - Energia Sazonal Não Garantida). Tal Politica proporcionou significativo aumento do consumo de eletricidade e redução do consumo de óleo combustível, ações efetivas de diversos agentes além dos consumidores (indústria de equipamentos - caldeiras elétricas, agentes financeiros e companhias de eletricidade).

Também oportuno citar a politica de preços mais elevados para a gasolina, ao final da década de 70 e início de 80 , quando o consumo foi realmente racionalizado, ensejando o início de uma nova fase de desenvolvimento de projetos de veículos mais econômicos, entrando em cena ações dos fabricantes de automóveis, motoristas tentando economizar com maior atenção em seus hábitos ao dirigir, além de ter ensejado, sob certos aspectos, as decisões de milhares de consumidores de aderirem ao programa nacional do álcool.

Entendemos, portanto, que há um considerável potencial para promover a eficiência do consumo de eletricidade através da sinalização tarifária. Especificamente, as tarifas participariam como coadjuvantes em programas de incremento da eficiência, apresentando de forma clara os beneficios resultantes das ações dos consumidores, e também, dos demais agentes, como as companhias de eletricidade, podendo atender a maiores números de consumidores com menores 
expansões de seus sistemas, os agentes financeiros, os quais no caso do sistema elétrico brasileiro são principalmente instituições internacionais, podendo ter uma maior produtividade tanto econômica como social para o capital aplicado, e, os fabricantes de equipamentos eficientes, tendo a motivação dos consumidores para um mercado emergente.

Esta dissertação procura rever as bases conceituais econômicas dos preços de energia, caracterizar os mecanismos decisórios do processo de expansão e tarifação do sistema elétrico brasileiro, e, apresentar uma proposta para orientação de tarifas à eficiência do consumo.

No Capitulo I é apresentada uma revisão da literatura sobre as teorias de preços dos pensadores da economia, e, sobre as metodologias atualmente empregadas no cálculo de tarifas. São analisadas as formações de preços com base em custos médios e custos marginais, e, em certos pontos das discussões apresentadas são feitas colocações sobre os objetivos especificos do incremento da eficiência.

No Capitulo II é caracterizada a prática atual das tarifas no setor elétrico nacional, para tanto é apresentado um histórico do modelo tarifário, são comentados o processo decisório de expansão e a pressão que a demanda por eletricidade exerce naquele processo, e, são comentados alguns efeitos indesejáveis de atrasos nas construções de obras do sistema, que poderiam ser minimizados como beneficio de programas de incremento da eficiência com tarifas orientadas.

Finalmente no Capitulo III é apresentada uma proposta para orientação de tarifas, bem como um exemplo da mesma, considerando como sinal orientativo para o incremento da eficiência o valor econômico do benefício da redução do consumo projetado, dada determinada meta a ser alcançada com o programa de orientação à eficiência. 


\section{CAPÍTULO I}

\section{OS FUNDAMENTOS TEÓRICOS DOS PREÇOS DA ENERGIA}

\section{1 - OS PENSADORES DA ECONOMIA - SUAS TEORIAS DE PREÇOS}

Em um estudo da história do pensamento econômico pode-se observar que algumas teorias foram formuladas sobre a formação de preços de recursos esgotáveis. No cașo específico da energia, a mesma foi considerada como um desses recursos, um estoque da natureza, tanto na escola clássica como na neo-clássica.

Adam Smith, um dos principais representantes da escola clássica, marcou o pensamento econômico do século XIX com sua obra A Riqueza das Naçz̃es ${ }^{(i)}$, a qual é atualmente considerada um marco do início do enfoque cientifico na análise de fenômenos econômicos, e, contém uma das primeiras descrições do significado da formação de preços naturais e de mercado(1).

Os preços naturais, segundo aquela descrição, correspondem ao exato valor atribuído à renda da terra, aos salários do trabalho e aos lucros do capital empregado para obter, preparar e levar determinada mercadoria ao mercado.

Os preços de mercado, segundo a mesma descrição, correspondem aos valores pelos quais as mercadorias são efetivamente comercializadas. Os mesmos podem estar acima ou abaixodos preços naturais, em função das quantidades das mercadorias colocadas no mercado; quando a quantidade for inferior à demanda efetiva o preço de mercado sobe acima do preço natural; quando não existir excesso ou carência de oferta, os preços de mercado e natural são coincidentes.

Smith elaborou o fundamento da teoria dinâmica de mercado, ou seja, o ajuste da demanda e da oferta através da variação do emprego dos fatores. No pensamento dos clássicos, o fator principal mediante cuja variação é processado o ajuste é o capital, decorrente do efeito de excessos ou insuficiências de oferta, através dos preços.

Em sua obra, Smith não fez distinção entre mercadorias, nem quanto à sua origem, se de recursos esgotáveis ou não, mas tratou de forma genérica o mecanismo dos preços.

Fez também alusão especifica aos preços em monopólios. Em sua alusão, apresentou o raciocínio de que num monopólio outorgado a um indivíduo ou a uma companhia que explore o comércio em um determinado mercado, a formação de seus preços é tratada de forma similar a um segredo comercial ou industrial. 
O monopolista, por manter o mercado sempre em falta, por nunca suprir plenamente a demanda efetiva, vende suas mercadorias acima de seus respectivos preços naturais, auferindo ganhos - quer consistam em baixos salários ou em lucros elevados - muito acima de sua taxa natural.

O preço do monopólio é em qualquer ocasião o mais alto que se pode conseguir da disposição dos compradores em pagar; c o preço natural é o mais baixo que os vendedores comumente podem aceitar se quizerem continuar a manter seu negócio.

Estava introduzida, assim, a noção do importante papel dos preços na alocação de recursos.

Outro dos principais representantes da escola clássica da Economia Política, o inglês David Ricardo contribuiu para o pensamento econômico clássico na époça em que se iniciava a Revolução Industrial, quando a produção em larga escala foi viabilizada mediante o uso de máquinas a vapor, e,quando a produtividade do trabalho deixou de depender da habilidade manual e passou a depender do aperfeiçoamento de instrumentos mecânicos de produção $0^{(i i)}$.

Ricardo postulava uma tcoria na qual o valor de uma mercadoria depende da quantidade relativa de trabalho necessário para sua produção, e não da maior ou menor remuneração que é paga por esse trabalho(2), dessa forma, os valores das mercadorias são funções diretas de sua escassez e da quantidade de trabalho necessária para produzí-las.

Scbre os monopólios, Ricardo apresentou conclusões idênticas às de Smith, quais sejam, a elevação ou redução de preços depende da disposição do monopolista em colocar quantidades maiores ou menores de mercadoria à disposição dos compradores, e, da disposição destes últimos em pagar.

Igualmente sobre a livre concorrência, concluiu que os preços nesse regime não dependem exclusivamente da situação da demanda e da oferta, mas também, e principalmente, do aumento ou redução do custo de produção.

A Energia naquela época estava fortemente representada pelo carvão extraido das minas, e seu valor correspondia à soma dos valores das necessidades básicas dos trabalhadores empregados nas mesmas.

As teorias sobre preços, formuladas pelos célebres pensadores clássicos da economia política, consideravam sua formação com base no conceito do valor de troca ${ }^{(3)}$, estabelecendo uma equivalência entre a mercadoria e seu preço, sendo esse preço o valor da mercadoria em relação ao dinheiro, ou seja, a quantidade de dinheiro pela qual a mercadoria poderia ser trocada.

Em contraposição a esse conceito do valor de troca, Karl Henrich Marx ${ }^{(4)}$ apresentou a idéia de que o valor de uma mercadoria corresponderia à quantidade de trabalho social necessário para produzi-la, o que difere do postulado de Ricardo, na medida em que este último relaciona o valor 
da mercadoria ao valor do trabalho, ou scja, o salário, e Marx estabelece essa relação com base no esforço da sociedade, desempenhado com um nivel médio representativo de tecnologias empregadas nos processos produtivos, um nível médio sócio cultural dos trabalhadores, bem como um nivel médio de necessidades de bens e serviços ${ }^{(i i i)}$.

Ao colocar suas idéias sobre as relações entre os preços naturais e os de mercado, definiu a regulagem dos preços de mercado como sendo função da quantidade social média de trabalho, necessária para abastecer o mercado com determinada quantidade de certa mercadoria nas condições médias de produção.

E também, ao considerar que os preços naturais são formados pelą quantidade de trabalho necessário para sua oferta, conclui que não há razão plausivel para uma grande e duradoura diferença entre os preçoș de mercado e os naturais.

Diz não poder ser duradoura, porquanto tais diferenças refletem desequilibrios entre a oferta e a procura, os quais são eliminados através de ajustes da produção, imediatamente após a verificação do desequilibrio.

Assim, atribui ao absurdo a idéia de que os lucros, se verificados de forma contínua, têm origem nos preços de mercado, pois, sua existência é limitada ao tempo necessário ao ajuste.

No pensamento neo-clássico, a formação dos preços foi explicada com maior instrumentação matemática, mas harmonizando-se com as concepções dos clássicos sobre o assunto. A teoria do valor de troca foi mais completamente embasada, com a lei da variação da utilidade de um bem, segundo a qual a utilidade varia à medida de sua disponibilidade, segundo leis possíveis de serem expressas matematicamente, atendidas algumas premissas.

A teoria da troca recebeu assim um importante sustentáculo, passando a ser formulada nos seguintes termos: A relação de troca de dois bens quaisquer será correspondente à relação dos graus finais de utilidade das quantidades dos bens disponiveis para consumo depois que a troca se completa ${ }^{(i v)}$.

Jevons $^{(5)}$ expressou essa teoria graficamente e literalmente, exemplificando a troca de dois bens, cujas curvas de utilidade superpostas permitem a conclusão das relações de troca.

A figura a seguir ilustra as curvas de utilidade de dois bens. 


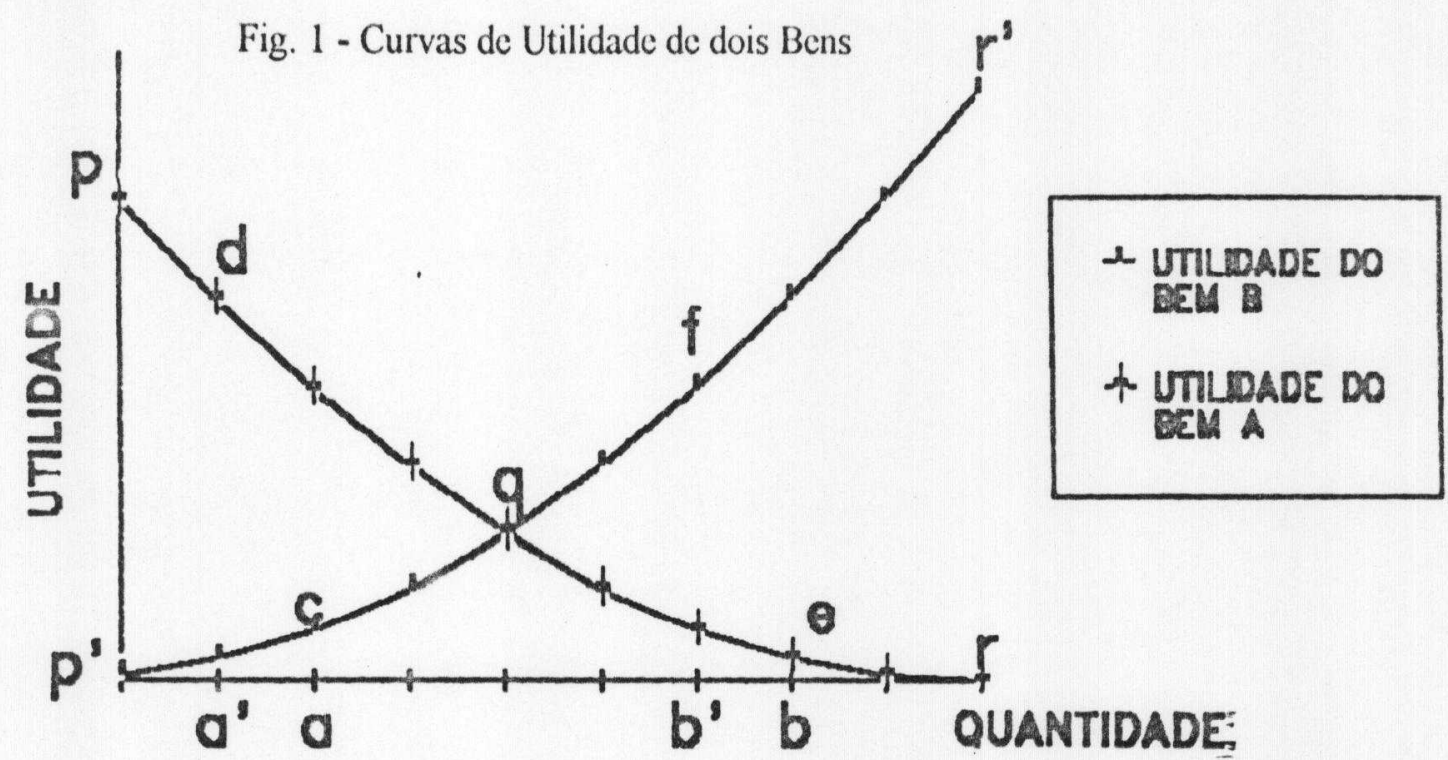

A fig. 1 acima representa pequenos segmentos das curvas de utilidade de dois bens (pqr e p'q r'). As quantidades dos bens são medidas no eixo horizontal, a quantidade de um dos bens é medida de a para b e do outro de $b$ para $a$.

Alguém que troque a quantidade infinitesimal a'a do primeiro bem pela mesma quantidade aa' do segundo bem, ganhará a utilidade ad, entretanto perderá a utilidade a'c. Tal pessoa pretenderá, portanto, fazer novas trocas de quantidades do bem medido na escala ba, das quais é possuidor, caso fizer trocas até chegar ao ponto b', e ainda continuar com a disposição em trocar, receberá pela próxima troca a utilidade be e perderá a utilidade b'f, perceberá então, que foi longe demais com as trocas, concluindo que o ponto de intersecção q entre as curvas define o ponto ótimo para as trocas.

A expressão literal desse processo é

$$
d y=\frac{y}{x} d x
$$

onde $\mathrm{x}$ e $\mathrm{y}$ representam os dois bens trocados.

Com esta expressão literal e gráfica do processo de trocas, torna-se evidente o princípio de que os graus de utilidade dos bens trocados estarão na proporção inversa das magnitudes dos acréscimos trocados.

As teorias então formuladas não se aplicavam perfeitamente ao caso da energia, devido às peculiaridades do suprimento e dos mercados dos principais energéticos, que não correspondiam a uma concorrência perfeita, mas esse era o embasamento conceitual consagrado.

Realmente, a produção de energia naquela época não suscitava maiores preocupações além da disponibilidade das fontes, a tecnologia para sua exploração e o custo de sua produção. 0 custo e a eficiência de sua utilização, hoje na tela das principais inquirições sobre a energia, não foram objeto de análises muito completas. 
Embora as teorias clássicas tenham exercido grande influĉncia na organização das atividades econômicas e sociais das nações, seus preceitos não foram exclusivamente aplicados em todas as áreas, como é o exemplo de alguns monopólios que existiram na Europa e ainda hoje existem cm países em desenvolvimento; temos no Brasil o exemplo do monopólio da prospecção e refino do petróleo.

Particularmente na produção de bens e serviços considerados como de infraestrutura, cujos investimentos necessitam ser realizados com antecedência em relação a outros que por sua vez necessitam da disposição prévia daqueles primeiros, como é o caso da energia elétrica.

A atuação supletiva e até mesmo monopolistica do estado, nesses casos, tem sido justificada pela necessidade de realizar a expansão da oferta, em condições nas quais a lịvre concorrência não alcançaria, por não ser interessante o emprego de capital para retorno às vezes baixo e lento.

Leon Walras estudou a formação dos preços das mercadorias em um ambiente de monopólio, ou seja um serviço produtivo ou produto $\mathrm{em}$ uma única mão.

Walras baseou-se na teoria do monopólio, demonstrando que a aplicação da mesma resulta na impossibilidade de que o preço de venda seja igual ao preço de custo e que esse preço seja um preço de mercado ${ }^{(v)}$.

Em sua interpretação, o monopolista é livre para fixar como bem entender o preço do produto; mas, não depende dele a quantidade do produto demandada a determinado preço. A lei de diminuição ou de aumento da demanda de acordo com a elevação ou a baixa do preço varia apenas de um produto para outro, conforme Cournot e Dupuit. ${ }^{(6)}$

Para qualquer produto há, de um lado, um preço máximo com o qual a demanda é nula, e de outro lado, uma demanda máxima com a qual o preço seria nulo, conforme ilustra a Fig. 2 a seguir:

Fig. 2 - Curvas Demanda x Preço

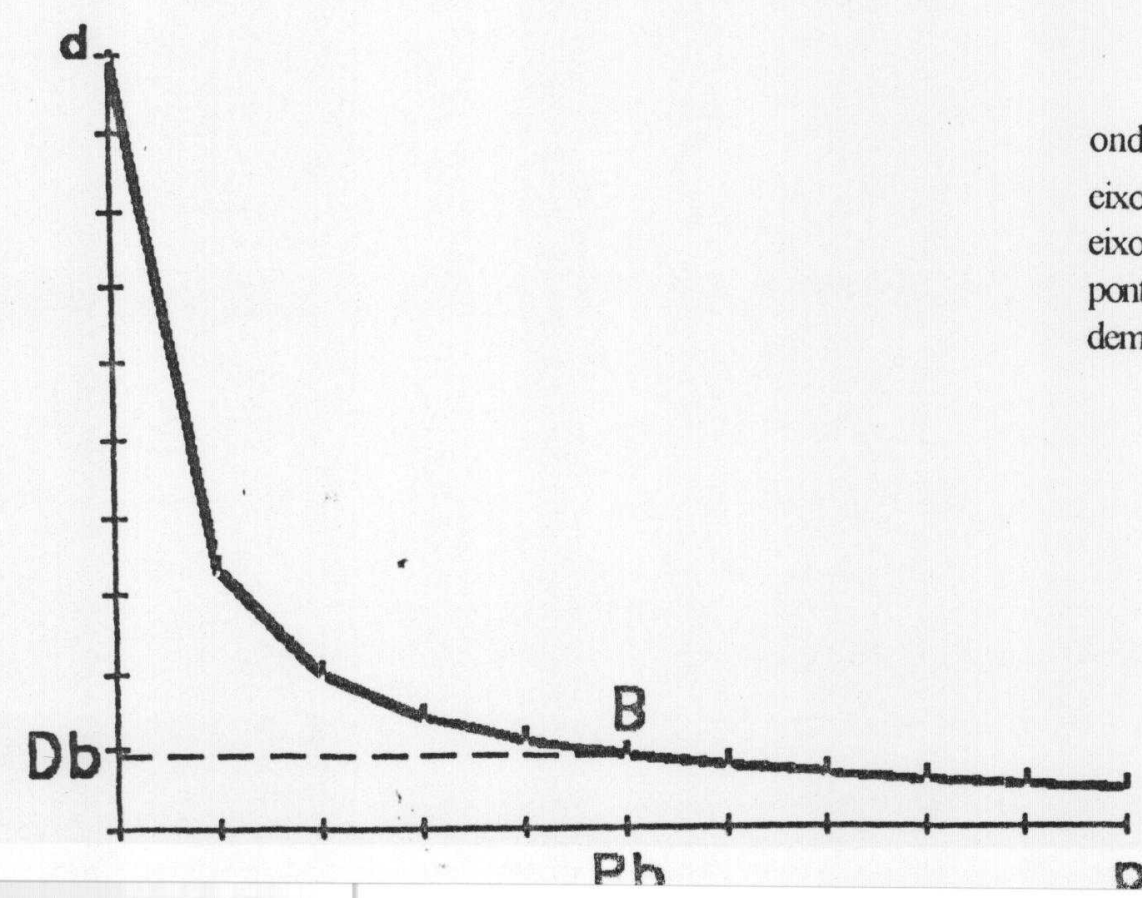




\begin{tabular}{|r|c|c|c|c|}
\hline Preço & Demanda & Receita Bruta & Despesas & Receita Líquida \\
S/kWh & $\mathbf{k W h}$ & $\mathbf{S} 10 \mathbf{E} 3$ & $\mathbf{S}$ & 0 \\
100 & 0 & 0 & 0 & 480 \\
50 & 10 & 500 & 20 & 900 \\
20 & 50 & 1000 & 100 & 3000 \\
5 & 1000 & 5000 & 2000 & 2500 \\
3 & 2500 & 7500 & 5000 & 0 \\
2 & 5000 & 10000 & 10000 & -12000 \\
1 & 12000 & 12000 & 24000 & -30000 \\
0.50 & 20000 & 10000 & 40000 & -100000 \\
0 & 50000 & 0 & 100000 & $\vdots$ \\
\hline
\end{tabular}

Aplicando-se o raciocínio desenvolvido por Walras, no caso de um monopólio de fornecimento de energia elétrica, suponhamos que a demanda por eletricidade em determinada classe seja nula ao preço de $\$ 100$ unidades monetárias por $\mathrm{kWh}$.

Suponhamos que variando o preço de $\$ 100$ a 0 , tenhamos demandas crescentes conforme a Tabela 1 acima.

Nota-se que o produto bruto aumenta com o aumento da demanda, mas somente até o nivel de preço $\$ 1 / \mathrm{kWh}$, a partir do qual decresce devido a um decréscimo na velocidade de crescimento da demanda, em proporção maior do que a redução do preço.

O monopolista ajustaria então o preço em $\$ 1 / \mathrm{kWh}$, se não considerasse seus custos de produção, que podem ser fixos ou variáveis, em função da quantidade de eletricidade produzida.

Considerando os custos variáveis iguais a $\$ 2 / \mathrm{kWh}$, o preço ótimo não mais seria $\$ 1$ / $\mathrm{kWh}$, mas $\operatorname{sim} \$ 5 / \mathrm{kWh}$, pois o produto líquido máximo com tal custo variável ocorrerá no nível de preço $\$ 5 / \mathrm{kWh}$, com $1000 \mathrm{kWh}$ de demanda.

Considerando também os custos fixos, qualquer que seja seu nivel o preço ótimo permaneceria em $\$ 5 / \mathrm{kWh}$, pois o mesmo independe dos custos fixos.

Demonstrou assim, que no monopólio os preços não são iguais e nem função do custo, mas da demanda ou melhor da utilidade do produto.

Com o mesmo exemplo da energia elétrica demonstra-se que o monopólio acaba também por violar a condição de que haja um único preço de mercado. Supondo que cada consumidor consuma $50 \mathrm{kWh}$, teriamos que $10 \mathrm{kWh}$ seriam vendidos a $\$ 20 / \mathrm{kWh}, 40 \mathrm{kWh}$ seriam vendidos a $\$ 20 / \mathrm{kWh}$.

Progredindo com o raciocínio de que para uma dada quantidade demandada a um preço qualquer, existe uma certa demanda que poderia ser colocada a um preço superior, pode-se supor que em vez de um único preço existam vários no mercado e que a cada um é vendida a quantidade 
parcial demandada.

No exemplo em questão, as demandas parciais e os produtos a cada preço teriam a configuração seguinte:

\begin{tabular}{|c|r|r|r|r|r|r|}
\hline Preso & $\begin{array}{c}\text { Demanda } \\
\text { Parcial } \\
\text { S/kWh }\end{array}$ & $\begin{array}{c}\text { Produto Bruto } \\
\text { Parcial } \\
\text { kWh }\end{array}$ & $\begin{array}{c}\text { Produto Bruto } \\
\text { Total } \\
S\end{array}$ & $\begin{array}{c}\text { Despesas } \\
\text { Parciais } \\
\mathbf{S}\end{array}$ & $\begin{array}{c}\text { Produto } \\
\text { Liquido Parcial } \\
S\end{array}$ & $\begin{array}{r}\text { Produto } \\
\text { Liquido Total } \\
\mathbf{S}\end{array}$ \\
100 & 0 & 0 & 0 & 0 & 0 & 0 \\
50 & 10 & 500 & 500 & 20 & 480 & 480 \\
20 & 40 & 800 & 1300 & 80 & 720 & 1200 \\
5 & 950 & 4750 & 6050 & 1900 & 2850 & 4050 \\
3 & 1500 & 4500 & 10550 & 3000 & 1500 & 5550 \\
2 & 2500 & 5000 & 15550 & 5000 & 0 & 5550 \\
1 & 7000 & 7000 & 22550 & 14000 & -7000 & -1450 \\
0.50 & 8000 & 4000 & 26550 & 16000 & -12000 & -13450 \\
0 & 30000 & 0 & 26550 & 60000 & -60000 & -73450 \\
\hline
\end{tabular}

Tabela 2 - Preços e Demandas Parciais num Monopólio

Nota-se que em se praticando os vários preços considerados ter-se-ia uma maximização do produto bruto total, o qual abatido das despesas resultaria na possibilidade de se praticar preços de $\$ 50 / \mathrm{kWh}, \$ 20 / \mathrm{kWh}, \$ 5 / \mathrm{kWh}$ e $\$ 3 / \mathrm{kWh}$, e ainda, poder-se-ia vender $2500 \mathrm{kWh}$ ao preço de custo.

Fica evidente que em um monopólio puro a alocação de recursos entre os setores da economia deixa de ser ótima. Fica também lógica a conclusão de que num País no qual o Estado seja o monopolista do mercado de energia elétrica, operando-o tal como um monopólio puro, tal sistema de preços não atenderia o interesse geral da população, além de não garantir a eqüidade social.

Embora não seja isso que exatamente ocorre em casos de monopólio estatal, pois, quando o Estado é o monopolista pressupostamente sua ação será coerente e balizada com o conjunto de interesses da nação, fixando preços de tal forma que se o preço fixado for acima do custo, o diferencial fará as vezes de um imposto e se o preço fixado for abaixo do custo, o diferencial deverá ter cobertura por imposto. Ocorre que esse pressuposto nem sempreé verdadeiro, e às vezes éde dificil implementação pelos governos.

Em 1909 Vilfredo Pareto apresentou sua obra intitulada Manuel d'Economie Politique ${ }^{(v i)}$, com uma abordagem diferente das até então realizadas sobre o problema dos custos e preços de bens e serviços numa sociedade.

Seu enfoque se deu sobre as uniformidades observadas nos fenômenos econômicos sociais, ou seja, sobre as teis que explicam seu comportamento.

Pareto se eximiu de propor receitas úteis aos particulares ou aos governos para sua atividade econômica e social, bem como de propor um tratado ou uma doutrina geral para regular relaçð̃es sócio-econômicas, como foram as intenções dos outros pensadores da economia até então. 
Ao descrever o equilibrio econômico em uma sociedade, define de forma imparcial os diversos agentes econômicos e as condições de aplicação e satisfação de fatores e desejos, caracterizando os ótimos no equilibrio da produção e no equilibrio da sociedade. 0 ótimo da produção é alcançado quando todos os preços dos diversos bens são iguais aos respectivos custos marginais de curto prazo, e o ótimo da sociedade é alcançado quando as diferenças entre as satisfações dos diversos agentes em relação aos bens produzidos pela sociedade são mínimas.

Não nos dedicaremos aqui a uma rigorosa demonstração matemática da teoria do equilíbrio formulada por Pareto, mas tentaremos ressaltar sua lógica imaginando sua aplicação no caso do Setor Elétrico Brasileiro.

Curva do Produto - podemos expressar a quantidade de energia produzida e colocada à disposição da sociedade, em função de todos os fatores que são empregados no sistema energético.

$$
E=f\left(x_{1}, x_{2}, x_{3}, \ldots \ldots \ldots, x_{n}\right)
$$

fatores esses que podem ser, por exemplo:

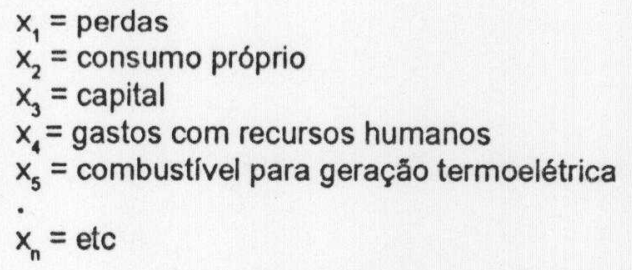

Podemos também representar graficamente a produção em função de um dos fatores, conforme a seguir.

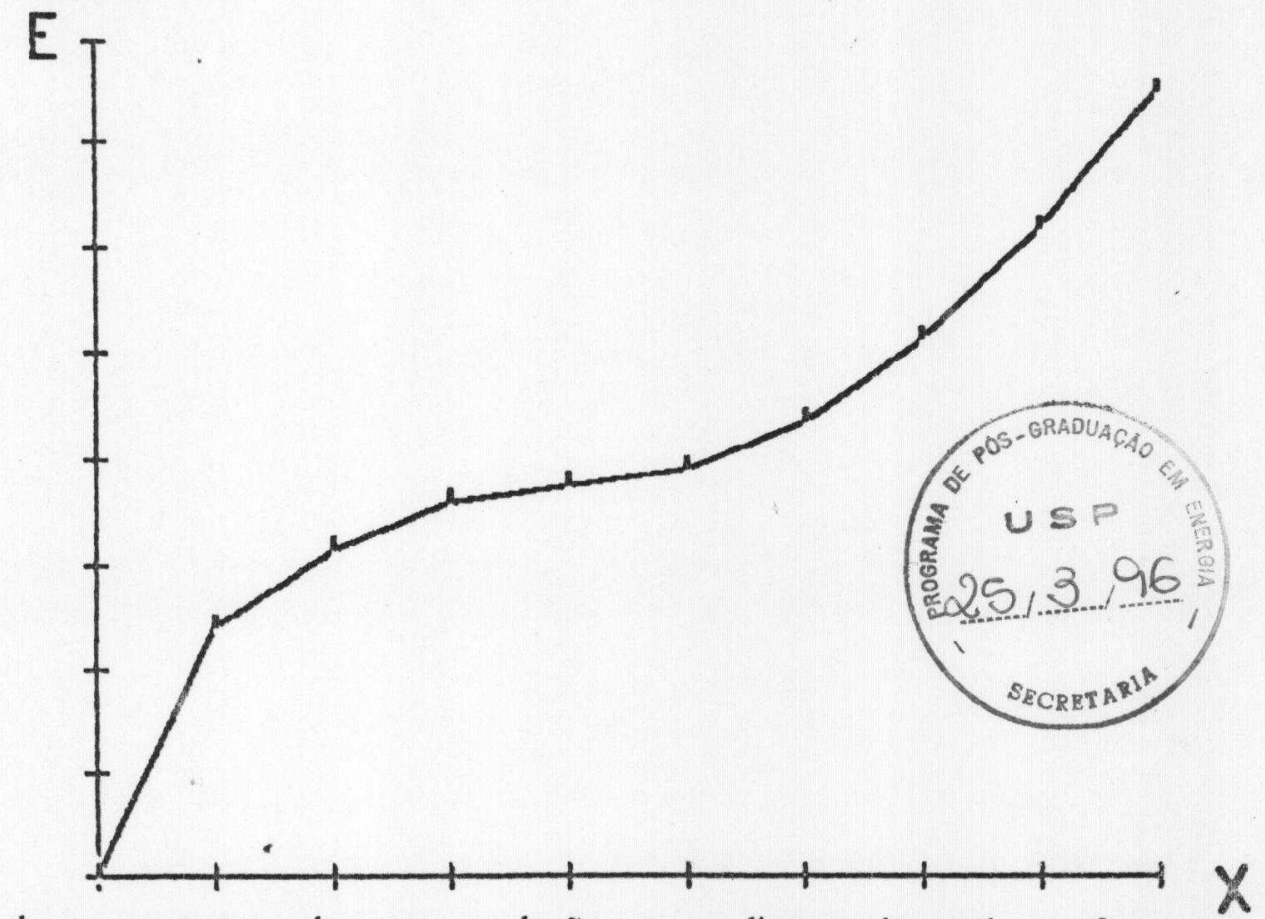

A forma da curva corresponde a uma produção com rendimento de escala, conforme ocorre na indústria de energia elétrica, com relação a maior parte dos fatores empregados.

Curva de Custos - O Custo Total (CT) contábil é formado por uma parcela fixa 
(CF), que não varia comonivel de produção, e outra parcela variável(CV) que é função da quantidade (q) de energia produzida.

$$
\begin{aligned}
& C T=C F+C V \\
& C V=f(q) \\
& C T=C F+f(q)
\end{aligned}
$$

sua expressão gráfica:

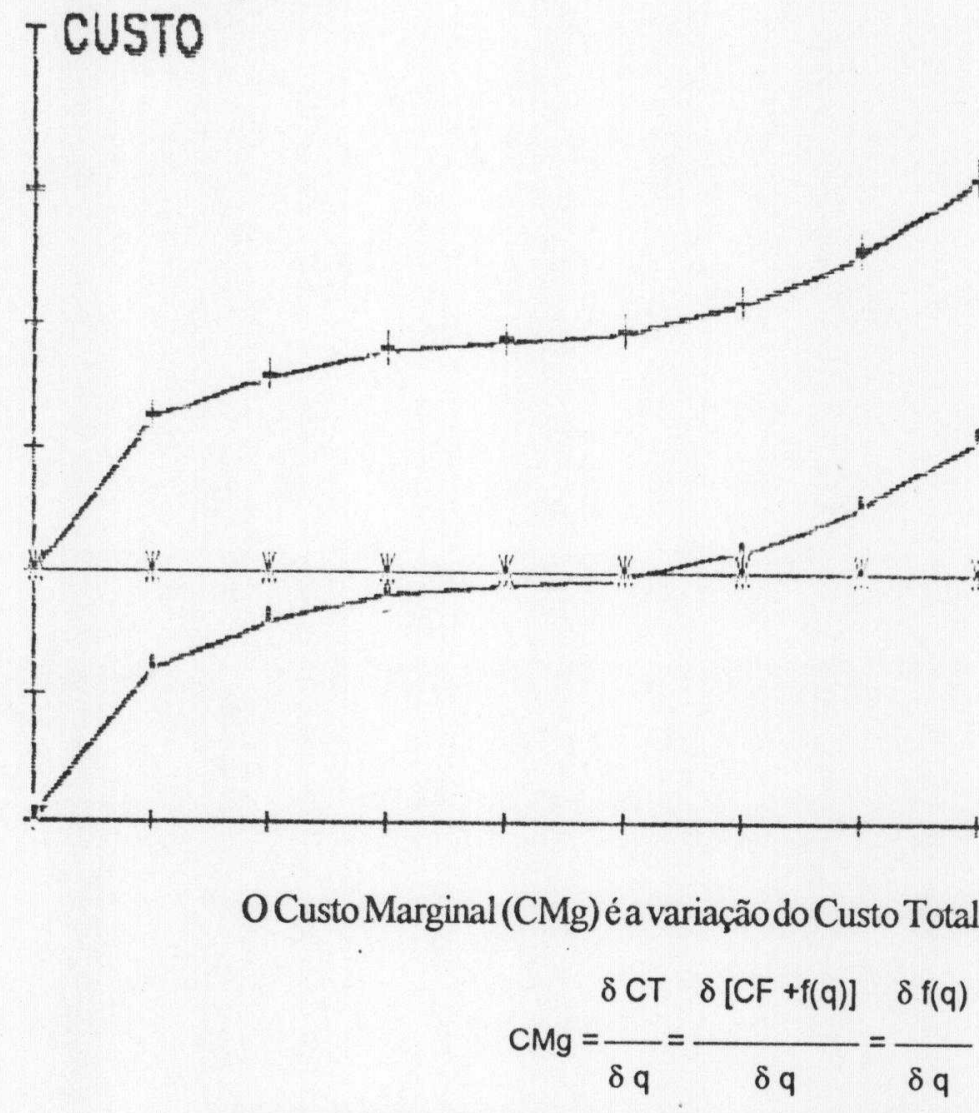

OCusto Total Médio (CT), bem como o Custo Variável Médio(CV), juntamente com o Custo Marginal (CMg), estão representados a seguir:

\section{CISTO}

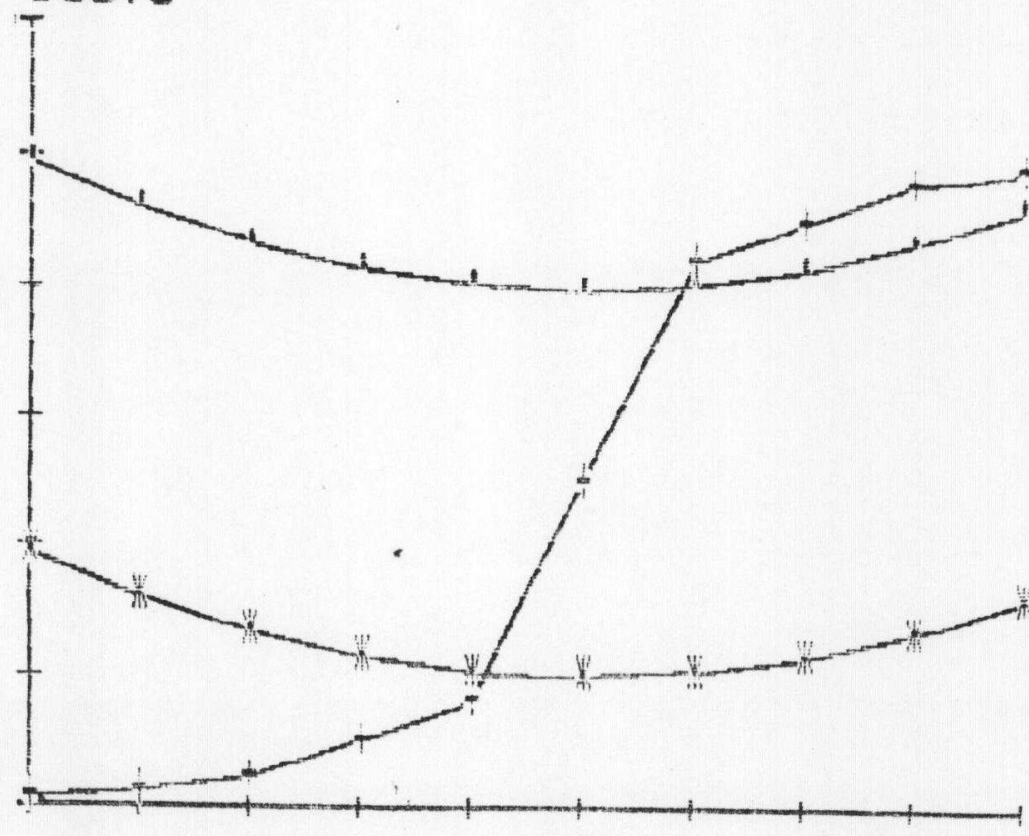

q

\section{(1)}

uantidade produzida.

- CUSTO TOTA HEDIO

t CUSTO MARGIHAL

- CUSTE VARIAVEL MEDIO 


$$
\overline{\mathrm{CT}}=\overline{\mathrm{CF}}+\overline{\mathrm{CV}}
$$

Podemos escrever a partir da equação (5)

$$
\overline{C T}=\frac{C F+f(q)}{q}
$$

A condição ideal da produção se traduz em um custo total médio mínimo, ou seja

$$
\frac{\delta C T}{\delta q}=0
$$

Substituindo a equação (8) na equação (9) e derivando em relação à quantidade q:

$$
\frac{\delta[(C F+f(q)) / q]}{\delta q}=\frac{\frac{\delta f(q)}{\delta q} \times q-1 \times[C F+f(q)]}{q^{2}}=0
$$

Apenas o numerador da fração da equação (10) deve ser igual a zero:

$$
\frac{\delta f(q)}{\delta q} \times q-[C F+f(q)]=0
$$

A partir da equação (11) podemos escrever:

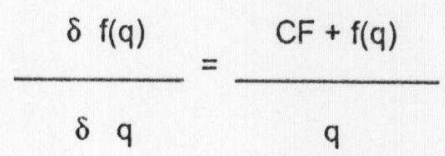

Rclacionada as equações (6) e (8) com a (12), podemos finalmente escrever:

$$
\mathrm{CMg}=\overline{\mathrm{CT}}
$$

ou seja, no equilíbrio da produção, o custo total médio é igual ao custo marginal de curto prazo. (1º́TIMO)

Com relação ao ótimo da sociedade, observa-se uma dificuldade para sua ocorrência no caso brasileiro, pois que uma de suas principais premissas não é atendida - a da livre formação de preços, nos diversos mercados de energia e outros tantos que compõem a economia.

No Brasil os preços dos energéticos não refletem os respectivos custos para a sociedade, por isso os sinais orientadores para o comportamento dos individuos ao consumirem energia, e para a sociedade ao assumir o custo de seu suprimento de energia não são coincidentes. Observa-se neste ponto que os custos que deveriam embasar os preços deveriam ser apurados a partir das decisões mais frequentemente tomadas pela sociedade ao consumir energia; não sendo assim, os preços deixam de ser instrumentos eficazes para a orientação racional dos consumidores. 
Parece mais ou menos certo que o ótimo social em relação à energia estaria vinculado à prática de preços com base em custos marginais, em um ambiente em que as decisões de expansão e os preços dos energéticos fossem decorrentes exclusivamente dos desejos da sociedade, o que não ocorre efetivamente no Brasil, ainda que o estado atuando na ordem econômica através de empresas sob seu controle, como é o caso das estatais do setor elétrico nacional, outorgadas do caráter de concessão sob condições fixadas para a prestação dos serviços públicos de eletricidade, procure interpretar tais anseios servindo de interlocutor entre a sociedade e o setor produtivo.

Para ficar mais claro o raciocínio do ótimo social, observemos o clássico exemplo apresentado por Dessus ${ }^{(7)}$, sobre a procura de uma sociedade por dois energéticos mutuamente substituíveis, diante de preços com base em custos médios e custos marginais. Esse exemplo se desenvolve numa aldeia situada no sopé de uma montanha, onde há uma mina de carvão.

Nessa aldeia há habitantes que podem ser igualmente lenhadores ou mineiros. Esses habitantes iniciam por atender as necessidades energéticas da aldeia com lenha, até que o esforço marginal para a extração da lenha se torne superior ao esforço marginal para extrair carvão. Nesse ponto, numa sociedade onde os recursos de trabalho fossem racionalmente geridos os lenhadores passariam a ser mineiros e a aldeia passaria a ser abastecida com carvão.

Se os preços dos dois energéticos nesse caso refletissem os custos médios, ter-se-ia no ponto em que o custo marginal da lenha supera o custo marginal do carvão, preços da lenha ainda inferiores ao do carvão, e os habitantes da aldeia estariam sendo orientados para o consumo de lenha, com uma absorção de recursos de trabalho maior, sem contudo terem maior satisfação.

Se, por outro lado, os preços dos energéticos refletissem os custos marginais, logo que o custo marginal da lenha supere o custo marginal do carvão, cada individuo perceberia imediatamente esse sinal relativo à utilização dos recursos da sociedade, e comportar-se-ia como se ele próprio a gerisse, escolhendo a variante de consumo mais econômica do ponto de vista social.

Conclui-se assim que o Ótimo Social seria alcançado, pois a satisfação da coletividade seria maximizada, ou seja, as diferenças das satisfações dos agentes seriam minimizadas. ( $2^{\circ}$. ÓTIMO)

As observações de Pareto, acerca do equilibrio da produção e das satisfações da sociedade, têm sido endossadas, ao menos em conceito, atualmente, por governos, agentes financeiros e empresas de energia, embora sua prática nem sempre seja efetivada devido a imperfeições nos modelos econômicos em relação à concorrência perfeita.

Também é oportuno ressaltar o trabalho de Alfred Marshall(vii), que formulou uma teoria geral para o equilibrio da oferta e da procura.

Marshall coloca um fato importante relativo ao comportamento dos preços, ao considerar 
as influências do mercado. As transações, segundo sua colocação, "oscilam em torno de um ponto médio denominado preço de equilibrio: mas a ação dos negociantes, oferecendo um preço e recusando outro, dependerá muito pouco, se é que depende, dos calculos de custo de produção. Eles encaram principalmente a procura atual, de um lado, e, de outro, o estoque já dispontvel da mercadoria."

Tal colocação, analisada no ambiente do Setor de Energia, conduz ao raciocínio de que eventuais excedentes ou déficits de energia deveriam ser negociados em um mercado spot, com tarifas que representam a disposição a cada momento dos consumidores em transacionar disponibilidades.

As tarifas nesse caso não refletiriam necessariamente os custos incorridos no sistema, não se prestando a uma orientação racional aos consumidores a longo prazo.

Uma outra colocação de Marshall diz respeito aos monopólios.

"A divergência entre os interesses individuais e coletivos é, prima facie, menos importante no que se refere a coisas que obedecem a lei do rendimento decrescente, do que no que toca às que se subordinam à lei do rendimento crescente."

Por isso, mesmo levando em conta os males resultantes da distribuição desigual da renda, há, todavia, à primeira vista, motivo para se acreditar que a satisfação total, longe de ser já uma satisfação máxima, seria muito acrescida pela ação coletiva na produção de bens e serviços, sobre os quais atua a lei do rendimento crescente com uma força especial.

Tal colocação, de certa forma, traduz a inconveniência do monopólio na produção de energia e, vista ao par dos monopólios de eletricidade e petróleo no Brasil, torna evidente o peso que recai sobre o Estado como monopolista, ao ter que gerir de forma a aproximar a realidade aos anseios da coletividade.

Nos paises emdesenvolvimento, cuja formação e expansão da indústria de energia elétrica se deu após a ocorrência nos países que foram palco da Revolução Industrial, conforme anteriormente comentado, o monopólio da produção e distribuição da energia é frequentemente observado.

Sua prática, normalmente pelos governos daqueles paises, foi embasada em modelos econômico-financeiros que consideram os custos incorridos no sistema energético, como elemento fundamental para a fixação das tarifas.

Emalguns casos, as tarifas são iguais aos referidos custos, em outros são referenciadas aos mesmos, sofrendo porém a influência de fatores diversos tais como subsídios, sobrepreços ou defasagens monetárias.

As leituras e pesquisas às obras citadas neste primeiro item foram realizadas com o intuito de conhecer e ressaltar características das teorias de preços, buscando identificar traços que possam sugerir fundamentos para a grande questão que se coloca atualmente no campo da energia, 
qual seja, a necessidade de se ter racionalidade e eficiência na oferta e na utilização final da energia.

Ao completar essa busca, podemos ressaltar as seguintes conclusões, relativamente ao objetivo pelo qual foi realizada:

- Os dois enfoques da formação de preços, identificados nas teorias clássicas, quais sejam: a formação resultante dos custos de produção, os preços naturais, e a formação resultante das relações entre a oferta e a demanda, os preços de mercado, explicam os mecanismos de preços de forma geral, e, são aplicáveis ao caso da energia, em qualquer que seja a organização da atividade de produção, distribuição e consumo de energia. Os preços, portanto, podem ser veículos para sinais básicos em uma política energética.

- Na escola neoclássica, a teoria de equilibrio formulada por Pareto, representa a base conceitual sistematizada para a racionalidade da oferta e do consumo de energia, esta última pode ser vista como uma alternativa formal para a expansão relativa da oferta, qual seja, atender-se maior número de consumidores ou maior quantidade de energia útil, sem a expansão física do sistema.

- Ao analisar a conservação de energia clétrica sob o ponto de vista do $2^{\circ}$. ÓTIMO, concluimos que sempre que o custo social da conservação for inferior ou igual ao custo social da expansão da oferta, aquela primeira deve ser priorizada.

- Considerando-se um determinado padrão de tecnologia da oferta, os custos incorridos com a ação de conservação representam a contrapartida para um aumento da eficiência do consumo, e estes, do ponto de vista social, se forem menores do que o beneficio da energia conservada, tão logo identificados resultam na necessidade para a sociedade em buscar nova posição de equilibrio ( $2^{\circ}$. ÓTIMO), pois, a posição anterior já consistirá num desequilibrio.

\section{2 - BASES DE CUSTOS PARA AS TARIFAS - METODOLOGIAS DE CÁLCULO}

A partir da discussão sobre as teorias de preços e as conclusões apresentadas no Item 1, procuramos agora buscar uma maior concentração no caso da energia elétrica no Brasil, complementando a conceituação já apresentada com a formulação da formação de preços atualmente adotada, para posteriormente, discutirmos os resultados da prática tarifária atual, tendo em mente o que preconiza o modelo tarifário e o que na realidade se verifica.

A conjugação das conclusões dos Capítulos I e II consistirá um conjunto de fundamentos e condições para a formulação de uma proposta de tarifas orientadas para a eficiência do consumo, o que é objeto, do Capitulo III. 
Os custos incorridos nos sistemas de produção, transmissão e distribuição de energia, conforme a teoria microeconômica, podem ser classificados em dois grupos:

a) Custos Médios

b) Custos Marginais.

Os custos médios por sua vez podem ser subclassificados em dois grupos:

a.1) custos médios de ativos ${ }^{(8)}$

a.2) custos médios de passivos ${ }^{(9)}$.

Em geral as tarifas dos diversos energéticos são fixadas com base nessas referências de custos, embora existam outros fatores também considerados, tais como: a oferta ea procura, num ambiente de concorrência, a política econômica e a politica de preşos públicos em ambientes de monopólio ou de prestação de serviços públicos em regime de concessão; e, mais recentemente tem-se recomendado a consideração da política energética em harmonia com a fixação de preşos dos energéticos ${ }^{(10)}$.

Considerando as funções sócio-econômicas do suprimento de energia à sociedade, bem como os múltiplos e variados efeitos relacionados comos preços praticados em sua comercialização, foram consagrados alguns principios básicos para as tarifas, particularmente para aquelas fixadas sob controle do estado, em regime de concessão ou monopólios:

Neutralidade - cobrar de cada consumidor ou grupo de consumidores semelhantes, os custos efetivamente incorridos em seu fornecimento.

Equitatividade - preços equivalentes, sem favorecimentos ou penalizações entre consumidores.

Eficácia - refletir com propriedade os custos incorridos ao longo do sistema e ao longo do tempo, sugerindo racionalidade econômica para as ações dos consumidores ao demandarem energia.

E, considerando as mais recentes preocupações com a harmonia desejável entre as tarifas e a política energética, propõe-se um princípio adicional:

Coerência - refletir coerentemente os objetivos da politica energética, sugerindo eficiência individual e coletiva no consumo dos diversos energéticos.

No presente capítulo apresenta-se uma análise das bases de custos, e, posteriormente será discutida a orientação das tarifas para a eficiência do consumo.

Não serão discutidos detalhes de aplicação de cada metodologia, procurando-se evitar a particularização de casos, porém,serão enfocados os aspectos conceituais das mesmas. (vii) 


\section{a) Tarifas a Custos Médios}

A análise em questão emprega o exemplo do Setor Elétrico Brasileiro, onde o fornecimento de energia elétrica é tido como um serviço público, com a exploração dos recursos naturais e do mercado sendo realizada através de empresas concessionárias, e, com as tarifas sendo fixadas pelo poder concedente, a República Federativa do Brasil, representada pela administração direta do governo federal.

Nesse exemplo, a base de custos médios dos ativos está legalmente estabelecida para referência do nivel tarifário, entretanto, a estrutura das tarifas corresponde à referência de çustos marginais.

\section{a.1) Base de Custos dos Ativos}

A base de Custos dos Ativos é apurada a partir dos registros históricos de todas as aplicações de recursos de capital, doações e subvenções no sistema de energia em questão, ou a partir de projeções daqueles registros.

Geralmente há um plano de contas que estabelece classificação específica e detalhada para cada aplicação ou formação de recurso, entretanto, na composição do Custo Total dos Ativos podem ser relacionados os seguintes principais componentes:

Remuneração do Investimento - que se destina a proporcionar recursos para a remuneração de todo o capital empregado na empresa de energia, envolvendo o capital próprio - dos acionistas, e o capital de terceiros - empréstimos e financiamentos.

Depreciação - que se destina a prover recursos para compensar as perdas de valor dos equipamentos, instalações e materiais, ou seja, que tem função e existência temporária, e, em gastos cuja alocação é diferida no tempo.

Despesas de Exploração - que se destina a prover recursos para as despesas com pessoas, materiais de consumo, serviços de terceiros, combustiveis, taxas, enfim todos os gastos com O\&M.

É oportuno ressaltar que em serviços de eletricidade cuja realização se dá por concessão do estado, é comum encontrar-se mais um item de custo:

Reversão -"que se destina a prover recursos para a indenização do concessionário pelos bens e instalações existentes ao final do periodo de concessão, ou em outro momento em função do interesse público.

Esses componentes são calculados para um determinado periodo de tempo, por 
exemplo um ano, podendo ser inclusive um periodo prospectivo. A soma dos mesmos resulta no custo total dos ativos, que deve ser coberto com a receita tarifária no periodo determinado.

As tarifas, ao final, resultam da equação que relaciona o mercado e o custo total:

$$
t(\text { média })=\frac{\text { Ctotal }}{M}
$$

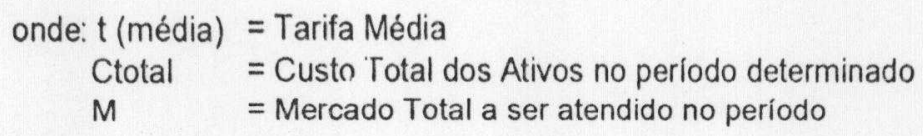

As relatividades entre tarifas de diversas classes de consumo são consideradas previamente estabelecidas, não sendo explícita a alocação de custos na base conceitual dessa metodologia.

\section{a.2) Base de Custos dos Passivos}

A base de Custos dos Passivos é apurada a partir da programação de pagamentos relativos à remuneração e retorno dos recursos de capital investidos na empresa, além dos gastos com O\&M. Os componentes da base de custos dos passivos são:

Remuneração do Capital Próprio - que se destina a remunerar o capital dos acionistas, aplicado na empresa.

Retorno do Capital Próprio - que se destina a restabelecer a liquidez do capital dos acionistas, permitindo-lhes a perenização do negócio, através da reinversão em bens e equipamentos, ou, a cessação do mesmo, quando de seu sucateamento.

Encargos Financeiros de Empréstimos e Financiamentos - que se destina a formar recursos para suportar custos incorridos no determinado período de tempo considerado no cálculo das tarifas, pela utilização de capital de terceiros.

Amortização - que se destina ao retorno do capital de terceiros aplicado na empresa.

Despesas de Exploração - que se destina a prover recursos para O\&M.

Também no caso da base de custos dos passivos, não existe alocação econômica de custos entre as diversas ćlasses de consumidores ou tipos de produtos do sistema energético (niveis de tensão, tipos de combustiveis, etc). Cita-se como exemplo as tarifas da usina Itaipu, por ser a energia comercializada em grosso junto a empresas que por sua vez a distribuem aos consumidores finais. 


\section{b) Tarifas a Custos Marginais}

A formação dos preços de energia, com base em custos marginais, conceitualmente, significa adotar como referência de valores, os custos que se espera incorrer gerindo o sistema para atender a uma unidade marginal de energia demandada, em determinado ponto do sistema e determinado instante de tempo.

A premissa da identificação espacial e temporal do atendimento, bem como a identificação dos custos decorrentes das gestões que o precedem, implica na necessidade de que tal metodologia incorpore uma razoável alocação dos custos incorridos tanto no sistếma quanto aos gestores e usuários do mesmo.

Considerando a situação ideal em que o sistema elétrico como um todo está adaptado às necessidades do mercado, a decisão de se atender a uma demanda marginal acarretará um custo, o qual dependerá da gestão adotada: a expansão do sistema, ou um incremento na operação com a configuração existente. Na situação ideal do sistema adaptado à carga, os custos correspondentes a qualquer das gestões serão iguais entre si.

Naturalmente, as metodologias de cálculo dos custos associados a uma e outra gestão para atendimento da demanda adicional, são diferentes entre si na medida em que uma considera investimentos na expansão dos segmentos do sistema, necessários ao atendimento marginal, e a outra gestão considera somente os acréscimos de custos de operação e manutenção, de combustivel para geração térmica e de perdas, além do custo inerente a uma maior probabilidade de déficit, ao se atender a um mercado maior com a mesma configuração do sistema.

As composições básicas do custo marginal de expansão, também denominado custo marginal de longo prazo, e do custo marginal de operação, também denominado custo marginal de curto prazo, são as seguintes:

Tabela 3 - Composição dos Custos Marginais de Expansão e Operação

Custo Marginal de Expansão

(Longo Prazo)

Custo do Investimento no $1^{\circ}$.ano

Variação do Custo Anual de O\&M

Variação do Custo Anual de Combustivel

Variação do Custo Anual de Perdas

Variação do Custo Anual de Déficit
Custo Marginal de Operaçāo

(Curto Prazo)

Variação do CustoAnualde O\&M

Variação do Custo Anual de Combustível

Variação do Custo Anual de Perdas

Variação do Custo Anual de Déficit

A diferença entre os custos marginais de expansão e de operação consiste somente na consideração da parcela relativa ao custo anual $\left(1^{\circ}\right.$. ano) do capital investido, sendo incluida no cálculo do custo marginal de longo prazo, e não incluída no calculo do custo marginal de curto prazo. Observamos, entretanto, que para as redes elétricas, aquela composição do custo exclui o custo anual de combustivel. 
As metodologias de cálculo dos componentes dos custos marginais diferem segundo os segmentos do sistema elétrico, devido ao fato de que a natureza da expansão e da operação dos mesmos, bem como os processos de gestão dos quais originam os custos em si, são diferentes em cada segmento do sistema elétrico.

Observamos também que fundamentalmente as três metodologias em tela apresentam bases conceituais similares para a composição dos custos, ao menos em termos de natureza dos componentes. A diferença principal está na alocação espacial e temporal de custos, presente com maior propriedade na metodologia de custos marginais.

Entende-se mesmo, ser a alocação de custos o mais forte argumento a favor da metodologia de custos marginais ${ }^{(1)}$. Apresenta-se nos itens b.1 e b. 2 a seguir, um detalhamento da análise da metodologia em questão.

\section{b.1) Análise dos Componentes dos Custos Marginais do Sistema}

As metodologias de cálculo de cada componente dos custos marginais diferem entre sí de acordo com a própria natureza de cada segmento do sistema elétrico, e, de acordo com os respectivos processos decisórios de expansão e operą̧ão daqueles segmentos.

Essas metodologias são definidas em função dos processos de gestão dos segmentos do sistema, e portanto, os custos marginais resultantes refletem diretamente as decisões relativas à expansão e à operação do sistema ${ }^{(\mathrm{ix})}$.

\section{Custo do Investimento no $1^{\circ}$. Ano}

Refere-se ao custo anual do capital total a ser investido na expansão fisica dos segmentos do sistema elétrico, decorrente da decisão de aumentar a capacidade de atendimento. Esse contempla a remuneração e a recuperação do capital investido. $O$ cálculo desse componente pode ser feito de duas formas: (a) a partir dos desembolsos previstos para os programas de obras futuras; ou, (b) a partir de séries históricas de partes componentes de obras, projetando-as em termos de quantidades fisicas, e, atribuindo a essas projeções os custos esperados. As expressões matemáticas referentes a essas duas formas de calcular estão apresentadas no Anexo I.

\section{Variação do Custo Anual de Operação e Manutenção}

O custo anual de operação e manutenção refere-se às despesas com pessoal, material, serviços e outras necessárias ao funcionamento do segmento do sistema em questão. Excluem-se os combustiveis para geração térmica. 
A variação do custo anual aqui mencionada, significa o valor a ser agregado aos custos de O\&M atualmente incorridos, com a entrada em operação das novas obras.

Esse valor a ser agregadoé calculado com base nos custos verificados historicamente, pois ainda não se dispoem de metodologias que melhor estimem os custos a serem incorridos; e, mesmo porque esses custos dependerão das condições em que se encontra a operação do sistema no momento de entrada das novas obras, da mudança de escala de funcionamento e também da evolução tecnológica.

No caso das redes elétricas, esses custos são agregados sob a forma de percentuais aplicados sobre o custo do investimento. Esses percentuais são apurados a partir de séries históricas.

O Anexo II apresenta os valores que têm sido adotados nos cálculos deste componente de custo, para cada segmento das redes elétricas.

Variação do Custo Anual de Combustiveis

O custo anual de combustíveis refere-se à despesa anual com combustiveis para geração térmica, decorrente do incremento de atendimento do sistema. A variação desse custo é estimada através de simulações da operação do parque gerador interligado, com a configuração existente e com a configuração prevista para o periodo imediatamente subsequente ao momento da decisão do atendimento adicional, fazendo-se o produto das quantidades de energiageradas por fontes térmicas pelos respectivos consumos específicos de combustiveis e preços dos mesmos, esperados para o periodo de realização.

\section{Variação do Custo Anual de Perdas}

O custo anual de perdas refere-se à parcela percentual de custo que é acrescentada, com o mesmo peso do custo unitário de desenvolvimento, para compensar a eletricidade que é dissipada no funcionamento dos próprios equipamentos do sistema elétrico.

Essa parcela percentual, também estimada a partir de simulações da operação do sistema com as configurações existente e futura, é apurada com base em cálculos de fluxos de potência do sistema elétrico.

Observa-se, entretanto, que no cálculo dos custos marginais de redes essa componente não é considerada, sendo porém incluída na composição dos custos marginais totais associados a um atendimento adicional em cada nível do sistema, conforme será comentado no próximo item. No cálculo dos custos marginais de produção, o custo de perdas é originalmente considerado.

\section{Variação do Custo Anual de Déficit}

O custo anual de déficit refere-se ao custo decorrente de interrup̧̧̃es de longa duração, até certo ponto administráveis no espaço e no tempo considerada a configuração do sistema resultado da gestão empreendida. 
Esse custo pode ser estimado a partir de uma análise do efeito de uma provável falta de energia elétrica para a economia em seus diversos setores, o custo assim calculado é denominado custo explicito de déficit. Pode também ser estimado a partir de referências implícitas ao próprio sistema, sendo que atualmente no Brasil se tem calculado o custo do déficit somente para energia, adotando como referência a diferença entre o custo esperado de geração térmica e o custo marginal de energia, considerando-se assim o custo de déficit como uma constante ${ }^{(12)}$.

Em realidade, o custo marginal de déficit pode ser variável com a profundidade do déficit. Define-se assim o custo marginal de déficit como uma função discretizada por faixas.

A variação do custo anual de déficit corresponde à diferença verifícada no cálculo do custo de déficit para duas configurações do sistema elétrico, similarmente às demais componentes.

Há um questionamento quanto à inclusão desse custo na composição do custo marginal, pois, em realidade o déficit corresponde a algo não atendido; mas, há também um contra-argumento, qual seja o de que sua inclusão se presta a prover recursos para que o déficit possa ser administrado. E, prover recursos na proporçâo do valor que representa a carência de energia no curto prazo, pois, é nessa proporção que serão os custos das soluções empregadas na administração do déficit.

\section{b.2) Análise da Formação dos Preços com base nos Custos Marginais do Sistema}

Essa formação de preços e consequente alocação de custos é pautada dentro dos três princípios básicos anteriormente citados:a neutralidade, a igualdade e a eficácia.

A neutralidade requer que a sistemática de cálculo das tarifas considere o custo especifico de cada tipo de atendimento, não permitindo a transferência implícita de custo entre os tipos diferentes de consumo.

A igualdade exige que para cada conjunto de consumidores de um determinado tipo seja praticada uma única tarifa.

A eficácia, que garante a sinalização para os consumidores relativamente aos custos incorridos pelo sistema nos diferentes instantes de tempo e locais de atendimento.

A formação dos preços dos fornecimentos é feita em duas componentes uma de energia e outra de potência, sendo que esses dois entes fisicos são considerados no faturamento.

A componente de energia é obtida pelo somatório dos produtos das parcelas, dos custos marginais de expansão do parque gerador e da rede de interconexão alocadas à energia, pelos fatores de perda de energia, a partir da rede de interconexão até o nível de cada fornecimento nos horários diferenciados considerados na estrutura tarifária. 
A estrutura tarifária atualmente praticada no Brasil apresenta duas faixas de horários diferenciadas, quais sejam, ponta e fora da ponta de carga do sistema. A ponta, compreendendo três horas consecutivas dentro do periodo das 17 às 21 horas, e, sendo definida em função do carregamento do sistema elétrico em cada local; fora da ponta, compreendendo todas as demais horas.

A expressão a seguir ilustra o cálculo do custo de energia:

$$
C_{u}^{E}=\left(1+\tau_{u}\right) \times E_{u} \times\left(\mu_{u}+\mu_{u}^{A 0}\right)
$$

onde:

$\mathrm{C}_{\mathrm{u}}^{E}=$ custo de energia incorrido em determinado fornecimento marginal, no horário u

$\tau_{u}=$ perdas de energia desde a rede de interconexão até o nivel do fornecimento, no horário u

$E_{\mathrm{u}}=$ consumo de energia correspondente ao fornecimento em queståo no segmento horário $u$

$\mu_{u}=$ componente de energia do custo marginal de expansăo do parque gerador, no horário u

$\mu_{\mathrm{u}}^{\wedge} \mathrm{O}=$ componente de energia do custo marginal de expansăo da rede de interconexăo, no forário u

A componente de potência é obtida a partir da somatória dos produtos das parcelas dos custos marginais do parque gerador, da rede de interconexão alocadas à potência, e, dos custos marginais totais das redes de repartição e distribuição, pelas responsabilidades de potência associadas aos diversos tipos de atendimento, e, pelos fatores de perdas de potência, no sistema, desde o nível dos atendimentos até o nivel de cada segmento do sistema a montante do ponto em questão.

A expressão a seguir ilustra esse cálculo:

$$
C_{u}^{p}=\sum_{1} C_{u}^{P_{1}}=\sum_{1} R_{u}^{1} \times \sigma^{\prime}
$$

onde:

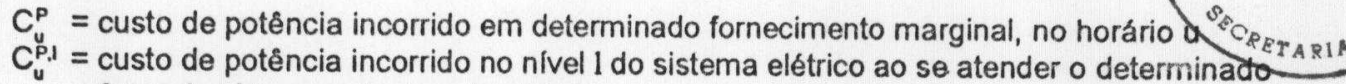

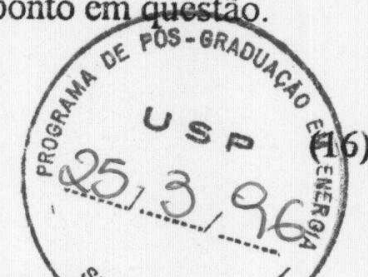
fornecimento marginal, no horário $u$

$R_{u}^{\prime}=$ responsabilidade do determinado fornecimento, nos custos de potência incorridos no nível 1, no horário u

$\sigma^{\prime}$ = custo marginal de potência, no caso de rede de interconexão, e, custo marginal total, no caso das demais redes elétricas correspondentes aos niveis 1 .

Nota: a responsabilidade $\mathrm{R}^{\mathrm{l}}$ é um fator adimensional, calculado a partir de valores esperados para o comportamento dos consumidores, e, engloba as perdas de potência que ocorrem ao longo do sistema.

As componentes assim obtidas, constituem-se em referência para cada tipo de fornecimento, e, denominam-se custos marginais dos fornecimentos-tipo. Existindo vários tipos distintos de fornecimentos em determinado nível, e, sendo necessária a aplicação de uma única tarifa para todos os tipos, faz-se o ajuste de uma tarifa de referência, que mais se aproxime dos custos marginais dos fornecimentos-tipo do determinado nível.

O gráfico ápresentado no Anexo III ilustra esse ajuste.

Ao completar a discussão das metodologias de cálculo de tarifas, podemos concluir que aquela com base nos custos marginais está impressa de uma forte preocupação com a alocação de custos, segundo a responșabilidade dos tipos de consumidores, resultando em estruturas tarifárias 
mais adequadas à sinalização tarifária.

O nivel de receita necessário ao desempenho financeiro da indústria de energia elétrica pode resultar diferente daquele dos custos marginais; a formação de preços com base no passivo pode representar com maior exatidão essa necessidade. E os preços formados com base nos ativos, representam referência econômica similar em conceito às outras duas, mas desprovida de ligação sistematizada entre as condições da expansão e operação do sistema e a expressão resultante do custo médio.

É também oportuno observar que a base de custos médios contábeis, conforme foi adotada na Brasil desde a década de 30 até atualmente, representa uma razoável experiência da prática de tarifas a custos contábeis históricos. Nesse periodo podemos constatar fases de realismo do nível tarifário, bem como fases quando as tarifas foram fixadas abaixo dos respectivos custos incorridos; posteriormente verificaremos essas fases em detalhes.

Mas, o principal fato nessa experiência está nos procedimentos legais instituidos para o cálculo da expressão contábil dos custos dos ativos; os mesmos não permitem agregações aos valores dos ativos, decorrentes de desvalorização monetária, na proporção real e ao tempo justo, resultando em subvalorização do custo medio apurado.

Um exemplo dessa prática está na recente decisão do Conselho Nacional de Energia, formado pelos Ministros da Economia, Minas e Energia, Transportes e Comunicações, que em sua Resolução número 20, de 09 de abril de 1992 determinou estudos no sentido de que os resultados das equações tarifárias (produtos das tarifas pelos mercados iguais aos custos do serviço) somente considerem a complementação da correção monetária de 1990 (instituida pela Lei $n^{\circ}$ 8200/91 exatamente por se ter constatado a insuficiência e irrealismo da correção monetária oficial reconhecida pelo governo naquele ano), em cinco parcelas anuais sendo a primeira em 1991.

Embora a nível de recomendação para estudos, o Departamento Nacional de Águas e Energia Elétrica - DNAEE, órgão que representa o poder concedente com competência para aprovar os demonstrativos de custos dos concessionários, já decidiu pela implementação de tal sugestão, através de sua Portaria n $^{\circ}$ 114/92, de 10 de abril de 1992.

O motivo para essa prática provavelmente está ligado à tendência do governo em conter a elevação dos custos das empresas estatais e por consequência conter também a evolução dos preços da energia elétrica.

Veremos na sequência da presente dissertação que essa tendência de contenção do nivel tarifário está resultando num grande subsidio do Setor Elétrico aos demais setores da economia, despotencializando sua geração interna de recursos e abalando fortemente sua estrutura de capital. 


\section{CAPÍtUlo II}

\section{PRÁTICA TARIFÁRIA ATUAL NO SETOR ELÉTRICO BRASILEIRO}

\section{1 - O MODELO TARIFÁRIO - SÍNTESE CRONOLÓGICA}

\section{1 - CONSIDERAÇÕES GERAIS}

O modelo tarifário de energia elétrica brasileiro quando do inicio dą̧organização da indústria de eletricidade no Pais, ao final do século XIX, baseava-se em referências extrinsecas ao conjunto de custos e caracteristicas do sistema elétrico para estabelecer os valores das tarifas; já no século XX, com o advento do Estado Novo, em 1930, seu arcabouço legal foi profundamente modificado, passando a adotar os custos médios dos ativos das empresas de eletricidade como base para o estabelecimento das tarifas.

Encontra-se desde 1982 em reestruturação, com a implantação da base de custos marginais para suportar a estrutura das tarifas, embora o nivel de preços continue sendo legalmente orientado pelos custos médios ou por outros objetivos estratégicos do governo federal, como é o caso do combate à inflação.

Devido às dimensões do sistema e à extensão geográfica das áreas que necessitavam ser eletrificadas, bem como aos vultosos investimentos requeridos à expansão do sistema, foi organizado um regime de concessões através do qual o monopolista dos recursos hídricos e do direito de prestar servicos públicos de eletricidade, que é a União (República Federativa) representada pelo governo federal, concede o direito de realizar obras de geração, sejam elas aproveitamentos de recursos hídricos ou usinas termelétricas, obras de transmissão ou distribuição, bem como o direito de comercializar a energia produzida.

Embora com o regime de concessões sejam transferidos os direitos de produzir, distribuir e comercializar, o poder concedente mantém o controle da qualidade do serviço prestado pelo concessionário, bem como das condições econômico-financeiras da concessão. Assim, com a premissa de que os recursos de capital necessários ao sistema de oferta de energia devem se originar em partes iguais de três fontes, quais sejam: dos proprietários do negócio, das tarifas e de terceiros, o modelo tarifário considera que as tarifas devam legalmente ser formadas conforme descrito no Capitulo I, desta dissertação, e, devem ter seus niveis monetários resultantes da apuração de custos conforme aquela descrição. 
A prática tarifária no Setor Elétrico do Brasil tem se revelado com resultados opostos àqueles previstos na teoria do monopólio formulada pelos pensadores da escola clássica, porquanto verifica-se no País um dos mais baixos níveis tarifários do planeta, conforme mostra a Tabela 4, ao mesmo tempo em que se verificam mais frequentemente periodos de sobra do que de déficit de energia, conforme mostra a Tabela 5, ao contrário do que teoricamente se prevê que ocorra num monopólio, conforme as teorias clássicas comentadas anteriormente.

Certamente essa inversão de resultados se deve ao estado ser o monopolista, com seus preceitos de garantia da infraestrutura básica de energia elétrica, com base em projeções de necessidades de expansão que pecam por serem demasiado otimistas, e, por manter artificialmente os preços praticados no mercado abaixo dos preços naturais, com a tentativa de evitar realimentações no processo inflacionário.

O sistema elétrico assim gerido representa um elevado custo para a sociedade, porquanto os critérios de sua expansão consideram uma garantia de $95 \%$ de atendimento dentre as possibilidades de afluências hidráulicas ao sistema, garantia essa quantificada com base na simulação de 2000 possibilidades distintas de afluências em determinado periodo, resultando na necessidade de grandes programas de obras, que requerem investimentos anuais, da ordem de 2 a $3 \%$ do Produto Interno Bruto - PIB anual.

Por outro lado, o artificial baixo nivel tarifário resulta em problemas de fluxo de caixa e consequentes incapacidades de amortização dos financiamentos e remuneração do capital próprio; a gestão financeira nessa condição tem lançado mão da rolagem das dividas, que em sua maior parte são em moedas externas, ampliando sobremaneira o já elevado custo social dos empreendimentos no sistema elétrico.

Essa situação nos transmite uma impressão de ineficiência, cujo custo econômico e social é elevado, cuja minimização é fundamental para dar prosseguimento à evolução de um sistema eletroenergético auto sustentável, como é preconizada a hidreletricidade no Brasil ${ }^{(13)}$

No propósito da presente dissertação, o entendimento das relações de causa e efeito dos processos decisórios que se concatenam na gestão da expansão do sistema, ilustrado com a prática das tarifas, permitirá a caracterização de um contexto prático, em complementação ao teórico, anteriormente tratado, formando o ccnário básico onde se insere a proposta de orientação das tarifas para a eficiência, a ser aṕresentada no Capitulo III, numa tentativa de propor um mecanismo que possa servir como coadjuvante no incremento da eficiência do conjunto oferta-consumo.

Portanto, apresentam-se discussões sobre as relações de causa e efeito dos processos decisórios da gestão da expansão do sistema, contemplando a projeção da demanda, o planejamento da 
expansão e a construção das obras, procurando ressaltar a influência das tarifas em cada uma delas.

Entretanto, antes de apresentar tais discussões, será apresentada uma sintese cronológica da evolução do modelo no setor elétrico no Brasil, objetivando caracterizar mais completamente o contexto da prática tarifária e assim conferir maior significado à influência da mesma nas relações acima citadas.

\section{2 - SÍNTESE CRONOLÓGICA ${ }^{\text {(vii) }}$}

A história da comercialização da eletricidade no Brasil teve seu ínício em 1883 , quando o Imperador D. Pedro II inaugurou uma usina termelétrica a carvão, de $52 \mathrm{~kW}$, e um sistema de iluminação pública na Cidade de Campos, no Rio de Janeiro.

Nesse mesmo ano começou a operar a primeira hidrelétrica no País, a usina do Ribeirão do Inferno, no Município de Diamantina, então província de Minas Gerais; a usina tinha barragem de $5 \mathrm{~m}$, duas máquinas Gramme de $8 \mathrm{CV}$ e $1500 \mathrm{rpm}$ a corrente continua; a energia era utilizada a $2 \mathrm{~km}$ de distância, para movimentar duas bombas de desmonte a jato d'água, em terreno diamantífero, e também para iluminação.

No final do século XIX ocorreu então o início do Setor Elétrico Brasileiro, com os primeiros empreendimentos e com a sua organização calcada em tecnologias e modelos estrangeiros.

Sua organização foi inspirada nos moldes das ferrovias norte americanas, cuja filosofia se baseia no princípio de concessões para a exploração dos serviços; pois que, desde aquela época, os recursos hídricos no País eram propriedade do império; e, com o estabelecimento de tarifas que proporcionassem rentabilidade garantida às empresas e a seus acionistas, com determinada proteção aos usuários.

As concessões naquela época cram feitas por intermédio das autoridades municipais, sendo que as primeiras grandes empresas concessionárias foram multinacionais, tais como o Grupo Light que montou os concessionários The São Paulo Railway, Light And Power Co. Ltd., em 1899, e, The Rio de Janeiro Tramways, Light And Power Company Limited em 1905, que exploraram os serviços públicos de energia elétrica, respectivamente nas maiores metrópoles do País; e o Grupo norte americano Electric Bond And Share Co. (EBASCO), que fundou a American Foreign Power Company (AMFORP) para atuar no interior do Estado de São Paulo.

Em 1903, foi promulgada uma lei bastante genérica que disciplinava a utilização de energia elétrica no País; foi a primeira Lei Federal sobre a energia elétrica, a qual autorizava o governo 
federal a promover, por via administrativa ou mediante concessão, o aproveitamento de força hidráulica para os serviços federais, facultando o emprego do excedente na lavoura, na indústria ou outros fins.

Para dar maior garantia à rentabilidade dos empreendimentos, como princípios de seu modelo, as tarifas eram reguladas pela cláusula ouro, onde parte da energia era paga em função da cotação internacional do metal, sendo a parte complementar regulada em função das próprias despesas operacionais incorridas no fornecimento de eletricidade.

Tinha-se, portanto, a fundamentação do modelo, calcado no princípio de concessão, dentro de uma total descentralização e privatização da iniciativa, garantindo a rentabilidade dos investimentos como forma de desenvolvimento estável e continuo.

Comoadvento do Estado Novo, na década de trinta, cresceu bastante a regulamentação do Setor, acompanhando o contexto do desenvolvimento industrial, com o intervencionismo do Estado e o nacionalismo como fundamentos básicos.

Foi então revogada a cláusula ouro, e foi aprovado um Código de Águas, que regulamentava as concessões, restringindo-as a brasileiros ou empresas organizadas no País, embora ressalvava os direitos adquiridos das multinacionais; quanto ao modelo tarifário, foi instituido o princípio do custo histórico, custo médio contábil e do serviço pelo custo.

A evolução do Setor Elétrico Nacional foi então ocorrendo com uma crescente centralização, com a constituição de concessionários estatais, os primeiros vinculados aos governos estaduais, e mais outros vinculados ao governo federal; isso ocorreu quando os concessionários de iniciativa privada, que desde o inicio dominavam os serviços públicos de energia elétrica, não mais respondiam ao ritmo de crescimento do mercado, devido a injunções políticas, problemas econômicofinanceiros das concessões, e, devido à remuneração dos investimentos basear-se em valores históricos dos investimentos, limitando a capacidade de reinvestimentos frente às demandas crescentes.

Em 1974, foi introduzida a equalização tarifária, com uma câmara de compensações denominada Reserva Global de Garantia - RGG, cujo objetivo era praticar-se um mesmo preço em todo o território nacional, e, possibilitar-se o fornecimento em regiões onde os custos eram elevados.

Então, estabaleceu-se um subsidio cruzado entre concessões, porém mantendo-se a garantia de remunerações mínimas de $10 \%$ e máximas de $12 \%$ a.a. Os eventuais excedentes de remuneração acima de $12 \%$ passaram a ser compulsoriamente recolhidos à RGG para formar o fundo cujos recursos eram transferidos aos concessionários com remuneração inferior à $10 \%$, e no máximo até este limite. 
A partir de 1978, a fixação de tarifas passou a ser feita mediante prévia autorização da Secretaria de Planejamento da Presidência da República, passando a ser considerados outros objetivos, além da devida remuneração garantida em lei; as tarifas passaram a ser utilizadas como instrumento de combate à inflação, levando as concessionárias a uma drástica queda nos niveis de suas remunerações, com reflexos prejudiciais em sua capitalizaçãoe endividamento. Entretanto, para continuar a garantia de remuneração mínima de $10 \%$, foi criada uma conta para registrar as diferenças entre as remunerações reais e a mínima legal (10\%), como crédito dos concessionários junto ao governo federal, denominada Conta de Resultados a Compensar (CRC).

A partir de 1981 foi introduzida na política tarifária a figura da remuneração média do setor, como reflexo da própria insustentabilidade do nivel tarifário necessário à remuneração legal mínima de $10 \%$ em todas as concessionárias. Com essa figura, determinava-se que as transferências de recursos entre concessionários deveriam ser feitas com referência à taxa média de remuneração do setor, e não somente os excedentes a $12 \%$ a.a. (limite máximo).

Essa condição acentuou a impressão de ineficiência do setor, que a política de equalização tarifária com transferências de recursos já havia condicionado. As necessidades que eram apontadas para as transferências através da RGG, alcançavam não somente as condições naturais dos sistemas mais custosos mas também, custos elevados decorrentes de ineficiência administrativa.

A década de oitenta e o início da década de noventa foram marcadas por uma deterioração crescente do equilibrio econômico-financeiro das concessões, basicamente decorrente da insuficiência tarifária.

Chegou-se a limites criticos nos últimos dois anos, com elevados niveis de endividamento, graves dificuldades para equacionar orçamentos de investimentos e até mesmo de custeio das empresas, resultando em inadimplências não só com os credores, em sua maior parte de capital externo, mas também entre concessionários supridos e supridores.

Recentemente, determinou-se, com mais uma medida centralizadora através do Decreto $\mathrm{n}^{\circ} .409$, de 30.12.91, que a administração de parte das receitas de venda de energia elétrica seja feita pela ELETROBRÁS, com o objetivo de: a) garantir fluxos financeiros para as concessionárias federais, responsáveis pela geração da maior parte da energia distribuída, mas que não faturam diretamente aos consumidores finais, e, para a Itaipu Binacional; e b) uma tentativa de conter a elevação do nível de inadimplências, dos concessionários supridos para com os seus respectivos supridores.

Através do mesmo Decreto que centraliza parte da administração financeira em seu Artigo $6^{\circ}$. foi disposta também a desequalização tarifária, embora de forma ainda pouco clara sobre 
como se dará o retorno do setor a uma nova época de preços diferenciados. Talvez seja por regiões geocconômicas ou mesmo por área de concessão.

O baixo nível tarifário que se tem verificado particularmente em setores energéticos de Paises em desenvolvimento, por vezes tem tido como argumento o controle da inflação e capacidade da sociedade em pagar pela energia elétrica, entretanto essa politica resulta em problemas de fluxo de caixa com consequentes atrasos nas construções de obras.

Esses atrasos resultam em acréscimos de custos por juros durante a construção (JDC).

A receita de venda da energia é diretamente afetada pela insuficiência do nível tarifário, e, conforme visto no Capitulo I deste trabalho, é composta por uma parcela destinada à reinversão para a expansão do sistema. A insuficiência do nível tarifário atinge primeiramente a disponibilidade para investir, reduzindo-a e às vezes anulando-a, e por último as parcelas de recursos destinadas às despesas operacionais, comprometendo a própria confiabilidade do sistema existente.

No caso dos sistemas elétricos cujo parque gerador é principalmente hidrelétrico, as usinas representam cerca de $60 \%$ ou mais dos recursos de capital aplicados, além de serem projetos de mais longa maturação. Por serem também os projetos mais complexos e susceptiveis de atrasos, toma-los-emos na análise a seguir apresentada, procurando evidenciar as causas e os efeitos da prática de níveis tarifários artificialmente baixos e dos atrasos nos cronogramas das obras de expansão do sistema.

\section{2 - A PRESSÃO DA DEMANDA NA EXPANSÃO DO SISTEMA}

O planejamento da expansão do sistema considera as previsões de mercado como elementos catalizadores do processo de expansão, e apresenta recomendações sobre quais e em que momento devem ser construidas, as usinas planejadas.

Sendo as usinas de geração de eletricidade, obras de maturação que varia entre três e oito anos em média ${ }^{(14)}$, dentro de uma evolução normal da construção, é evidente a importância da qualidade da previsão de mercado para a decisão de se iniciar essas obras. Reconhece-se também que en Paises em Desenvolvimento, onde a atividade econômica pode variar amplamente, com elevações e reduções em curtos períodos de tempo, essa importância é ainda maior cmbora as previsões contenham inevitáveis incertezas.

No Brasil, as previsões do mercado de energia elétrica não são efetuadas de forma agregada, mas sim resultantes da consolidação das previsões das empresas concessionárias. Essa 
segregação inicial decorre, sobretudo, das diferentes realidades de cada área de concessão, cujos mercados apresentam características peculiares e dinâmicas. Posteriormente, quando de sua utilização no planejamento da expansão do sistema, são realizadas agregações de conformidade com a abrangência das malhas do sistema elétrico interligado, as quais se configuram atualmente com uma na Região Sul, outra na Região Sudeste/Centro Oeste, outra na Região Nordeste e mais uma na Região Norte.

Os métodos e critérios de previsão do mercado basciam-se na consideração dos reflexos da evolução provável de um conjunto de variáveis sócio-econômicas, além de informações sobre incrementos de carga expressivos e ligações de novos consumidores de porte. Leva-se ainda em consideração a tendência histórica do mercado.

São consideradas também as possibilidades de substituições entre energéticos e do uso racional de eletricidade, caso se apliquem mecanismos que promovam a conservação de energia.

As previsões dos requisitos de energia elétrica nas regiões citadas, bem como a consolidação para o País, utilizadas no ciclo do planejamento da expansão de 1991, com o horizonte 1992-2001, indicam um crescimento médio esperado de 5,5\% a.a., conforme mostra a Tabela 6.

Dada essa previsão, pergunta-se: que grau de certeza se tem para as decisões que serão tomadas? Tal previsão é suficientemente segura para ser utilizada como determinante da oportunidade de se decidir pelo investimento de cerca de US\$ 21 bilhões?

Se olharmos para o passado, possivelmente tentaremos aumentar ao máximo possível a certeza e a probabilidade dos cenários considerados nas projeções de demandas, pois, a experiência mostra que as projeções que sustentaram decisões de programas de obras nos últimos dez anos foram superestimadas em relação à real necessidade.

A Tabela 7 mostra as projeções da demanda para o ano de 1990, realizadas desde o ano de 1984, quando sugeriam a necessidade de se iniciar a construção de mais dez novas centrais, sendo sete hidrelétricas acrescentando 5664 MW e três termelétricas a carvão acrescentando $700 \mathrm{MW}$ à capacidade instalada do parque gerador, perfazendo um total de $6364 \mathrm{MW}$ de acréscimo total, sem considerar que também naquela época era prevista a entrada em operação em junho de 1992, da usina Nuclear Angra II, acrescentando 1254 MW ao sistema; cujos motivos provavelmente transcendiam a simples necessidade de expandir a oferta.

Aquela projeção de mercado feita em 1984, considerava os anos de 1990 a 1992 como alvo para a entrada em operação de novas usinas, ajustando a oferta ao mercado, com o critério de garantia de $95 \%$ anteriormente comentado. 
Considerando que uma usina do porte das que têm sido construidas no sistema brasileiro, demoraria em média 5 a 8 anos para ficar pronta, dentro de um desenvolvimento normal da obra, tinha-se então naquela época, que se iniciar os investimentos nas dez usinas indicadas, sem considerar a usina nuclear.

Observa-se na Tabela 7, que nos anos subsequentes as projeções para o ano de 1990 foram se aproximando do real, como era de se esperar, pois a certeza dos cenários foi aumentando, revelando um ponto crucial do processo decisório do sistema elétrico brasileiro: o tempo necessário à realização das obras de geração (principalmente as hidrelétricas) condiciona a necessidade de se tomar decisões de investimento com antecedência grande, relativamente à dinâmica dos cenários econômico-sociais.

Dai a tendência em aumentar ao máximo a qualidade das projeções, diminuindo sua incerteza.

Mas para se aumentar a qualidade dessa informação, há que se ter em conta o seu custo, conforme observa Araújo(15), pois, informação custa caro; uma busca exaustiva de informação sobre o consumo de energia pode sair mais cara que os possiveis ganhos oriundos dessa informação.

Assim, mesmo admitindo que maior qualidade nas previsões reduza erros e portanto induza a ganhos na tomada de decisão, existe uma faixa de compromisso entre custo da informação e seus beneficios, na qual se deveria trabalhar.

Segundo Araújo, não é vèrdade que mais informação resulte sempre em redução de erros. Toda informação é acompanhada de incerteza - quer sobre as quantidades mensuradas, quer sobre seu comportamento atual e sua evolução futura. Quanto maior o nivel de detalhamento, maior a complexidade e por conseguinte a incerteza resultante das incertezas individuais, e mais ainda, de sua interação; isto faz com que o volume de informação máximo, na faixa de compromisso aceitável entre custos e beneficios da informação, seja inferior ao que seria na ausência de incerteza, e o custo total maior ${ }^{\text {(xvi) }}$. A Figura 6 indica conceitual e qualitativamente o problema: 


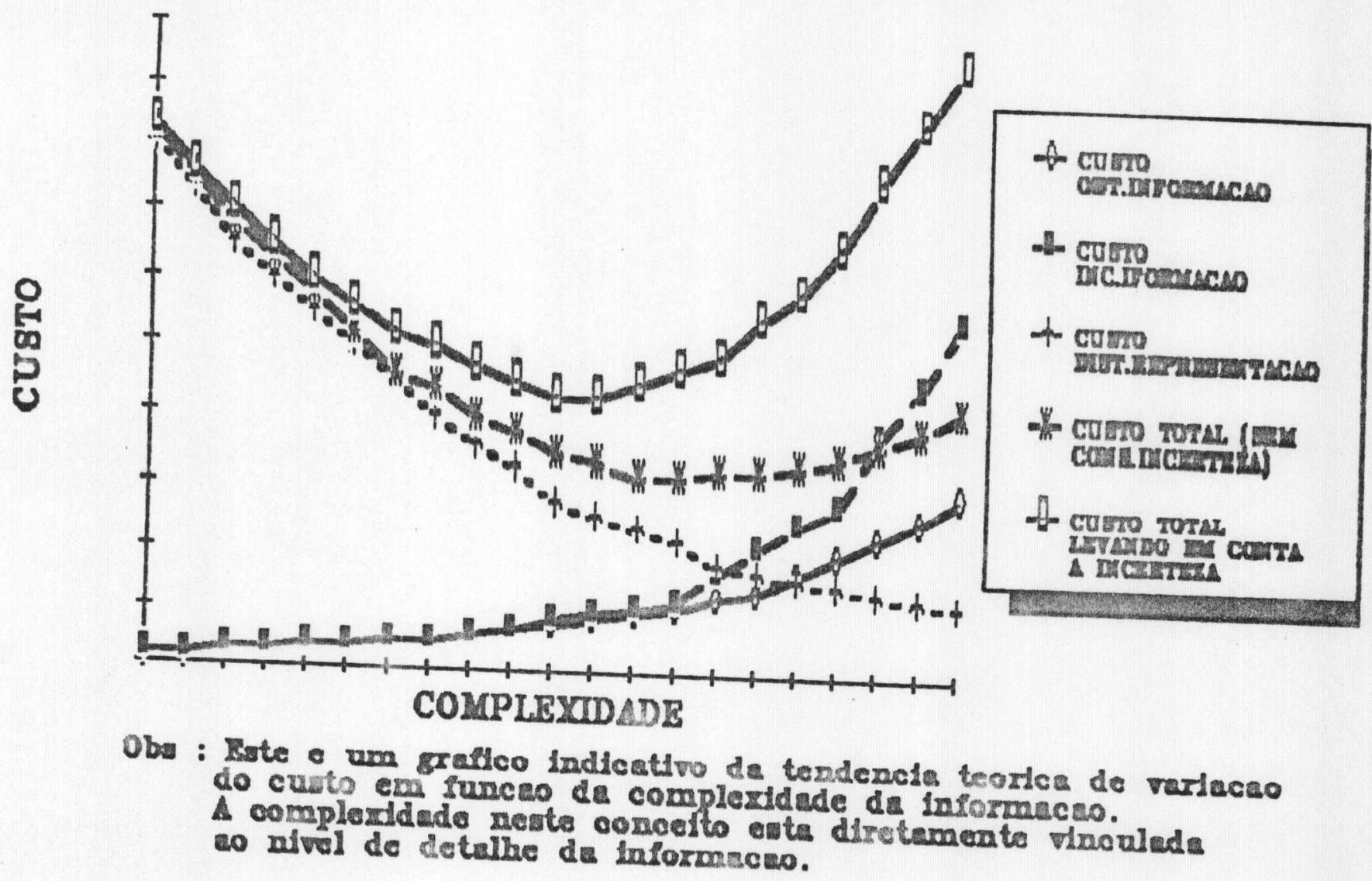

Fig. 6 - Custo versus Incerteza na obtenção de informações.

As tarifas, nesta fase do processo decisório da gestão do sistema, constituem-se em elemento componente do cenário projetado, que também deve ter atenção especial, embora tem sido considerado que o consumo não é muito elástico em relação aos preços ${ }^{(16)}$.

Para ilustrar a influência que os preços têm sobre a demanda e o potencial que isto significa em termos de orientação do mercado, citamos uma avaliação do mercado industrial de eletricidade em São Paulo, realizada sob orientação de Araújo, utilizando um modelo que relaciona o consumo de eletricidade com o PIB setorial, a variação deste ao longo dos anos, o preço da energia elétrica e o consumo do ano anterior.

Sua representação algébrica é:

$$
E_{1}=a \cdot Y_{1}^{\alpha} \cdot\left(Y_{1}, N_{1-1}\right)^{\gamma} \cdot P_{1}^{-\theta} \cdot E_{1-1}^{-\beta}
$$

onde:

$E_{1}=$ consumo do ano $t$

$E_{t-1}=$ consumo do ano anterior $(t-1)$

$Y_{1}=P I B$ no ano $t$

$Y_{t-1}=P I B$ no ano anterior ( $\left.t-1\right)$

$P_{t}=$ preço da energia no ano $t$

$\alpha=$ elasticidade consumo - PIB

$-g$ = elasticidade consumo - preço da energia

$\gamma=$ elasticidade consumo - taxa de variação do PIB

$-\beta=$ coeficiente de inércia do consumo

$\mathrm{a}=$ constante. 
Os coeficientes $\alpha, \gamma$ e g, denominados elasticidades do consumo em relação a, respectivamente, PIB, preço da energia, e, taxa de variação do PIB, têm seu conceito formulado como "o grau de sensibilidade de uma variável em relação às mudanças de uma outra".

Esse modelo foi ajustado à série histórica de consumo de energia elétrica e PIB do setor industrial de São Paulo, abrangendo os anos de 1974 a 1989.

A primeira evidência da influência dos preços observada na avaliação foi quanto ao superávit de energia ocorrido no período 1982-1985, provavelmente decorrente de um descompasso entre a expansão do sistema e a realidade do consumo, quando foi oferecida a modalidade de energia EGTD-Energia Garantida por Tempo Determinado, a preços bastante inferiores aos já baixos preços praticados naquela época, podemos observar isto na Tabela 8.

O modelo não se ajustou à série que contava com dados desde 1974, pois, a EGTD resultou num intercepto à continuidade da mesma.

Ao se eliminar da série dados relativos àquela modalidade especial de consumo, o modelo apresentou razoável ajuste, resultando numa elasticidade consumo-preço da energia de $-0,06389$, conforme mostram os resultados da regressão apresentados na Tabela 9.

Concluiu-se, naquela avaliação, que num periodo de recessão gasta-se mais energia relativamente a um periodo de crescimento da economia, conforme observado nas variações da intensidade de energia elétrica no PIB; a ocorrência deste fato coincide com os baixos níveis tarifários verificados no Brasil nas épocas de recessão, prática que foi justificada pela necessidade de contenção da inflação.

Concluiu-se também, a partir da aplicação do modelo ajustado para projeções do consumo no quadriênio 1991-1994, com a simulação de uma recuperação tarifária que eleva o nível médio das tarifas até U\$58,63/MWh em 1994, que a influência de impactos tarifários no consumo de energia elétrica justifica a análise dos preços nos cenários projetados, e que esse tipo de análise oferece melhores resultados quando feita para classes especificas do mercado.

Não é objeto deste trabalho aprofundar nessa questão, mas, devemos registrar a necessidade de razoável coerência entre os estudos de mercado e as decisões recomendadas no planejamento da expansão.

Particularmente em paises como o Brasil, as previsões de mercado devem conter especial ênfase na identificação e análise da demanda, de forma a se ter o necessário conhecimento do comportamento da demanda proveniente de usos ineficientes. Esse conhecimento é básico para um

- programa de orientação para a eficiência energética, em especial quando as tarifas são utilizadas como sinalizadores. 


\section{3 - O PROCESSO DECISÓRIO DA EXPANSÃO}

O processo decisório da expansão requer seja desenvolvido com prazos e critérios determinados, com revisões sistemáticas que permitam ajustes das decisões tomadas, porém, sem comprometer as obras já iniciadas, pois, sem esse cuidado o processo seria incoerente com uma de suas premissas básicas - a minimização dos custos da expansão.

No sistema elétrico brasileiro, esse processo é desenvolvido pelo Grupo Coordenador para o Planejamento do Sistema - GCPS, em ciclos anuais, com base em critérios especificos para a simulação das condições do sistema para o atendimento do mercado.

O critério para se determinar a expansão necessária do parque gerador considera que este deve atender à carga solicitada com uma garantia de atendimento tal, que o risco de qualquer racionamento não deve exceder o patamar de $5 \%$ em cada ano do horizonte de planejamento ${ }^{(17)}$.

A medida do desempenho do parque gerador é feita através da simulação de sua operação com cerca de 2000 possibilidades distintas de afluências hidráulicas ao sistema, sendo o risco anual de déficit medido pela frequência relativa de séries em que se verifica algum déficit, independentemente de sua magnitude.

0 parque gerador é atualmente interligado, permitindo transferências de grandes blocos de energia entre as regiões Sudeste e Sul, condicionando a decisão de expansão do sistema a um planejamento integrado.

Assim, a demanda projetada desencadeia um processo de decisões que culminam com a construção de novas usinas, sendo que devido ao porte do sistema e do mercado, pequenas variaç̃es nas projeções de demanda são suficientes para alterar razoavelmente o programa de obras.

Os resultados preliminares do ciclo de planejamento da expansão realizado em 1991, com o horizonte de 1992-2001, embasam a recomendação de se construir mais dezesseis usinas na Região Sul e trinta na Região Sudeste, considerando apenas aquelas que deverão entrar em operação no período 1997-2001.

As Tabelas $10 \mathrm{e} 11$ apresentam as condições de atendimento do sistema e o programa de obras recomendado. O custo marginal resultante é de U\$ 46,58/MWh.

Para a realização desse programa de obras, serãonecessários investimentos da ordem de US\$21.2 bilhões no período 1992-2001, com uma média de US\$2.1 bilhões/ano.

A captação desses recursos na condição atual do Pais, representa enormes dificuldades para as empresas de geração de eletricidade, pois, não há poupança interna que possa ser alocada a 
investimentos desse porte, e a poupança externa além de estar se tornando crescentemente seletiva em termos da natureza dos projetos para sua aplicação, encontra nos projetos do Brasil muitas reticências, pela possibilidade de novas interrupções nos pagamentos da dívida externa.

Observa-se que as decisões dos concessionários, ao iniciarem novas obras de geração, baseiam-se em análises de investimento tanto sob o enfoque microeconômico como o social, as quais também se constituem em elementos requeridos pelos agentes financeiros em suas decisões sobre empréstimos.

Os resultados dessas análises têm frequentemente se apresentado favoráveis, no enfoque social, devido ao atendimento do mercado para o que são propostas as obras e também pela caracteristica de multiplicadores de beneficios sociais que têm os projetos de geração de energia elétrica.

Entretanto, no enfoque microeconômico, as análises têm revelado a desfavorabilidade dos empreendimentos, devido à baixa expectativa de remuneração, decorrente do baixo nível tarifário.

As decisões têm sido tomadas, principalmente em função dos resultados da análise social, com argumentos de que a recuperação do nivel tarifário torna-se imperiosa e é uma preocupação do governo federal.

Ocorre que tais argumentos foram aceitos inicialmente pelos credores, mesmo porque o governo federal avalizava os empréstimos dos concessionários; mas, com a experiência de alguns projetos, que hoje se mostram com fluxos financciros negativos, com as tarifas não tendo sido recuperadas e até mesmo decrescido em niveis reais, e, principalmente devido à inadimplência dos concessionários e do País junto aos credores externos, há uma severa restrição dos agentes financeiros para novos empréstimos e financiamentos para empreendimentos no Setor Elétrico Nacional ${ }^{(18)}$.

Nessa situação, as recessões econômicas resultam em alterações substanciais no desempenho dos projetos, ocasionando atrasos nas obras e aumento de custos por juros durante a construção, por outro lado o mercado se realiza em niveis substancialmente inferiores às projeções originais.

O requisito de energia na Região Sudeste e Centro Oeste (exclusive aquele relativo à área de concessão da ENERSUL) para 1992, previsto em 1985 no ciclo de planejamento do GCPS para o período 1986-1995, foi de 20947 MWano, a Tabela 12 apresenta a composição dessa previsão de mercado pelas regiões do sistema interligado.

Para atender a esse mercado, foi recomendada a entrada em operação das Usinas: Segredo e D. Francisca, na Região Sul, acrescentando 1384 MW à capacidade instalada, e as UHE's Sta. Branca, Manso, Nova Ponte, Porto Primavera, e a Usina Nuclear Angra II, sendo que a UHE Porto Primavera deveria já ter quatro de suas dezoito máquinas operando em 1992, na Região 
Sudeste/Centro Oeste, acrescentando 2425 MW à capacidade instalada, além de outras que já se encontravam em construção.

As condições de atendimento simuladas naquela época apontavam para riscos de déficit de 10,1\% no Sul e 12,8\% do Sudeste em 1992, conforme mostra a Tabela 12.

No periodo que se passou, desde 1985 até 1991, o Pais passou por períodos de altas da inflação e fortes recessões conforme mostra a Tabela 13.

Hoje, em 1992, o atendimento do sistema está sendo feito com uma sobra de cerca de $2200 \mathrm{MW}$, as previsões de mercado apontam para que aquele nível de mercado total previsto somente deverá ocorrer em 1996, caso a evolução do mesmo nos próximos anos repita a performance verificada nos últimos cinco anos! Há que se considerar, entretanto, que uma retomada vigorosa da atividade econômica pode levar a curto prazo dessa situação de sobra ao déficit.

O cronograma de obras atual, comparado àquele de 1985, considera umescorregamento de 5209 MW por cerca de 20 meses, como se pode ver na Tabela 14

É oportuno ressaltar neste ponto, o alto custo decorrente da tomada de decisões na expansão do sistema, considerando que parte significativa da demanda projetada poderia ser reduzida com uma orientação para o uso eficiente, gerando necessidades menores e consequentemente menores programas de obras sendo decididos.

Esses atrasos nas construções se refletem em importantes acréscimos nos custos finais das obras, resultando em energia cara, com custos provavelmente bastante superiores aos que a sociedade está disposta a pagar, se lhe fosse dada a oportunidade de participar do processo decisório do setor de forma mais direta.

Embora as recessões econômicas sejam fatores preponderantes nas causas dos atrasos de obras, há outros fatores que também contribuem para esse resultado, conforme a seguir descrito.

\section{4 - ACRÉSCIMOS DE CUSTOS POR ATRASOS NAS CONSTRUÇÕES}

As previsões de custos e cronogramas de obras são projeções de evoluções, condições e combinações futuras de variados elementos, os quais dependem do desempenho de organizações humanas, que por sua vez estão sujeitas a uma incerteza natural c dependem do ambiente institucional, econômico e social em que se inserem. 
Observa-se, frequentemente, que as projeções de custos e cronogramas contêm uma certa dose tendenciosa por sua favorabilidade, além das incertezas naturais inerentes às projeções. As tendências à subestimação de custos e prazos às vezes se acentuam quando o processo decisório da construção da obra torna-se vulnerável a pressões de interesses econômicos e políticos; isto depende bastante do modelo institucional com o qual transcorre aquele processo.

Os principais fatores que representam causas potenciais de problemas com custos e cronogramas são os seguintes:

(a) Qualidade insuficiente das projeções de custos e evolução das obras;

(b) Falha na implementação do projeto;

(c) Alterações no projeto;

(d) Condições do ambiente externo, alteradas em relação à previsão original.

Provavelmente os dois últimos fatores, mas principalmente o último, são os mais frequentes. No caso dos projetos brasileiros, pode-se admitir a expectativa acima, considerando a experiência acumulada pelo Setor Elétrico Nacional na implementação de usinas; entretanto, admite-se também que foram tomadas decisões de expansão do sistema com base em projeções tendenciosas, e, por motivos que não exclusivamente $o$ atendimento ao mercado.

Mas, o fator mais acentuado é a constante e ampla variação das condições econômicas e sociais, tais como taxa de inflação, nível de atividade econômica competindo para os mesmos recursos, e a disponibilidade de capital. A incerteza da evolução dessas condições é tão grande que os técnicos responsáveis pela elaboração do planejamento da expansão têm tendido a recomendar projetos de maturação mais curta.

O Departamento de Indústria e Energia do Banco Mundial analisou a questão dos custos e cronogramas de obras em 56 projetos de Paises em desenvolvimento da África, Ásia, Oriente Médio e América Latina, incluindo dez projetos brasileiros, concluindo que $90 \%$ dos projetos apresentaram acréscimo de custo conforme mostra a Tabela 15.

Cerca de um quarto daqueles projetos teve aumento de custos de no mínimo $40 \% \mathrm{em}$ relação à projeção inicial, como mostra a distribuição da Tabela 16.

A análise realizada apresenta como conclusão que três fatores concorreram decisivamente para os desvios observados:

(a) Manipulação de Padrões e Princípios Técnicos de Projeções de Custos

Tendo sido identificados casos em que determinados custos não foram contemplados na projeção inicial e somente mais tarde vieram a ser identificados. 


\section{(b) Problemas Geológicos}

Normalmente eventuais problemas geológicos resultam em grandes acréscimos de custos. Embora as sondagens e estudos geológicos tentem prever todas as condições possíveis de se encontrar, há uma incerteza residual.

\section{(c) Falhas na Implementação dos Projetos}

São em geral devidas à incompetência administrativa ao nível dos projetos. Essas falhas são frequentemente associadas à debilidade institucional por parte do agente financiador, e, ao desempenho insuficiente por parte da empresa de energia e dos consultores que eventualmente participam do projeto.

O referido trabalho também conclui que se estes três fatores forem controlados, grande parte dos acréscimos pode ser eliminada, reduzindo significativamente os problemas que decorrem dos atrasos nos cronogramas, mantendo-os num grau administrável.

Essa situação tem motivado tentativas variadas para soluções dos problemas que foram aqui apresentados.

No Brasil tem-se registrado esforços no sentido de uma profunda reformulação institucional, tem-se tentado também uma maior aproximação com a iniciativa privada, objetivando aliviar a responsabilidade dos governos em novos investimentos no sistema, tentativas essas que parecem se complementar. Tem-se a impressão de que em realidade ambas são necessárias e urgentes para a retomada do desenvolvimento equilibrado do setor elétrico nacional.

Porém, existem também outras medidas que exigem menores esforços e alterações institucionais, e que têm como mérito a promoção de uma maior racionalidade e eficiência na utilização e expansão do sistema, tais que exploram o potencial da reação do mercado diante de orientações especificas.

O resultado prático mais imediato dessas medidas é a possibilidade de se refrear a necessidade de expansão do sistema sem reprimir a demanda imprescindivel ao desenvolvimento econômico e social; trata-se de se promover a utililização racional e eficiente de energia, resultando na condição de se atender a um maior número de consumidores e a um maior consumo de energia sem expandir o sistema.

Uma dessas medidas é o objeto das discussões finais da presente dissertação, a orientação para a eficiênciá através das tarifas. 


\section{CAPITULO III}

\section{TARIFAS ORIENTADAS PARA A EFICIÊNCIA ECONÔMICA E ENERGÉTICA}

\section{1 - CONSIDERAÇÕES SOBRE A ORIENTAÇÃO DE TARIFAS}

\section{1 - ESCOPO E OBJETIVOS DA TARIFAÇÃO}

Dentro do contexto da eficiência energética, podemos considerar a tarifação como um, dentre outros, dos instrumentos para a otimização da expansão e operação do sistema energético.

Alguns instrumentos se caracterizam por controles fisicos da carga, limitando-a a determinados niveis. Tais instrumentos se adequam a uma administraçãode curto prazo, particularmente quando há escassez imprevista da oferta, ou scja, quando o sistema em opcração foi projetado para atender a uma carga significativamente menor.

Alguns outros métodos se constituem em modelos de simulação do sistema, os quais apontam para soluções de menor custo para a produção de uma determinada forma de energia, incluindo análises sobre o melhor mix de fontes de produção.

A tarifação se constitui em um instrumento adequado à otimização de longo prazo, porquanto a mesma está diretamente relacionada com as decisões de investimento, as quais são tomadas com relativa antecedência em relação à realização da oferta .

O sistema elétrico é intensivo em aplicação de capital e as decisões de investimento têm sido tomadas com base no método convencional do menor custo para o atendimento da demanda por energia elétrica. Com a devida consideração das possibilidades de substituição entre energéticos, o que deve estar refletido na sinalização tarifária, condiciona-se a tarifação à otimização de longo prazo; sob o ponto de vista da demanda, observa-se o fato de que os equipamentos elétricos são caros em relação à renda do consumidor, principalmente $\mathrm{em}$ países em desenvolvimento, além de terem longa vida útil, o que limita a disposição dos consumidores em responder à sinalização tarifária a curto prazo, condicionando assim, por mais uma razão, a tarifação a objetivos de longo prazo.

Os objetivas da tarifação estão assim diretamente relacionados aos do planejamento, mas, são mais específicos.

Primeiro, a alocação de recursos que pode ser feita via tarifas, tanto intra setor elétrico como entre este e o resto da economia, exerce função norteadora para o processo de 
planejamento, além de atender a politica sócio-econômica; para este último, tem-se o uso dos preços sombra como instrumento para ajustes econômicos do $2^{\circ}$. Ótimo.

Segundo, na eventual necessidade de subsidiar classes pobres, garantido-lhes acesso a quantidades mínimas de energia, as tarifas podem ser usadas em subsidios cruzados.

Terceiro, como mecanismo calibrador da arrecadação de recursos de capital na exata necessidade para o finaciamento da expansão do sistema.

Quarto, a conservação de energia, como é o objeto do presente trabalho, tem nas tarifas um meio para clara sinalização e orientação dos consumidores, inclusive podendo incorporar sinalizações especificas para algumas classes cujos equipamentos ou instalações não têm eficiência desejável.

Quinto, embora as reações que se planejem desencadear com determinada orientação aos consumidores possam ser complexas, as mesmas podem ser simplificadas através da sinalização tarifária. Reconhece-se mesmo que as estruturas tarifárias devem ser o mais simples possível, e, com estabilidade suficiente para se garantir credibilidade ao sinal apresentado

Finalmente, existem outros objetivos específicos que podem ser alcançados com o auxílio de tarifas orientadas tais como promover determinado desenvolvimento regional, determinado tipo de exportação, além de outros sócio-políticos e ambientais.

\section{2 - ORIENTAÇÃO DAS TARIFAS}

A orientação das tarifas dos diversos energéticos de forma coerente com a politica energética é fundamental para os objetivos da mesma. Particularmente, o objetivo de conservação pode ser mais facilmente alcançado, com tarifas orientadas para a eficiência econômica e no uso dos diversos energéticos.

A fixação de tarifas abaixo do real custo econômico, se por um período de tempo muito grande (mais de um ano), acaba por incentivar a escolha desotimizada de tecnologia para as plantas e para o consumo, na medida em que as tecnologias mais antigas e menos eficientes são mais baratas.

A sensibilidade de determinados nichos do mercado consumidor e de potenciais geradores independentes de energia, diante dos preços de energia, tem sido subestimada nos paises em desenvolvimento, onde o papel do governo alcança maior abrangência do que noutros paises onde o mercado e o estado de concorrência são mais adiantados. As politicas de preços nesses países têm 
tendido a ignorar ou tềm falhado em considerar a existência de algum grau de liberdade na escolha dos consumidores quanto aos produtos que podem ser colocados à sua disposição, bem como na escolha dos investidores quanto aos empreendimentos nos quais se pode investir, dado um determinado nivel de preços. Acredita-se que, no caso do setor elétrico brasileiro, uma orientação de preços que objetive incentivar investimentos de geradores independentes possa contribuir de forma importante para a solução da capacidade de expansão da oferta.

As tarifas podem sinalizar diversas orientações da politica energética; propõe-se aqui a segregação desses sinais em dois grupos distintos: a sinalização econômica, intrínseca de cada sistema de produção distribuição de energia especificamente; e, a sinalização para odesenvolvimento do modelo energético proposto para a região onde o consumo se realiza.

A sinalização econômica está associada à orientação racional do consumo de determinado energético com eficiência econômica, baseando-se no real custo econômico incorrido ao se atender a demanda por energia. Tal sinalização econômica pode ser conseguida com a aplicação de uma estrutura de preços com base em custos marginais, conforme anteriormente comentado.

A sinalização para o modelo energético que se objetiva alcançar está associada à eficiência nos usos, à substituição entre energéticos e à dinâmica da matriz energética.

Tal sinalização,coerente com a politica energética, pode ser conseguida com a aplicação de taxas ou subsídios temporários, sobre o consumo de determinados energéticos, em determinadas classes de consumidores, regiões geográficas, ou, sobre a comercialização de equipamentos que consumirão energia com menor ou maior eficiência.

Ass consequências da orientação das tarifas são, por conseguinte, de especial interesse na discussão do uso eficiente de energia.

O planejamento de sistemas de energia envolve ambos os lados do problema, a demanda e a oferta; nenhum dos lados pode ser ignorado.

Da mesma forma, as tarifas como instrumentos da politica energética não podem ser fixadas sem considerar a demanda e a oferta. Entretanto, há que se considerar que na discussão das tarifas ter-se-á que prestar maior atenção aos usos, ou, ao lado da demanda.

As relações entre a oferta e a demanda são estudadas há muito tempo, conforme relatado anteriormente, no Capitulo I da presente dissertação. O fato dessas relações serem dinâmicas no tempo, condiciona à orientação das tarifas um caráter também dinâmico,embora suas mutações não podem ser realizadas de forma abrangente em curtos periodos de tempo, sob pena de causar desorientação aos consumidores. 
A estabilidade das tarifas, ou seja, os espaços de tempo entre uma alteração e outra, deve ser adequada aos prazos de maturação de investimentos e tecnologias, bem como à renda e à evolução que se propõe para a matriz energética.

Os principais fatores que afetam a demanda por energia são: a relatividade de preços entre setores da economia; a presença de energéticos concorrentes; a renda do consumidor; o estágio tecnológico da produção e do consumo; e, as expectativas sócio-econômicas.

As tarifas refletem com muita propriedade para o consumidor o valor de cada energético individualmente e em relação aos outros energéticos disponíveis.

Observa-se o exemplo dos preços do petróleo nos anos anteriores a 1973, que refletiram a abundância, qualidade e versatilidade, que colocaram o valor relativo do mesmo acima dos valores do carvão e do gás natural.

O carvão - um combustível fóssil que foi largamente utilizado antes da descoberta do petróleo - perdeu sua participação no mercado de energia por ser poluente e incômodo para se usar, comparativamente ao petróleo.

Então, o preço do petróleo relativamente baixo foi responsável pelo desenvolvimento de uma tecnologia petroquímica dinâmica, pela crescente dependência das economias por petrólco, e, pelo desenvolvimento de uma estrutura de mercado pouco elástica.

Como os preços do petróleo cresceram com as duas crises, 1973 e 1979 , tem-se promovido aumentos na eficiência de seu uso, através de novas tecnologias. Os consumidores têm ajustado seus modelos de consumo, considerando sua renda e restrições orçamentárias.

Assim, o carvão voltou a ser interessante em alguns casos, como energético alternativo aos derivados de petróleo. Também passaram a ter alguma perspectiva de utilização os Resíduos Ultraviscosos de Petróleo, chamados residuos de fundo de barril, bem como outras novas fontes de energia.

É possivel constatar que em certas circunstâncias os altos preços do petróleo resultaram em redução do consumo sem afetar o crescimento econômico. Como no caso de alguns paises da OCDE, onde se reduziram as distâncias na realização dos transportes de carga com arranjos mais eficientes das atividades econômicas.

Observa-se também que os preços dos energéticos têm influência potencial sobre o setor produtivo, na medida em que participam nos custos de produção de bens e serviços.

Especificamente no setor produtivo de energia, que nos países em desenvolvimento têm carecido da participação do capital privado para a continuidade da expansão dos sistemas energéticos, a sinalização tarifária pode desempenhar importante papel. A participação da iniciativa 
privada em investimentos do setor elétrico, como exemplo, pode ser francamente estimulada com tarifas orientadas em coerência com políticas energéticas regionais, incentivando também a cogeração onde a mesma for econômica e conveniente, estabelecendo interessantes sinergismos entre o sistema tradicional e geradores independentes.

Um importante fator também considerado na orientação das tarifas para a eficiência energética, é a elasticidade, parâmetro fundamental para balizar a aplicação das tarifas.

As elasticidades-preço dos consumos dos diversos energéticos nas diversas classes de consumidores, bem como as elasticidades-renda dos mesmos, constituem-se em mapa orientativo para as intensidades dos efeitos da política energética.

Utilizando tal mapa na indução da conservação, pode-se identificar onde e quão significativos serão os efeitos de alterações de preços sobre o consumo. Também tornam-se mais evidentes as movinnentações das funções da oferta e da demanda relacionadas com a substituição de energéticos entre si.

Finalmente, propõe-se fixar o conceito da orientação de tarifas para a eficiência econômica e energética no uso dos diversos energéticos, como se referindo à sinalização ao consumidor e ao produtor de energia, quanto à alocação de um determinado energético segundo seu mais alto valor de uso, ao menor custo possivel para a sociedade.

Tal conceito não significa somente reduzir unidades fisicas por unidade de capital produzida e consumida, mas também significa minimizar o custo de produção de cada unidade fisica por unidade de capital produzido, com o objetivo paralelo de aumentar a produção econômica aplicando recursos em cmpreendimentos de retorno mais rápido. Há uma certa classificação dos investimentos que se pode fazer, dentre os empreendimentos necessários em uma nação, alguns deles têm retorno mais lento e difuso e são em geral empreendimentos em infraestrutura, como é o caso dos sistemas energéticos; outros, têm retorno mais rápido e se caracterizam empreendimentos que dependam dos primeiros.

É necessário observar,neste ponto, que a proposta acima foi imaginada a partir de alguns exemplos de formas de tarifas praticadas por empresas de eletricidade norte-americanas ${ }^{(x)}$, os quais sugeriram grande ệnfase na sinalização de preços, como forma de orientação para os consumidores. 


\section{3 - ORIENTAÇÃO PARA A EFICIÊNCIA ECONÔMICA E ENERGÉTICA}

Os assuntos discutidos até o presente momento desta dissertação foram a base para algumas conclusões importantes a respeito das tarifas de energia elétrica: sua teoria e metodologias de cálculo, o desempenho observado na prática e o conceito de orientação para a eficiência econômica e energética.

Torna-se então necessário fixar claramente as caracteristicas próprias a essa orientação para a eficiência.

Assim, no presente item são adicionadas algumas colocações nesse sentido.

\section{(a) Eficiência Econômica}

Conforme demonstrado anteriormente, a base de custos marginais se constitui em referência tal para os preços de energia, que incorpora os reflexos das decisões dos consumidores ao demandarem energia elétrica ao sistema, como também das decisões dos gestores deste ao equacionarem o atendimento à demanda.

Estão subjacentes ao resultado dos custos marginais e ao processo decisório de gestão do sistema, as tecnologias atuais do sistema e da carga, bem como as formas e hábitos em algumas classes de clientes, tradicionalmente empregados ao consumirem energia elétrica.

Essa relação de causa e efeito, presente na metodologia de apuração dos custos marginais, permite antecipar o conhecimento das tendências do custo que se está a incorrer com energia elétrica, indicando de forma clara a direção para a eficiência econômica no uso da eletricidade. Neste ponto é importante considerar o fato de que essa sinalização para a eficiência econômica será tanto mais clara e eficaz, quanto mais próximas dos respectivos custos marginais estiverem as estruturas de preços dos diversos energéticos que concorrem para a composição da matriz energética. Assim, imaginariamente todos os preços dos diversos energéticos deveriam refletir custos marginais ${ }^{(19)}$, se se quizesse uma orientação econômica pura, totalmente isenta de subsidios ou sobrepreços.

Em realidade, é praticamente impossível esse ideal imaginário, dada a complexidade do conjunto de fatores que influem na determinação dos preços de energia, mas justifica-se buscar a maior proximidade possível com a estrutura de custos marginais, pois, a preconizada sinalização para a eficiência econômica é tão mais clara quanto maior for a equivalência em questão.

Justificam-se mesmo esforços constantes pelo governo e sociedade, no sentido dessa sinalização econômica clara para a energia, e isso encontra respaldo numa consciência internacional 
hoje existente em torno dos aspectos da energia relacionados com o problema global da economia: a crise da divida internacional. Essa consciência foi detalhadamente exposta por GOLDEMBERG (1988).

Enquanto a solução da crise da divida passa pela disposição de condições básicas para o desenvolvimento da maioria dos paises do hemisfério Sul, os países do Norte têm que se preparar para uma nova era de recursos mais e mais escassos ${ }^{(x i v)}$; nesse contexto, a busca pela eficiência econômica é essencial, e para o Brasil, enquanto país em desenvolvimento e com potencial para se desenvolver celeremente, parece ser ainda mais fundamental.

Assim, a alocação de recursos de capital requer extrema atenção, particularmente no estágio de desenvolvimento econômico em que se encontra o Brasil, e considerando a expectativa de uma época de alto custo do capital internacional, ao final do século XX.

\section{(b) Eficiência Energética}

No Brasil, pode-se identificar um potencial significativo para conservação de eletricidade, representando a possibilidade de postergar o início de obras de intensiva aplicação de capital com grande economia de divisas para a nação, e ao mesmo tempo permitir a continuidade do crescimento.

As demandas por eletricidade no País têm sido projetadas com um crescimento anual da ordem de 5 a $6 \%$ nos quatro últimos processos decisórios do planejamento da expansão (veja a Tabela 17).

Atender a esse crescimento significa decidir pela construção de uma nova usina de cerca de 1500 MVA a cada ano, com investimentos da ordem de US\$ 3.9 bilhões/ano, somente considerando as Regiões Sul+Sudeste+Centro-Oeste (veja a Tabela 18).

Acrescente-se a isso, o fato de que a real sinalização que se tem apresentado, através dos preços da eletricidade, incentiva o consumo pois há na realidade um grande subsidio do Setor Elétrico Nacional para os demais setores da economia.

As tarifas que se têm praticado são cerca de $55 \%$ inferiores aos custos efetivos (veja a Tabela 19).

Essa prática, além de enfraquecer fortemente o Setor Elétrico, em termos de sua Geração Interna cie Recursos (GIR), que segundo seu modelo econômico deveria corresponder a 1/3 dos recursos necessáriós à expansão do sistema, acaba por realimentar o processo inflacionário, porquanto o capital investido no sistema elétrico provem em sua maior parte da poupança externa, impactando a divida externa e o déficit público (veja a Tabela 20).

Sem analisar o custo do beneficio dessa eletricidade para a economia como um todo, 
mas centrando a questão na possibilidade de que para proporcionar o mesmo beneficio poder-se-ia investir algo menos, se se conseguisse um uso especifico mais eficiente, pode-se aquilatar o beneficio do esforço que deve ser empreendido.

Pode-se estimar tal beneficio a partir do potencial para conservação de energia elétrica no País, cuja estimativa aponta para um percentual entre $6 \%$ e $23 \%$ de possivel redução (veja a Tabela 21).

Entende-se que a consecução dessa redução do consumo, depende por um lado da ação dos próprios consumidores, revendo suas instalações, equipamentos e hábitos, e, por outro lado depende também da indústria de equipamentos elétricos, responsável por colocar no mercado equipamentos de menor consumo específico.

O incentivo para essa ação encontra na sinalização de preços um instrumento viável, e com essa consideração, busca-se formular e avaliar os impactos de uma política de orientação das tarifas de eletricidade para promover as ações dos consumidores, resultando na conservação de energia elétrica.

\section{2 - PROPOSTA DE FIXAÇÃO DE TARIFAS DE FORMA ORIENTAB́ LARAA} A EFICIÊNCIA ENERGÉTICA
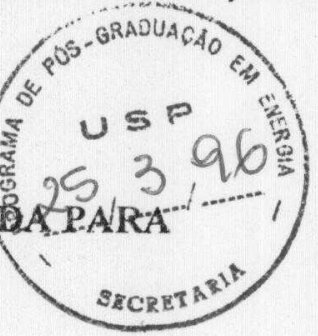

Considerando as possibilidades de redução no consumo por alteração de hábitos dos consumidores e por substituição de equipamentos por outros de menor consumo específico, formulase a proposta a seguir para a orientação de tarifas de energia elétrica de forma a incentivar as citadas reduções.

Essa orientação para a eficiência consiste na identificação de padrões estatísticos do consumo, em função dos quais é analisada a parcela do mesmo que poderia ser reduzida ou eliminada, com equipamentos mais eficientes e hábitos adequados à racionalidade preconizada.

Para tanto, devem ser consideradas as tecnologias disponiveis e acessíveis ao mercado consumidor, a capacidade de mudança de hábitos dos consumidores e a necessidade de informações que devem ser dirigidas aos diversos segmentos da sociedade em forma adequada.

Essa identificação deve considerar as diversidades entre atividades econômicas, niveis do sistema e classes de renda, de forma a segregar conjuntos homogêneos que possam receber sinalizações especificas.

A sinalização, propriamente, consistiria na aplicação à parcela do consumo então 
identificada como acima, de tarifas isentas de quaisquer subsídios ou sobre-preços e que reflitam os custos marginais de expansão da oferta. Tal parcela deveria também ser destacada na conta apresentada ao consumidor; para aqueles consumidores que conseguirem pautar seu consumo em niveis abaixo dos padrões anteriormente mencionados, seria concedido um desconto sobre o consumo verificado, na proporção do valor da energia reduzida, o que seria traduzido cm um prêmio pelo beneficio econômico que estaria sendo proporcionado, colaborando para a decisão de um programa de expansão menor.

\section{3 - VALOR ECONÔMICO DO SINAL TARIFÁRIO}

O prêmio aos consumidores que reduzirem seus consumos ou que já os tenham abaixo dos padrões de eficiência para a classe que se enquadram, tem um valor econômico.

Esse valor deve ser equivalente ao valor da energia conservada, o qual deve ser maior do que a soma do acréscimo marginal de custos com o programa de conservação empreendido e com a redução marginal dos beneficios do consumo renunciado.

$$
\varphi_{\mathrm{B}}>\varphi_{\mathrm{Cl}}+\varphi_{\mathrm{C} 2}
$$

onde:

$\varphi_{\mathrm{B}}=$ benefício marginal, ou valor da energia conservada

$\varphi_{\mathrm{Cl}}=$ acréscimo marginal de custos com o programa

$\varphi_{\mathrm{C2}}=$ redução marginal nos benefícios do consumo

A apuração desse beneficio deveria ser feita com base no periodo de tempo correspondente à vida útil econômica das plantas; entretanto, num programa de conservação que utilize tarifas orientadas, poder-se-ia adotar o periodo de tempo de duração do programa.

$$
\sum_{t=0}^{n} B_{t} /(1+r)^{t}>\sum_{t=0}^{n}\left(C_{11}+C_{2}\right) /(1+r)^{t}
$$

onde:

$B_{1}=$ energia conservada por ano

$C_{11}=$ custo adicional com o programa de conservaçăo por ano

$\mathrm{C}_{\mathrm{a}}=$ custo da perda do beneficio do consumo reduzido por ano

$t$ = número de anos do programa de conservaçăo

$r$ = taxa de atualizaçăo

Observa-sé que um programa dessa natureza devido às próprias características da sinalização tarifária bem como seus efeitos, deveria ter duração plurianual, com revisão das intensidades dos sinais a cada ano. 
Uma metodologia para a determinação do beneficio da energia conservada pode ser formulada a partir de avaliações de custos marginais de expansão do sistema, com e sem a adoção de um programa de incentivo ao aumento da eficiência do consumo.

Certamente os custos marginais de todos os segmentos do sistema podem ser considerados nessas avaliações, ou mesmo, podem ser considerados os custos marginais dos fornecimentos típicos, os quais contemplam todos os segmentos do sistema envolvidos no atendimento.

Entretanto, propomos aqui considerar num primeiro plano, apenas o segmento de produção, ou seja, o parque gerador, cujos custos marginais podem ser associados de forma mais direta à relação entre o consumo e a gestão do sistema. Essa relação pode ser evidenciada de forma mais didática, tornando-se mais simples a sinalização tarifária.

Alem dessa maior facilidade, há também o fator representatividade, pois os custos marginais de produção representam cerca de $65 \%$ a $80 \%$ dos custos de fornecimento, dependendo do ponto do sistema onde o consumidor se conecta.

O valor do prêmio seria equiparado à diferença entre os custos marginais de expansão do parque gerador, resultantes de simulações do mesmo com dois programas de obras: um que não considera a redução de consumo proposta para ser conseguida a partir da sinalização tarifária por aumento da eficiência, e outro, menor, que considera tal redução.

O programa de obras maior, de maior custo, seria o resultante do processo normal de planejamento da expansão, projetado para atender ao mercado previsto sem a consideração da sinalização tarifária em questão.

O programa de obras menor, de menor custo, seria o resultante de uma simulação de ajuste da oferta a um mercado menor na proporção das reduções propostas para o programa de incentivo à eficiência. Esse programa de obras reduzido não conteria todas as obras previstas no programa original, porquanto algumas delas não mais seriam necessárias no horizonte determinado no planejamento da expansão, podendo ser postergadas.

Os ajustes das ofertas para os dois mercados considerados,quais sejam: (a) aquele resultante da projeção normal da demanda; e (b) aquele resultante da projeção com redução por aumento de eficiência, obedecem os critérios para as decisões ótimas da expansão do sistema em cada caso.

O Apêndice A apresenta uma descrição desses critérios, bem como dos modelos computacionais empregados, e, dos cálculos práticos dos custos marginais de expansão. 


\section{4 - EXERCÍCIO DE CÁlCULO DE SINAL TARIFÁRIO PARA A PROPOSTA DE ORIENTAÇÃO DE TARIFAS}

Essa idéia foi exercitada tomando por base o ciclo de planejamento realizado em 1991, para o Sistema Interligado Sudeste-Sul do Brasil.

A seguir estão apresentados os resultados do exercício de cálculo, que basicamente consistem nas condições de atendimento e parâmetros das simulações do sistema, bem como a redução proposta para o consumo e o sinal tarifário para o incentivo à mesma.

Foram realizadas duas simulą̧õs do sistema, uma delas com o objetivo de reproduzir a simulação realizada pelo GCPS, em seu ciclo normal de planejamento para operíodo 1992 - 2001. A outra, consistiu num ajuste do programa de obras, considerando uma redução de $5 \%$ na demanda.

\section{1 - SIMULAÇÃO DO SISTEMA PARA ATENDIMENTO DO MERCADO PREVISTO SEM A REDUÇÃO POR EFICIÊNCIA}

Esta simulação consistiu apenas numa repetição da simulação feita no GCPS, pois que, foram considerados os mesmos mercados a cada ano, a mesma carteira de projetos e as mesmas hidraulicidades.

Resultaram desta simulação as condições de atendimento a seguir representadas na Tabela 22.

O programa de obras ajustado contem quatro novas usinas iniciando sua operação em 1997, primeiro ano do período de expansão, seis usinas em 1998, oito usinas em 1999, quatorze usinas no ano 2000, e outras quatorze no ano 2001 (veja Tabela 11).

Resultou da simulação um custo incremental de geração térmica de US\$ 125,24 milhões/ano, um custo de déficit negativo, quer dizer que o risco de $5 \%$ foi superado, com transferências de energia entre as regiões Sul e Sudeste. E, um custo de operação e manutenção de US\$ 56,00 milhões/ano. 
Para o período em questão, embora o déficit esperado tenha resultado negativo, ajustou-se como premissa um custo de déficit de US $\$ 480,00 / \mathrm{MWh}$, resultando num Custo Marginal de Operação de US\$ 39,05/MWh e num Custo Marginal de Expansão de US\$ 46,58/MWh.

A razão entre os custos marginais de expansão e de operação, notada como CME/ CMO representa um parâmetro de controle da simulação do sistema, através do qual é aferida a premissa para otimização da expansão ${ }^{(20)}$.

Observa-se que não há uma coincidência perfeita entre os custos marginais de curto e médio prazos, a relação $\mathrm{CME} / \mathrm{CMO}=1,19$, indicando que poderia ser excluida mais alguma usina no horizonte. Entretanto, isso não foi feito em virtude da indivisibilidade das obras, sendo que a próxima obra, se postergada, resultaria em custo menor do que o custo de curto prazo, em proporção maior do que a diferença acima citada.

A Tabela 23 apresenta os resultados dos cálculos de custos marginais.

Os investimentos necessários ao programa de obras ajustado, totalizam US\$ 13.730,11 milhões a valor presente em janeiro de 1990, com um investimento médio anual da ordem de US\$1.405,97 milhões.

A Tabela 24 apresenta os investimentos necessários por ano e por usina.

As Tabelas 25, 26 e 27 respectivamente, apresentam os cálculos dos custos de O\&M, Déficit e Incremental de Geração Térmica, e, a estimativa do mercado atendido pelas usinas nucleares, conforme foi considerado na simulação.

\section{2 - SIMULAÇÃO DO SISTEMA PARA ATENDIMENTO DO MERCADO PREVISTO COM A REDUÇÃO POR EFICIÊNCIA}

Nessa simulação, obteve-se um mercado menor do que a projeção original, em $5 \%$ durante todo o horizonte da projeção. Tal redução de usos finais apresenta o efeito pretendido de redução do consumo por incremento da eficiência.

O programa de obras recomendado considera apenas uma nova usina em 1997, cinco em 1998, seis em 1999, oito no ano 2000, e, mais sete no ano 2001.

A Tabela 28 apresenta os custos marginais resultantes da simulação; observa-se que 
há uma redução nos custos de geração térmica, déficit e O\&M, resultando também numa redução significativa do custo marginal de expansão (US\$26,75/MWh).

As Tabelas 29, 30, 31 e 32 respectivamente, apresentam os investimentos por usina e por ano, o cálculo do custo de $0 \& \mathrm{M}$, os cálculos dos custos incremental de geração térmica e déficit, e, a estimativa do mercado atendido pelas usinas nucleares.

Considerou-se uma redução global de $5 \%$ no consumo total, tomando por hipótese que este pode ser o resultado das reações dos consumidores ao programa de incentivo à eficiência, com intensidades diferentes em cada classe de consumo.

Entretanto, opercentual de redução propostopode ser graduadode forma diferenciada, ao longo do tempo, ou segundo as classes de fornecimento, e pode também resultar numa redução global menor do que a simulada, resultando ainda numa razoável economia de recursos de capital.

Resultaram desta simulação as condições de atendimento representadas na Tabela 33.

\section{3 - SINAL TARIFÁRIO PARA O INCREMENTO DA EFICIÊNCIA}

A diferença de custos, que é a base para o estabelecimento dos descontos, é uma referência do beneficio esperado, e se refere ao parque gerador.

Tal diferença é: $\mathrm{Cl}-\mathrm{Cl} 1^{\prime}=$ US $\$(46,58-26,75)=$ US $\$ 19,83 / \mathrm{MWh}$

O estabelecimento do desconto pode ser feito em função do nível do sistema, no qual se dá o fornecimento, considerando as perdas elétricas até aquele ponto, bem como as classes de consumo e seus respectivos potenciais de redução. 
A consideração das perdas se faz necessária, para que se tenha uma equivalência dos efeitos das reduções em resposta à sinalização tarifária; ou seja, 1 kWh conservado no nivel de tensão mais elevado do sistema, corresponderá a uma redução, ao nível do parque gerador, menor do que o que corresponderia a redução de $1 \mathrm{kWh}$ ao nivel de baixa tensão do sistema, pois, esta última terá evitado a geração da energia consumida ao longo do sistema, pelo Efeito Joule, no transporte desde o parque gerador até o nivel onde ocorre a conservação.

A ponderação pela razão entre a redução percentual alcançada por determinado consumidor e aquela proposta como média para a classe de consumo na qual se insere o consumidor, tem por objetivo o estabelecimento de uma graduação que incentiva e premia os maiores esforços de conservação.

Assim o desconto seria expresso na forma seguinte:

$$
d=\left(C 1-C 1^{\prime}\right) \times \tau \times \frac{r_{i \%}}{r_{\%}}
$$

onde:

$d=$ desconto em US\$MWh

C1 = custo marginal do programa de expansão normal

$\mathrm{C1}^{\prime}$ = custo marginal do programa reduzido, simulado com uma oferta menor, na proporção da redução

na demanda proposta no programa de conservação

$\tau=$ perdas por Efeito Joule, desde o parque gerador até o nivel do sistema em questão

$r_{\text {iof }}=$ redução percentual obtida pelo consumidor $\mathrm{i}$

$\Gamma_{\%}=$ redução percentual média, "per capita", na classe de consumidores na qual se insere o consumidor i

Observamos que a metodologia acima comentada se fundamenta nos principios da microeconomia, e os resultados que a ela atribuimos se constituem em parâmetros para orientar a prática de tarifas orientadas para a eficiência econômica e energética.

Os resultados dessa prática se refletem em beneficios macroeconômicos, cuja realização depende do grau de adesão ao programa de incremento da eficiência, e cuja avaliação propomos seja feita através da monitoração da tendência do percentual de redução do consumo realizado em relação ao proposto no programa.

A avaliação completa dos resultados de um programa dessa natureza deve considerar apuracões de custos sociais reduzidos, economia de divisas para o Pais, ônus sociais advindos da não realização dos pro:etos, bem como outros efeitos como a redução de impactos ambientais. Certamente a tentativa de uma avaliação completa deve estar suportada por uma gama bem variada de análises.

Considerando ser objeto desta dissertação, principalmente, a identificação de um mecanismo que induza a eficiência, através da sinalização tarifária, não dedicaremos mais tempo a avaliação dos resultados, porém, é oportuno registrar a necessidade de se investir recursos nessas 
avaliações, principalmente com o objetivo de atestar a eficácia da estratégia de incremento da eficiência energética.

Há também outras metodologias que podem ser identificadas, tanto sob o enfoque microeconômico para a valorização do beneficio da redução do consumo, como sob o enfoque macroeconômico; e há também metodologias que se fundamentam em conceitos fisicos e não econômicos. Uma metodologia que considera a produtividade energética do esforço humano na conservação é um exemplo. Apresentam-se no Apêndice B algumas considerações sobre essa metodologia.

\section{A PROPOSTA DE ORIENTAÇÃO DAS TARIFAS COMO UMA FORMA PARA REDUZIR IMPACTOS AMBIENTAIS}

A redução do consumo, ou do crescimento deste, diminui os impactos sobre o meio ambiente; é uma conclusão lógica que pode ser alcançada sob diversos aspectos da análise do sistema energético.

Também diversas são as estratégias já identificadas para a diminuição de impactos ambientais, e dentre elas está a prática de preços que inibam ou ao menos que não incentivem o consumo indiscriminado de energia.

A Proposta de Orientação das Tarifas ora apresentada, pode ser vista como uma aplicação dessa estratégia, na medida que procura induzir os consumidores a uma segregação de seu consumo, identificando uma parcela que pode ser reduzida sem prejuizo para o atendimento de suas necessidades e incentivando essa redução com uma sinalização tarifária que aloca à sua responsabilidade, ao consumir tal parcela, o custo da expansão que poderia ser evitado caso o consumo fosse reduzido naquelas proporções.

Observa-sç, também, que a prática de preços que inibam consumos perdulários é um corolário da teoria da incorporação das externalidades nos preços da energia, ou seja, a consideração dos custos originados no ambiente sócio-econômico cujos agentes não fazem parte diretamente do processo de geração e consumo de energia.

Nas duas últimas décadas, têm sido empreendidos esforços (particularmente pelos ambientalistas) no sentido da identificação e quantificação das externalidades na produção e consumo de energia; seus argumentos consideram o fato de que as politicas energéticas atualmente não consideram aqueles custos sociais, provocando o que tem sido denominado a tragédia do patrimônio 
público, na medida em que o mercado demanda quantidades excessivas de energia, se esta for subvalorizada, e, tais excessos se refletem em também excessivos impactos nos recursos naturais e meio ambiente.

O Departamento de Energia do Governo dos EUA contratou, em 1990, estudos ao Oak Ridge National Laboratory and Resources for The Future para se dispor de estimativas dos custos sociais (externalidades) nas diversas formas de produção de energia.

Para cada ciclo a ser estudado fóssil, urânio ou renovável serão realizadas medidas dos impactos, incluindo necessidades de trabalho, capital e materiais, bemcomo efeitos sobre as qualidades do ar, da água, e, sobre a segurança nacional. Estudos similares estão sendo desenvolvidos pela Comunidade Européia e outras nações.

Além do beneficio da redução de impactos, há também o aspecto da escassez de capital nos paises em desenvolvimento, nos quais a redução do consumo se reflete numa menor aplicação de vultosos recursos em projetos intensivos em capital, como é o caso da infraestrutura, cujo retorno é via de regra lento e vulnerável devido à propria politica de preços dos energéticos nesses paises, permitindo uma maior aplicação de capital $\mathrm{cm}$ projetos de retorno mais rápido. 


\section{CAPÍTULO IV}

\section{CONCLUSÕES}

Talvezuma das principais conclusões que se pode alcançar com a presente dissertação seja a de que uma politica tarifária pode conter orientą̧ões bastante claras para a cficicincia dos usos finais e também da oferta de energia.

A proposta de orientação de tarifas discutida no Capitulo III ć um exemplo, cuja análise permite a idéia de diversificação de mecanismos que induzam ações de consumidores e produtores ou distribuidores de energia, orientadas para a eficiência econômica c encrgética.

A teoria do equilibrio formulada por Paretoconstitui-sena base conceitual sistematizada para a conservação de energia, e portanto, pode ser tomada como suporte para os diversos mecanismos de indução a eficiência acima comentados.

A partir do estudo do caso do Setor Elétrico Brasileiro, considerado nas discussões aqui apresentadas, foi possivel recomendar o atributo da coerência da politica tarifária com a política energética como um dos princípios básicos para a fixação de tarifas, como forma de facultar ao respectivo processo decisório, em todos os seus niveis, a prática de politicas de preços voltadas para a eficiência energética. Nesse sentido, há que se ressaltar que as metodologias mais adequadas a esse principio básico de coerência, são aquelas dotadas de razoável e consistente alocação de custos ao longo do sistema elétrico, e, conforme o comportamento dos usuários do sistema.

Partindo para os aspectos da prática tarifária observada no setor elétrico brasileiro, foi possivel evidenciar um fato importante: a prática de niveis tarifários artificialmente baixos virtualiza o senso econômico do custo da eletricidade para a própria sociedade, além de facilitar consumos perdulários.

Os efeitos indesejáveis dessa prática são canalizados para a sociedade através das concessionárias de energia elétrica, que se encontram com suas estruturas de capital descquilibradas, produzindo eletricidade a custos elevados em decorrência da carga de custos financeiros, e, praticamente sem condições financeiras para empreenderem a expansão do sistema de forma a atenderem suas demandas.

As graves dificuldades econômico-financeiras do setor elétrico nacional têm solução dependente de reformulações em sua regulamentação, nesse sentido vários esforços se empreendem, com os primeiros tendo partido da própria iniciativa do setor; os principais foram a Portaria do Ministério das Minas e Energia (MME) №. 364, de 1984, que determinou abrangente diagnóstico e formulação de soluções para os principais problemas econômico-financeiros, e, a Revisão Institu- 
-cional do Setor Elétrico Nacional (REVISE) instituida pelo poder concedente em 1987, que congregou cerca de setecentos técnicos de diversas empresas e órgãos em torno dos esforços de rever e formular uma nova estrutura institucional para o setor.

Mas todos esses esforços não culminaram em alterações efetivas; parece mesmo que essas alterações serão propostas e implementadas através do Congresso Nacional, o que talvez seja o caminho mais lógico para a sociedade ter organizado o suprimento de eletricidade de que necessita.

Apresentadas a base conceitual dos preços de energia, c a prática tarifária observada no setor elétrico brasileiro, completou-se um contexto para o qual foi proposto um mecanismo para refletir nas tarifas sinais orientativos para a eficiência.

O conceito dessa orientação de tarifas consiste em sinalizar ao consumidor e ao produtor de energia o maior valor de uso da eletricidade em determinado nível de tensão e em determinado tempo, ao menor custo possivel para a sociedade. Tal conceito incorpora também a idéia de regular a demanda por novas capacidades no sistema elétrico, liberando recursos de capital para aplicações de retorno mais rápido do que na infraestrutura de energia elétrica.

A orientação de tarifas proposta consiste no estabclecimento de padrões de consumo considerados eficientes, bem como de metas de redução para atingi-los, sendo colocada em forma clara nas contas dos consumidores, o valor econômico da parcela de seu consumo que poderia ser reduzida em prol de uma maior eficiência em seus usos finais.

A consecução do enquadramento dos consumos em padrões de eficiência resulta em beneficios percebidos em primeiro plano pelos próprios consumidores, na medida em que gastarão menos recursos financeiros para consumir eletricidade, e num segundo plano toda a sociedade se beneficia, porquanto haverá uma frenagem nas necessidades de expansão do sistema, tendo que aplicar menores quantidades de recursos de capital para o atendimento de suas necessidades. Esse enquadramento depende dos próprios consumidores, revendo suas instalações, equipamentos e hábitos, mas também da indústria de equipamentos, da qual se espera que coloque no mercado equipamentos elétricos de menor consumo especifico relativamente aos atuais.

Finalmente, há que se ressaltar quea orientaçãode tarifas propostaé também coerente com a desejável redução de impactos ambientais decorrentes da produção de eletricidade, que particularmente no Brasil se traduz em inundações de terras para formar reservatórios para o parque gerador. Em menor escala haverá impactos também na atmosfera, considerando o fato de que estão previstas algumas usinas térmicas nas regiões sul e sudeste.

É também coerente, na medida em que inibe consumos perdulários e permite, na graduação do sinal tarifário a ser estabelecido, a incorporação de externalidades nos preços da energia ofertada. 


\section{ANEXO I \\ EXPRESSÕES MATEMÁTICAS PARA O CÁLCULO \\ DO CUSTO DO INVESTIMENTO}

\section{A) A PARTIR DOS PROGRAMAS DE OBRAS}

$$
\mathrm{Ca}=\sum_{1}^{m} \mathrm{Caj}
$$

onde:

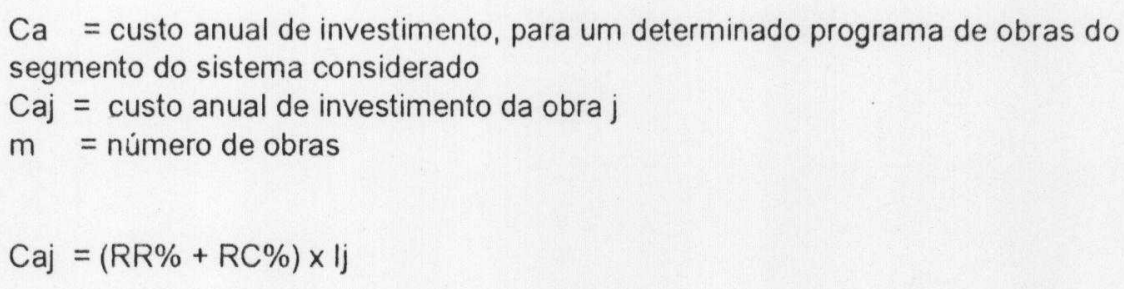

onde:

$$
\begin{aligned}
& \text { (RR\% + RC\%) = percentuais relativos à remuneração e à recuperação do capital } \\
& \text { investido } \\
& \text { lj }=\text { valor presente do somatorio dos investimentos feitos na usina j } \\
& \mid j=\sum_{k=m}^{p} l j k(1+i)^{-k}
\end{aligned}
$$

onde:

$$
\begin{aligned}
& \text { ljk }=\text { desembolso anual para a obra } j, \text { no ano } k \\
& (1+i)^{k}=\text { fator de recuperação de capital calculado à taxa } i \\
& k \quad=n \text { até } p, \text { período de desembolsos considerado no programa de obras }
\end{aligned}
$$

\section{B) A PARTIR DOS CUSTOS MODULARES APLICADOS SOBRE AS TENDENCIAS DE CRESCIMENTO DE AGREGADOS FÍSICOS.}

$$
\mathrm{Ca}=\left[\sum_{i=4}^{n} \mathrm{Qi} \times \mathrm{CMi}\right] \times(\mathrm{RR} \%+\mathrm{RC} \%)
$$

onde:

$\mathrm{Ca}=$ custo anual do investimento para expansão do segmento do sistema considerado

$\mathrm{Qi}=$ quantidade esperada para expansão do agregado físico i obtida através de projeções de séries históricas, explicadas por variáveis físicas como potência ( $\mathrm{kW}$ ) ou consumo (MWh) 
$\mathrm{CMi}=$ custo modular do agregado físico $\mathrm{i}$

$i=$ agregado físico, que pode ser: quantidade de quilometros de uma rede $(\mathrm{km})$, quantidade de capacidade instalada (kVA), quantidade de transformadores, etc

$Q i=a \times \frac{x_{i}}{p}$

onde:

$a=$ variável adimensional, definida a partir das expressões que explicam o crescimento exponencial das quantidades de agregados fisicos, em função do crescimento da potência demandada, ou, do consumo (Leis de Quantidades de Obras - LQO) $)^{(i x)}$.

$X i=$ tipo de agregado físico de obras

$P=$ potência demandada na ponta. 


\begin{tabular}{|c|c|}
\hline \multicolumn{2}{|c|}{ Percentuais do Custo do Investimento Relativos a } \\
\hline Segmentos de Redes & $\%$ O\&M - anual \\
\hline Interconexão & 0.6 \\
\hline \multicolumn{2}{|l|}{ Repartição } \\
\hline Linhas & 0.6 \\
\hline Postos de Transformação & 1.4 \\
\hline Transformadores & 0.3 \\
\hline \multicolumn{2}{|l|}{ Distribuição } \\
\hline Subestações AT/MT & 1.0 \\
\hline Rede de Média Tensão & 1.0 \\
\hline Rede de Baixa Tensão & 2.0 \\
\hline
\end{tabular}

Fonte: DNAEE - Departamento Nacional de Águas e Energia Elétrica

No caso do parque gerador, existem fórmulas empíricas que têm sido adotadas para representar esses custos conforme a seguir indicado:

$$
\operatorname{Cos}_{k}^{\operatorname{On}}=\gamma \cdot P
$$

ou

$$
\mathrm{C}_{k}^{\mathrm{O} M}=p \cdot I
$$

onde:

$$
\begin{aligned}
& \mathrm{C}_{k}^{\mathrm{Oam}}=\text { custo anual de operação e manutenção relativo às novas obras } \\
& \mathrm{P} \quad=\text { potência instalada } \\
& \text { I = investimento em valor presente } \\
& \text { - } \gamma \text { e } \rho=\text { valores empíricos }
\end{aligned}
$$




\section{ANEXO III}

\section{AJUSTE DA TARIFA EM RELAÇÃO AOS CUSTOS MARGINAIS DOS FORNECIMENTOS TIPICOS}

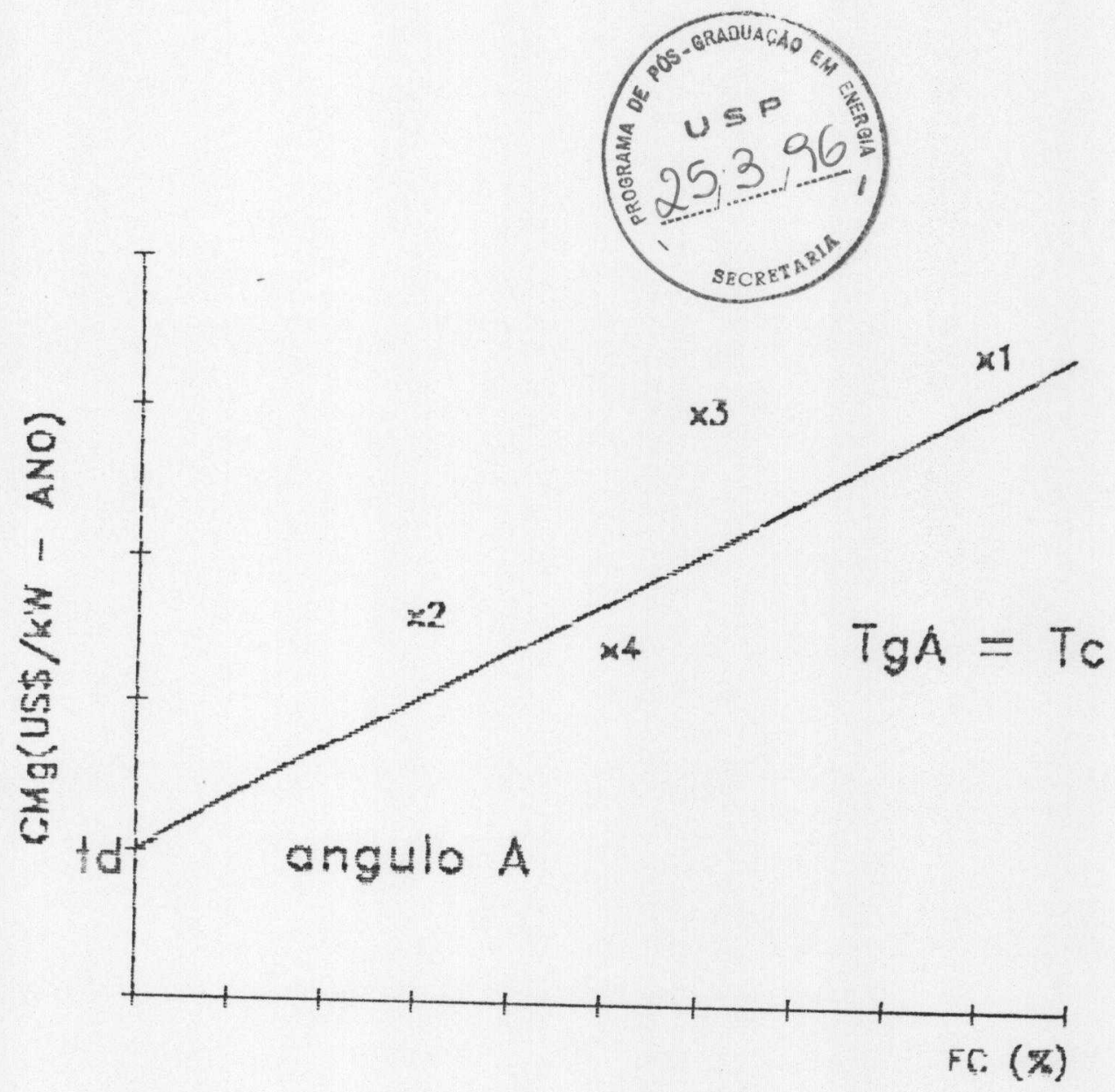

onde:
$\mathrm{td}=$ tarifa de demanda
tc $=$ tarifa de consumo

$\mathrm{CMg}(\$ / \mathrm{kW}$-ano $)=$ escala de custos marginais, contemplando os valores especificos de cada fornecimento-tipo

$\mathrm{FC}(\%)=$ escala de fatores de carga, contemplando os valores especificos de cada fornecimento-tipo 


\section{NOTAS}

(01) A obra é composta por cinco Livros, no Livro Primeiro, Capitulo V, estão contidas suas colocações sobre a formação de preços de mercadorias.

(02) Os Capitulos I e XXX de sua obra Princípios de Economia Politica e Tributação contém suas teorias sobre a formação e a dinâmica dos preços.

(03) Conceito definido na maioria dos trabalhos dos pensadores clássícos.

(04) Esta citação particularmente referencia-se à sua obra Salário, Preço e Lucro.

(05) William Stanley Jevons, em sua obra A Teoria da Economia Politica, no Capitulo IV, apresenta a sistematizą̧ão matemática da teoria da troca.

(06) Cournot e Dupuit elaboraram a teoria econômica do monopólio, com instrumentação matemática clara e precisa. Cournot escreveu sobre o monopólio no capitulo $\mathrm{V}$ de sua obra intitulada Pesquisas Sobre os Principios Matemáticos da Teoria das Riquezas, publicada em 1838; e, Dupuit escreveu sobre o monopólio em duas memórias, uma intitulada A Medida da Utilidade dos Trabalhos Públicos, e outra, Pedágios na Utilidade das Vias de Comunicą̧ão publicadas respectivamente em 1844 e 1849.

(07) Rapport a la session speciale de la Comission de Tarifacation de L'UNIPEDE, le 9 et 10 mai 1969.

(08) Denomina-se Ativos os bens, valores, créditos e semelhantes, que formam o patrimômio de uma empresa.

(09) Denominam-se Passivos as dividas e obrigações de uma empresa.

(10) M. Ciddayao tem trabalhado na análise de experiências de politicas de preços em diversos paises em desenvolvimento, tendo concluído sobre a importância de políticas de preços da energia.

(11) Tivemos oportunidade de ouvir diversas manifestações a respeito, durante o V Congresso Latino Americano y del Caribe sobre Tarifas de Energia Elétrica, realizado em Caracas, setembro de 1987 quando um dos temas mais debatidos foi a experiência da utilização de custos marginais como base para tarifas.

(12) Em realidade o custo implicito do déficit não é constante, pois, depende das condições e estratégias de operação do sistema. Entretanto, face à dificuldade para uma maior aproximaçãoda realidade, adota-se por simulação o custo implicito do déficit como sendo uma constante.

(13) O conceito e caracteristicas de sistema eletroenergético auto sustentável são discutidos com grande especificidade pelo Prof. José Goldemberg, na publicação Energy for a Sustainable World, da qual é co-autor. 
(14) Os projetos de usinas hidroelétricas que têm sido financiadas total ou parcialmente com recursos do Banco Mundial (BIRD) apresentam-se com tempo de construção projetado, variando de três a doze anos, com uma média de 5,7 anos.

(15) Segundo Araújo, há uma relação aproximada a uma exponencial entre o aumento do custos e o aumento da complexidade da informação.

(16) A Fundação João Pinheiro, de Belo Horizonte-MG, tem patrocinado estudos sobre o impacto de preços públicos nos índices que medem a inflação, cujos resultados tem indicado que para um aumento de cerca de $10 \%$ nas tarifas de energia elétrica resultam impactos de $0.2192 \%$ no Índice Geral de Preços (IGP) ou $0.4252 \%$ no Índice de Custo de Vida de metrópoles como o Rio de Janeiro.

(17) O planejamento da expansão do sistema gerador brasileiro baseia-se atualmente na pré-fixação do risco anual de déficit de energia. Nessa linha, pré-fixa-se o nível de risco e minimiza-se o custo esperado da operação, de forma que a estratégia adotada para gerir a operação do sistema atende a esse nivel de confiabilidade.

(18) As empresas estatais têm maior facilidade de acesso ao crédito, devido à garantia do Estado; entretanto, o endividamento excessivo provocou um racionamento de crédito e ampliou o risco de insolvência. A combinação desses dois fatores reduziu a capacidade de empréstimo das empresas de energia elétrica e freiou os investimentos.

(19) Rodrigues, A.P. (COPPE/AIE, Rio de Janeiro) Comunicação Pessoal, 1990.

(20) A razão entre os custos marginais de expansão e operação CME/CMO é um indicador da adequação do parque gerador à carga. Idealmente essa razão deve ser igual 1,0; quando menor do que 1,0 indica que há a necessidade de expandir o sistema para se obter o custo mínimo de geração; quando maior do que 1,0 indica que a expansão do mesmo está adiantada em relação às necessidades do mercado. 


\section{REFERÊNCIAS BIBLIOGRÁFICAS}

(i) Smith, A. A Riqueza das Nações - Investigação sobre sua Natureza e Causas, comentários de Edwin Cannan, traduzido por Luiz João Baraúna, Victor Civita, ed., São Paulo, 1983.

(ii) Ricardo, D. Princípios de Economia Política e Tributação, com comentários de Piero Sraffa e M.H.Dobb, traduzido por Paulo Henrique Ribeiro Sandromi, Victor Civita, ed., São Paulo, 1982.

(iii) Marx, K.H. Salário, Preço e Lucro, com comentários de Jacob Gorender, traduzido por Edgard Malagodi et al, Victor Civita, ed., São Paulo, 1982.

(iv) Jevons, W.S. A Teoria da Economia Política, com comentários de F.A.Hayek, traduzido por Luiz João Baraúna, Victor Civita, ed., São Paulo, 1983.

(v) Walras, L. Compêndio dos Elementos de Economia Política Pura, com comentários de Dionísio Dias C. Netto, traduzido por João Guilherme Vargas Neto, Victor Civita, ed., São Paulo, 1984.

(vi) Pareto, V. Manual de Economia Política, traduzido por João Guilherme Vargas Netto, Victor Civita, ed., São Paulo, 1984.

(vii) Marshall, A. Princípios de Economia Polílitca, com comentários de Ottolmy Straauch, traduzido por Romulo Almeida e Ottolmy Strauch, Victor Civita, ed., São Paulo, 1982. (viii) ELETROBRAS, Revisão Institucional do Setor Elétrico Brasileiro, Rio de Janeiro,
1989. (ix) DNAEE, Nova Tarifa de Energia Elétrica - Metodologia e Aplicação, Brasília,
1985.

(x) EPRI, Innovative Rate Design Survey: 1986, New York, 1988.

(xi) Mello, C.A.B de, Prestação de Serviços Públicos e Adminsitração Indireta, Editora Revista dos Tribunais, São Paulo, 1983.

(xii) Martinez-Alier, J., Ecological Economics, T.J. Press (Padstown) Ltd., Great Britain, 1990.

(xiii) Fortunato, L.A.M., et al Introdução ao Planejamento da Expansão e Operação de Sistemas de Produção de Energia Elétrica, Universidade Federal Fluminense - Editora Universitária, Niterói, 1990. (xiv) Goldemberg, J., et al Energy for a Sustainable World, Wiley Eastern Limited, ed.,
New Delhi, 1988.

(xv) GCPS, Manuais de Operação do Modelos.

(xvi) Araújo, J.L.R.H., Modelos de Energia para Planejamento, Núcleo de Documentação e Informação em Energia - NDIE - COPPE/AIE, ed., Rio de Janeiro, 1988. 


\section{APÊNDICE A \\ CÁlCULO DO CUSTO MARGINAL DE EXPANSÃO}

\section{- CONCEITOS E METOdOLOGIA -}

A gestão do sistema para o atendimento das demandas crescentes considera duas possibilidades: (a) a expansão do mesmo, aumentando sua capacidade instalada, ou (b) o incremento de sua operação, aumentando a geração termoelétrica e aumentando o risco de déficit, porém não aumentando a capacidade instalada.

A escolha da melhor alternativa dependerá das condições de atendimento do sistema, compreendendo capacidade instalada, hidraulicidade no periodo, participação de geração térmica no atendimento e o risco de déficit.

O cálculo do custo marginal resulta da avaliação econômica do impacto do atendimento da demanda adicional, ou seja, marginal, nas consdições de atendimento do sistema, que podem ser verificadas em simulações do sistema atendendo às demandas projetadas.

Assim, antes de se escolher a melhor alternativa faz-se a avaliação econômica do sistema, que corresponde ao custo de atendimento, em ambas as possibilidades.

O custo resultante da simulação do sistema, que considera a expansão de sua capacidade instalada, é denominado custo marginal de expansão, ou, custo marginal de longo prazo.

O custo resultante da simulação do sistema, que apenas considera o incremento de sua operação, sem considerar uma nova configuração do mesmo, com mais usinas, é denominado custo marginal de operação, ou custo marginal de curto prazo.

A diferença entre os custos totais sem e com expansão, $\mathrm{DC}(\mathrm{q})$ é nula nesses pontos de ótimo. Essa condição implica também na derivada da função ser nula naqueles pontos.

$$
\frac{d D C(q)}{d q}=0
$$




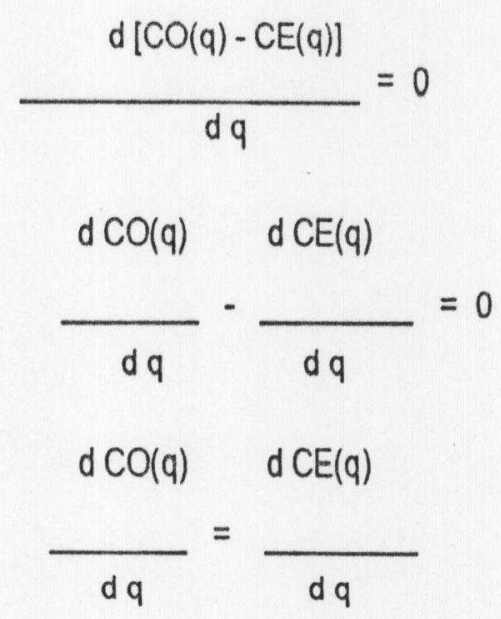

ou seja, nos pontos de ótimo da gestão do sistema os custos margínais de operação e de expansão são iguais.

Então, na prática o que se faz é simular diversas alternativas de configuração do sistema, buscando encontrar uma que mais se aproxime de um ponto de ótimo, para o mercado que se tem para atender.

Essas simulações são feitas com modelos computacionais que representam o sistema em funcionamento, basicamente verificando se a energia e a potencia geradas em cada usina, considerando a capacidade de transmissão do sistema, conseguem, ou melhor, são suficientes para atender ao mercado projetado, o qual também é representado por demanda (MW) e energia (MWh).

Assim, no sistema interligado brasileiro, que abrange as bacias dos rios Paraná, Paraguai e Uruguai, que juntas compoem, a bacia Platina, a modelagem se inicia por selecionar um conjunto de obras de menor custo dentre os projetos em carteira, estejam eles em quaisquer das bacias, o modelo nesta fase é denominado DSELP.

Eleito esse conjunto de obras, define-se um cronograma tentativo para a entrada em operação das mesmas no periodo considerado; e, com o auxilio de um outro modelo, o GERASER, são geradas cerca de 2000 séries sintéticas de possíveis afluências hidràulicas (chuvas) ao sistema, sendo que para cada uma delas é feita a sequência de decisões de geração para cada usina no periodo considerado, de forma que o armazenamento nos reservatórios seja otimizado e sejam despachadas gerações térmicas no mínimo possivel.

Essa sequência de decisões de geração é feita em duas etapas; numa primeira, é considerado todo o sistena como uma usina equivalente, posteriormente considerando sistemas equivalentes no Sul e no Sudeste/Centro Oeste, e, finalmente considerando cada usina em separado.

A simulação se completa com uma análise da confiabilidade do sistema, através do modelo CONFGER, quando é calculada a probabilidade de perda de carga (LOLP - Lost of Load Probability). 
As simulações se repetem, seguindo ajustes no conjunto e cronograma de obras, até que se consiga atender ao mercado, em 1900 das 2000 probabilidades de afluências, ou seja, admitindo-se $5 \%$ de probabilidade de se ter déficit no atendimento.

Para a configuração que corresponda a esse ajuste, calcula-se o custo marginal, a partir da razão entre as variações anuais a valor presente, do custo da geração térmica, custo do déficit e custo do investimento e da operação e manutenção, e, a variação da carga também a valor presente.

Esse cálculo é feito com relação a cada ano j do periodo da expansão, qual seja do $6^{\circ}$. ao $10^{\circ}$. ano; especificamente em relação ao custo de O\&M, o cálculo é feito por usina a cada ano.

A expressão a seguir ilustra esse cálculo

$$
C M E=\frac{V P(/ \Delta C G T)+V P(\Delta C D)+V P(C I+C O M)}{V P(\Delta q)}
$$

onde:

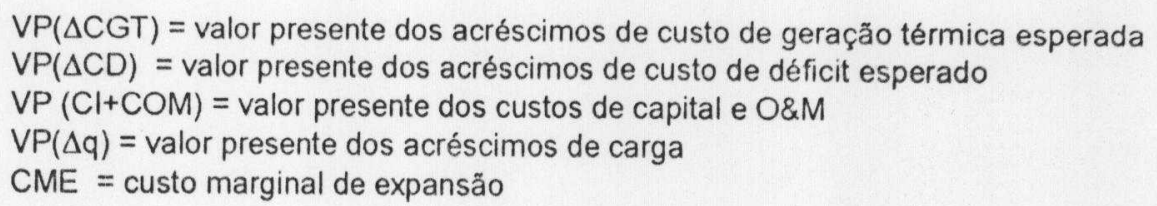

No Capitulo I desta dissertação já foi apresentada essa composição e definição das parcelas.

O Quadro A emanexo apresenta uma síntese dos modelos e funções que desempenham na simulação do sistema.

O valor presente do acréscimo de custo de geração térmica esperada VP( $\triangle C G T)$, resulta da verificação de quanto combustível será gasto a mais para atender ao mercado, com a simulação do sistema na configuração ajustada.

Esse cálculo é feito com base nas quantidades anuais de combustível adicional, valorizadas aos respectivos preços, acrescidos de demais despesas variáveis das usinas térmicas, considerando o periodo de anos no qual o sistema estará sendo expandido.

$$
\operatorname{VP}(\Delta C G T)=\sum_{j=1}^{n}\left[\frac{\Delta C G T j}{(1+i)^{\prime}}\right]
$$

onde: .

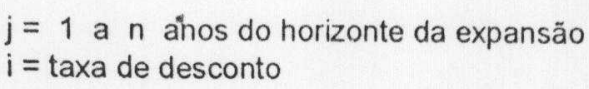

Similarmente, o cálculo do valor presente da variação do custo de déficit resulta da verificação da variação da probabilidade de déficit, valorizada com base no conceito de que seu valor 
estabelece um compromisso entre custos operativos e qualidade do suprimento de energia.

Há dois enfoques para o cálculo da variação do custo do déficit: (a) um que considera seu custo social, ou seja, o impacto causado pelo não atendimento, nas diferentes atividades econômicas do pais; e, (b) outro que considera um índice pré-fixado de qualidade de suprimento, considerado adequado para as decisões do planejamentoda expansão e operação, e, com base nele determina-se a disponibilidade de energia no sistema, que se for menor do que a demanda, resultará numa parte não atendida, que por sua vez será valorizada com base no próprio custo da energia que pode ser produzida

$$
V P(\triangle C D)=\sum_{j=1}^{n}\left[\frac{\Delta C D i}{(1+i)^{j}}\right]
$$

onde :

$$
\begin{aligned}
& j=1 \text { a } n \text { anos do periodo da expansão } \\
& i=\text { taxa de desconto }
\end{aligned}
$$

O valor presente dos custos anuais de investimento e dos custos de operação e manutenção das novas unidades geradoras é calculado de forma similar; chama-se a atenção para o fato de que está convencionado que o periodo de anos para o qual se busca os dados de investimentos e de variações da operação e manutenção vai do $6^{\circ}$. ao $10^{\circ}$. ano.

É assim considerado porque o primeiro ano à frente, para o qual é possível tomar-se hoje a decisão de atender a oferta com novas usinas é o $6^{\circ}$. ano; considera-se que cinco anos é o prazo rażoável para se decidir pela construção de uma nova obra e colocá-la em operação.

Assim:

$$
\operatorname{VP}(\Delta C l)=\sum_{j=1}^{5} \Sigma_{k}^{n(j)}\left[\Delta I_{k j} x \frac{F R C}{(1+i)^{j}}\right] \quad \text { US\$/ano }
$$

onde:

I = investimento total na usina $k$, inclusive juros durante a construção, a qual se planeja comissionar no ano $\mathrm{j}$

$\mathrm{FRC}=$ fator de recuperação de capital, à taxa de desconto $i$ da usina $k$

$i=$ taxa de desconto

$\mathrm{j}=$ ano do periodo da expansão $\left(6^{\circ}\right.$. ao $10^{\circ}$. anos $)$

$\mathrm{k}=$ usina a cada ano

onde:

$$
V P(\Delta C O M)=\sum_{j=1}^{5} \sum_{k=1}^{n}\left[\frac{C O M}{k_{j}}\right]
$$

COM = custo de operação " e manutenção da usina $k$, no k,j ano j

$\mathrm{i}=$ taxa de desconto

$\mathrm{k}=\mathrm{usinas}$ novas a cada ano

$\mathrm{j}$ = anos do periodo da expansão 


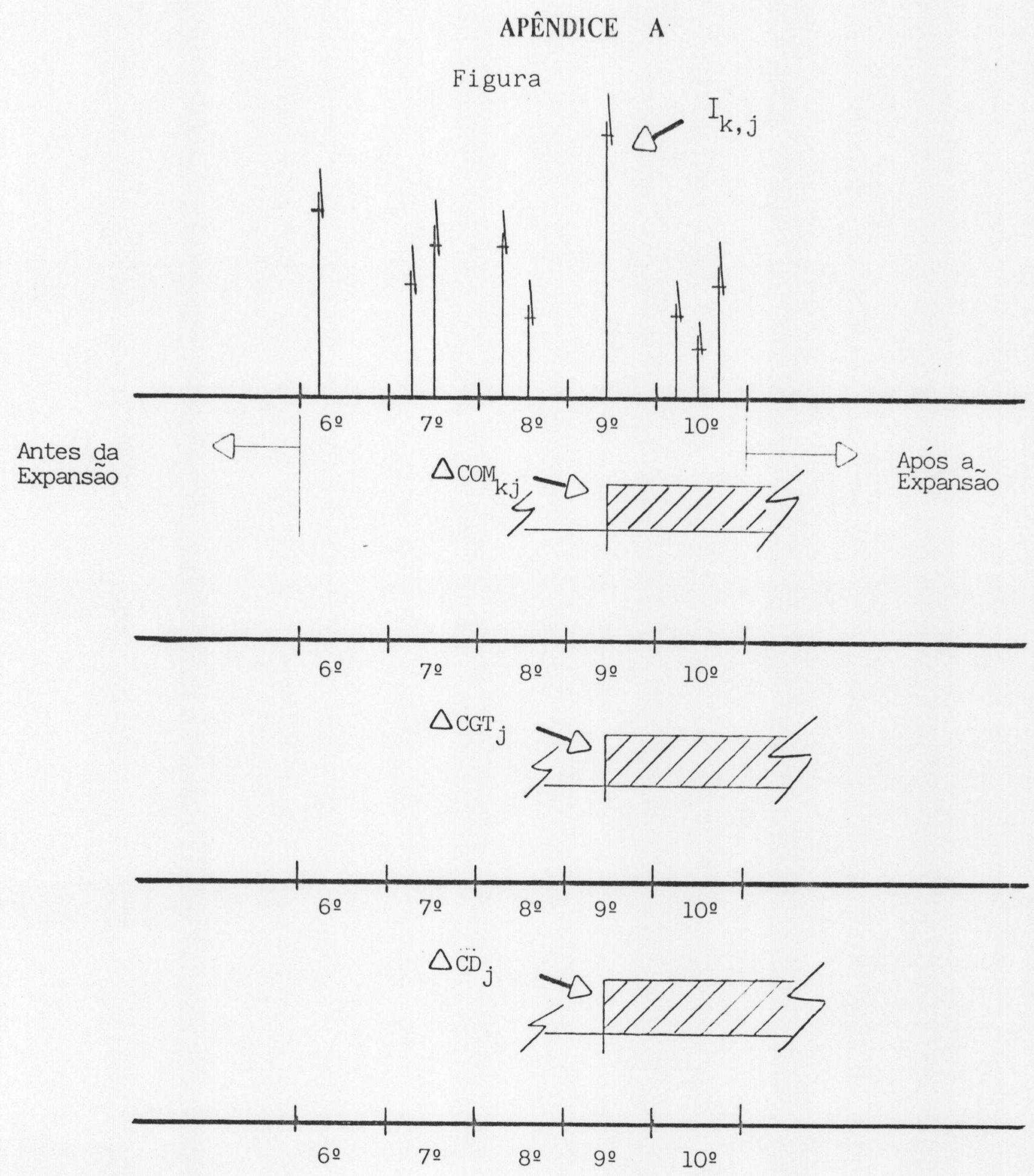

Periodo de Expansão

Fig. A - Parcelas do Custo Marginal de Geração

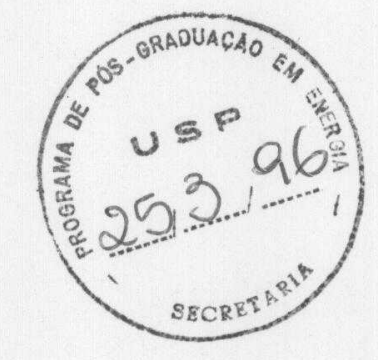




\section{APÊNDICE A}

\begin{tabular}{|c|c|}
\hline \multicolumn{2}{|c|}{ MODELOS EMPREGADOS NA SIMULAÇÃO DO PARQUE GERADOR } \\
\hline MODELO & FUNÇÃO \\
\hline DESELP & $\begin{array}{l}\text { - Analisa Alternativas de Bacias } \\
\text { - Seleciona a alternativa de menor custo } \\
\text { - Ordena os projetos cronologicamente }\end{array}$ \\
\hline DINÂMICA & $\begin{array}{l}\text { - Formula cronograma tentativo para entrada em } \\
\text { operação das máquinas }\end{array}$ \\
\hline GERASER & $\begin{array}{l}\text { - Gera séries sintéticas de afluências hidráulicas } \\
\text { ao sistema }\end{array}$ \\
\hline MSSSE & - Simula a operação a sistema equivalente \\
\hline MISS & - Simula a operação a usinas individualizadas \\
\hline CONFGER & $\begin{array}{l}\text { - Analisa a confiabilidade do sistema, calcula } \\
\text { a LOLP }\end{array}$ \\
\hline
\end{tabular}

Notas: a) Os manuais desses modelos computacionais encontram-se disponíveis na biblioteca do Instituto de Eletrotécnica e Energia da USP.

b) Veja referência bibliográfica $\mathrm{XV}$, sobre esses modelos computacionais. 


\section{APÊNDICE B \\ VALOR ENERGÉTICO DO ESFORÇO HUMANO}

Essa metodologia busca estabelecer um valor em energia para o esforço que os agentes econômicos participantes do sistema energético empreendem, conservando energia.

A linha de argumentos que a embasa não segue o clássico raciocínio microeconômico. Tem seus fundamentos numa espécie de Escola Austriaca de economistas ecólogos.

Os representantes dessa escola, Pfaundler (1839-1920), Josef Popper (1838-1921), Match (1838-1916), Boltzman (1844-1906), e, um dos primeiros autores que escreveram sobre energia e a sociedade humana, Eduard Sacher (1834-1903), se alinhavam com a idéia de que a riqueza de uma nação é basicamente determinada pelo produto energético da energia humana aplicada em seu sistema produtivo. Também, expressaram algumas idéias sobre a distribuição do surplus energético (o produto excedente às necessidades básicas de sobrevivência da sociedade), tendendo a considerar injustos alguns princípios do capitalismo.

Eduard Sacher escreveu dois livros, um deles, intitulado Foundations of a Mechanics of Society, foi editado em 1881 pela respeitável editora de Gustav Fisher, em Jena.

Nesse livro, Sacher define três tipos de valores, todos eles em termos de energia: (a) o valor de uso, (b) o valor de troca, e, (c) o valor especifico.

$\mathrm{O}$ valor de uso corresponde à energia útil proporcionada por determinada atividade, como pode ser a agricultura em determinada área de terras, uma determinada indústria, uma residência, enfim, uma atividade ou objeto e instalação fisica caracterizada.

O valor de troca corresponde à energia humana gasta ou aplicada na atividade, para que a mesma resulte no produto energético útil acima identificado.

E o valor especifico corresponde à razão entre o valor de uso e o valor de troca. É de fato a produtividade do esforço humano.

Um Exemplo: Na Prússia, um mineiro produz, em média, 198 toneladas de Carvão anualmente.

Se o trabalho diário do mineiro equivale a $750 \mathrm{kCal}$, com uma jornada anual de 300 dias de trabalho, o mesmo terá gasto $225.000 \mathrm{kCal}$, significando $1.136 \mathrm{kCal}$ por tonelada de Carvão.

O equivalente calórico de 1 tonelada de Carvão é de $6.500 .000 \mathrm{kCal}$ (sua entalpia), mas com a eficiência de seu uso, o valor de uso fica em $180.000 \mathrm{kCal}$. 
Então, o valor de uso da produção anual de carvão de um minciro é de $3,564 \times 10^{10}$ $\mathrm{kCal}$; para um valor de troca de $2,25 \times 10^{5} \mathrm{kCal}$, resultando num valor especifico de 158 .

Sacher com essas definições expressou o princípio de Podolinsky, no qual os homens são comparados a máquinas, na medida em que compara em uma mesma base, a energia, o consumo e o produto de seu trabalho.

Com base nessas definições, levanta-se a questão de que a conservação de energia em determinada atividade, significa um aumento de produtividade do esforço humano; isto certamente ocorre, pois, ao analisarmos a cadeia de atividades relacionadas com determinada atividade, podemos concluir que em todos os seus segmentos cabe a idéia de se reduzir o input de energia humana, para obter o mesmo output energético, através do aumento de eficiência.

Assim, chamando de d\% esse aumento percentual de eficiência, e de Ce o valor específico da energia em uma determinada atividade, temos que o esforço pelo aumento da eficiência poderia ser expresso assim:

$$
\xi=\operatorname{Ce} \times d \%
$$

e o valor $v$ desse esforço para a nação, seria:

$$
v=\mathrm{C} \times \xi
$$

onde:

$$
\begin{aligned}
& \text { C - é o consumo padrão de energia para a determinada atividade } \\
& \text { em determinado periodo. } \\
& \xi \text { - é o esforço calculado como acima, tomando por base Ce ajustado } \\
& \text { ao consumo padrão C e d\% a diferença percentual de eficiência, } \\
& \text { equivalente à redução ou diferençà percentual do consumo verificado } \\
& \text { em relação ao consumo real. }
\end{aligned}
$$

Assim, o valor $v$ constatado em determinado periodo de medição do consumo de um consumidor, por exemplo 1 mês, ser-lhe-ia devolvido sob a forma de energia em periodo futuro.

O conceito do valor específico Ce se equivale ao do coeficiente de intensidade de energia, citamos a metodologia utilizada em 1979 pelo Grupo de Energia do IFUSP, com base numa análise de Insumo-Produto.

Em sua análise, aquele grupo construiu uma Matriz de Energia, cujos elementos representam as quantidades fisicas de energia, por fonte energética, dispendidas na produção de cada produto da economia.

Para construir essa matriz, partiu-se de duas outras; a matriz de coeficientes de consumo direto mais indireto, cujos elementos representam as razões entre as quantidades monetárias de cada produto i consumidas direta e indiretamente na produção de um outro produto j; e, a matriz de quantidade de energia por unidade monetária, que por sua vez foi calculada a parü dos preços básicos e dos calores de combustão de cada fonte energética. 
Embora conceitualmente equivalente ao Coeficiente de Intensidade de Energia (CIE) definido no trabalho daquele grupo, o Valor Especifico Ceé na realidade uma grandeza adimensional, pois resulta da razão entre duas quandidades de energia, aquela gasta na atividade e aquela outra resultante da mesma.

Considerando a inexistência de uma expressão do produto de uma nação em quantidade de energia, ou melhor, considerando a subjetividade dessa expressão, pensamos que os valores Ce's poderiam ser obtidos a partir dos CIE's.

Praticamente, isso significa adotar para Ce os valores dos coeficientes de consumo direto mais indireto cuja matriz é a mesma utilizada no cálculo dos CIE's. 
T A B E L A S 
Tabela 4

COMPARAÇÃO INTERNACIONAL DE TARIFAS

\begin{tabular}{|c|c|c|c|c|c|c|c|c|}
\hline \multirow{2}{*}{$\begin{array}{l}\text { CLASSE DE } \\
\text { CONSUMO }\end{array}$} & \multirow[t]{2}{*}{ Avo } & \multicolumn{2}{|c|}{ MENOR TARIFA } & \multicolumn{2}{|c|}{ MÉDIA } & \multirow{2}{*}{$\begin{array}{l}\text { MAIOR } \\
\text { PAÍs }\end{array}$} & \multirow{2}{*}{$\frac{\text { TARIFA }}{\text { USS/MWh }}$} & \multirow{2}{*}{$\begin{array}{l}\text { BRASIL } \\
\text { USS/MWh }\end{array}$} \\
\hline & & PAís & USS/MWh & PAÍS & USS/MWh & & & \\
\hline \multicolumn{9}{|l|}{ RESIDENC. } \\
\hline & 1973 & NORUEGA & 16 & ITÁLIA & 33,41 & BÉLGICA & 59,78 & 54,59 \\
\hline & 1979 & GHANA & 22,25 & JAPÃO & 63,07 & BELGICA & 138,47 & 58,43 \\
\hline & 1980 & GHANA & 22,25 & PORTUGAL & 79,51 & BÉLGICA & 156,15 & 50,17 \\
\hline & 1981 & EUA & 30,7 & PORTUGAL & 78,4 & BÉLGICA & 129,64 & 52,2 \\
\hline & 1982 & EUA & 31,35 & JAPÃO & 80,07 & CHIIE & 126,6 & 54,9 \\
\hline & 1983 & NORUEGA & 31,28 & ESPANHA & 70,25 & JAPÃO & 109,93 & 38,94 \\
\hline & 1984 & NORUEGA & 36,04 & ITÁLIA & 68,23 & JAPÃO & 111,67 & 36,55 \\
\hline & 1985 & BRASL & 25,14 & ISRAEL & 63,28 & JAPÃO & 102,67 & 25,14 \\
\hline & 1986 & BRASIL & 25,38 & AUSTRÁLIA & 72 & JAPÃO & 129,62 & 25,38 \\
\hline & 1987 & MÉXICO & 24,78 & SUIÇA & 83,32 & JAPÃO & 152,95 & 48,54 \\
\hline & 1988 & BRASIL & 34,5 & EUA & 98,15 & JAPÃO & 174 & 34,5 \\
\hline & 1989 & BRASIL & 31,67 & ITÁLIA & 89,95 & JAPÃO & 151 & 31,67 \\
\hline \multicolumn{9}{|l|}{ INDÚSTRIA } \\
\hline & 1979 & $\begin{array}{l}\text { CHILE } \\
\text { EUA }\end{array}$ & 11,63 & URUGUAI & 36,21 & ARGENTINA & 66,2 & 21,24 \\
\hline & 1980 & EUA & 12,89 & PORTUGAL & 47,69 & ARGENTINA & 77,56 & 23,56 \\
\hline & 1981 & EUA & 17,74 & PORTUGAL & 46,93 & REINO UNIDO & 68,08 & 30,72 \\
\hline & 1982 & MÉXICO & 22,03 & BÉLGICA & 50,99 & IRLANDA & 75,74 & 36,36 \\
\hline & 1983 & MÉXICO & 14,32 & ESPANHA & 46,37 & GHANA & 75,27 & 25,86 \\
\hline & 1984 & SUÉCLA & 22,96 & GHANA & 45,52 & JAPÃO & 81,11 & 24,91 \\
\hline & 1985 & BRASIL & 18,83 & AUSTRÁLLA & 42,33 & JAPÃO & 74,56 & 18,83 \\
\hline & 1986 & SUÉCLA & 26,94 & ISRAEL & 50,18 & JAPÃO & 89,9 & 28,41 \\
\hline & 1987 & ARGENTINA & 32 & ISRAEL & 57,23 & JAPÃO & 105,45 & 46,92 \\
\hline & 1988 & CANADÁ & 25,07 & ITÁLIA & 63,59 & JAPÃO & 116 & 41 \\
\hline & 1989 & ARGENTINA & 34,05 & IRLANDA & 60,26 & JAPÃO & 100 & 41,99 \\
\hline
\end{tabular}

Fonte: ELETROBRAS

Notas: (a) para a classe RESIDENCLAL foi considerado um consumo mensal de $200 \mathrm{kWh}$

(b) para a classe INIDUSTRLAL foi considerada uma demanda de I MW e um fator de carga de $60 \%$

(c) as tarifas da ALLEMANHA correspondem a Alemanha Federal 
TABELA 5

REQUISITOS E OFERTAS (MW ano)

\begin{tabular}{|c|c|c|c|c|c|c|}
\hline \multirow[b]{2}{*}{ ANO } & \multicolumn{2}{|c|}{ MERCADO } & \multicolumn{2}{|c|}{ OFERTA } & \multicolumn{2}{|c|}{ SOBRA } \\
\hline & SUL & SUDESTE & SUL & $\overline{\text { SUDESTE }}$ & SUL & SUDESTE \\
\hline--- & $-\ldots$ & (5) & -.-- & - & --. & - \\
\hline 1985 & 2827 & 13233 & 3965 & 13029 & 457 & 477 \\
\hline 1986 & 3088 & 14128 & 4133 & 13985 & 535 & 368 \\
\hline 1987 & 3445 & 16052 & 3988 & 15924 & 39 & 377 \\
\hline 1988 & 3604 & 16609 & 4126 & 16569 & 286 & 192 \\
\hline 1989 & 3784 & 17300 & 4325 & 17524 & 160 & 617 \\
\hline 1990 & 3901 & 17673 & 4503 & 18997 & 369 & 1557 \\
\hline 1991 & 4274 & 18702 & 4661 & 19919 & 304 & 1300 \\
\hline 1992 & 4311 & 18093 & 4843 & 19425 & 371 & 1493 \\
\hline
\end{tabular}

Fonte: $\quad$ GCOI - Grupo Coordenador Para a Operação Interligada 
Tabelat 6

PREVISAO DO MERCADO DE ENERGIA ELETRTCA

CRESCIMENTO OOI PIB E ELASTICIDADE

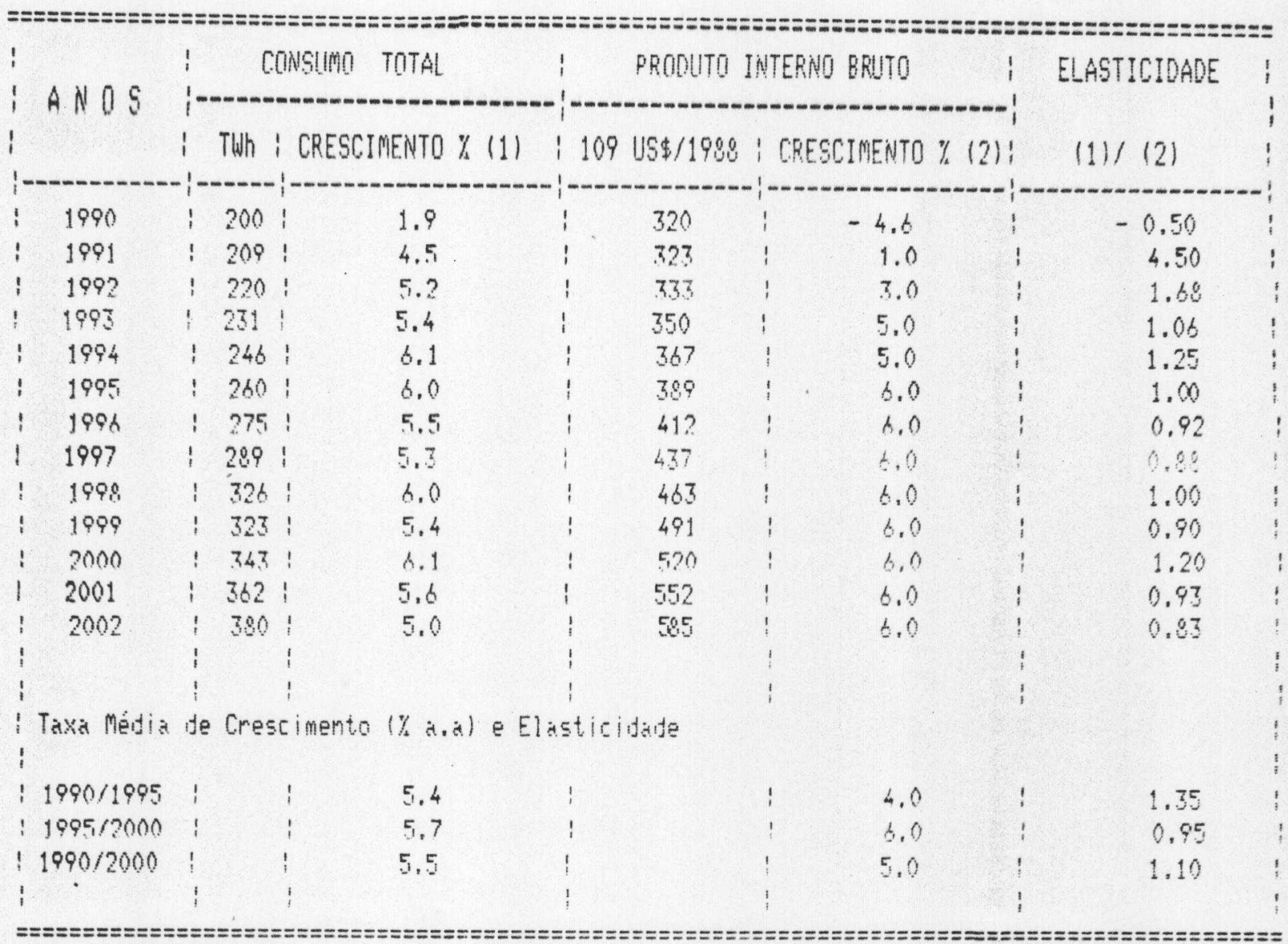

FONTE: GCPS - CICLO/92 


\author{
Tabela 7 \\ PROJECOES DE DEMANDA PARA D ANO 1990
}

- Sistema interligado SUDFGTE/CFNTRO OFSTE/SUL -

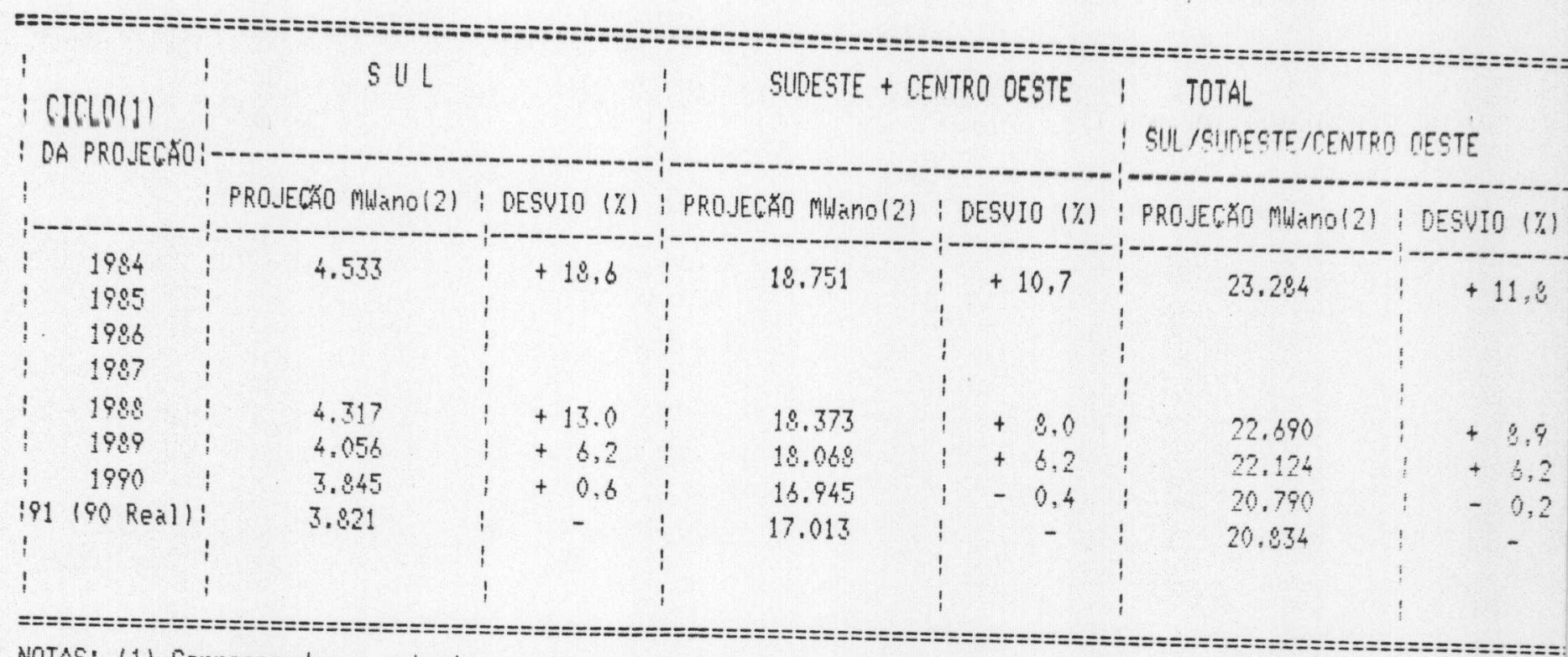

NOTAS: (1) Compesoonde aO primeimo ano do horizonte de dez anos compóem a projecto

(2) Cormesponde o Consumo Total. inclusive Eletrotermia

Fonte: GCPS - Grupo Coordenador Para O Planejamento do Sistema 
TABELA 8

\section{CONSUMO DE ENERGIA ELÉTRICA NO ESTADO DE SÃO PAULO}

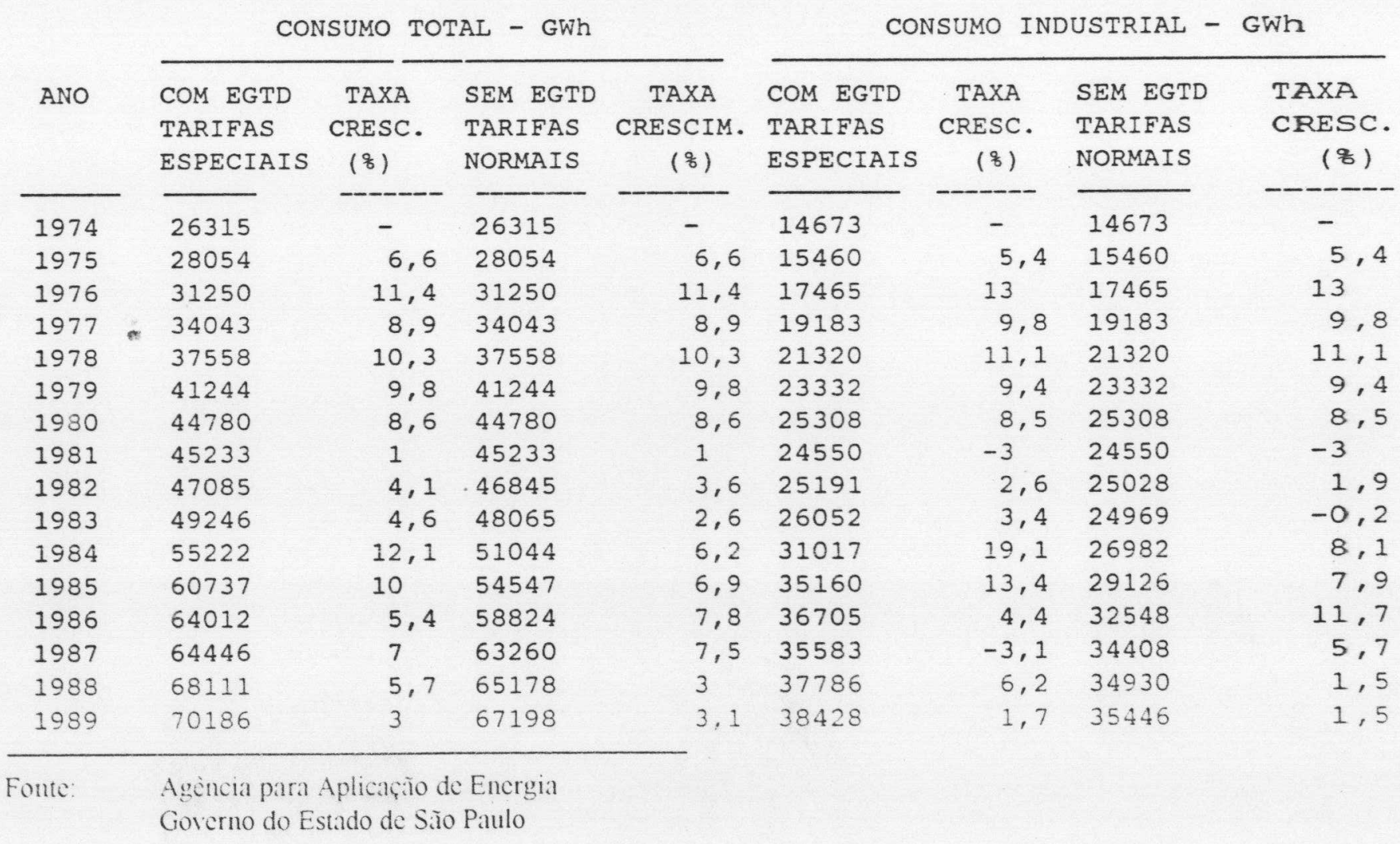




\author{
TABELA 9
}

\title{
REGRESSÕES DAS SÉRIES DE CONSUMO, PIB E PREÇO DA ENERGIA
}

\section{CLASSE INDUSTRIAL NO ESTADO DE SÃO PAULO - 1974 A 1989}

\begin{tabular}{|c|c|c|}
\hline & COM EGTD & SEM EGTD \\
\hline Constante & 1,069588 & 0,589299 \\
\hline Desvio Padrão de $Y$ & 0,050673 & 0,016758 \\
\hline R2 & 0,975405 & 0,996018 \\
\hline NN. de Observações & 14 & 14 \\
\hline Graus de Liberdade & 9 & 9 \\
\hline \multicolumn{3}{|c|}{ Variáveis Explicativas } \\
\hline PIB do Ano & - & \\
\hline Coeficiente & 0,217862 & 0,518531 \\
\hline Desvio Padrão & 0,288951 & 0,090875 \\
\hline$t$ de Student & 0,753977 & 5,705974 \\
\hline \multicolumn{3}{|c|}{ Razão (PIB do ano/PIB ano anterior) } \\
\hline Coeficiente & $-0,67042$ & $-0,31616$ \\
\hline Desvio Padrão & 0,260137 & 0,132131 \\
\hline$t$ de Student & $-2,57719$ & $-2,39281$ \\
\hline \multicolumn{3}{|c|}{ Consumo do Ano Anterior } \\
\hline Coeficiente & 1,057001 & 0,89023 \\
\hline Desvio Padrão & 0,093863 & 0,044824 \\
\hline$t$ de student & 11,26106 & 19,92282 \\
\hline \multicolumn{3}{|c|}{ Preço Médio da Energia Elétrica } \\
\hline Coeficiente & 0,025223 & $-0,06389$ \\
\hline Desvio Padrão & 0,067187 & 0,031369 \\
\hline t de student & 0,375422 & $-2,037$ \\
\hline
\end{tabular}

Nota: $t$ de Student tabelado $(5 \%, 9$ graus de liberdade $)=2.262$

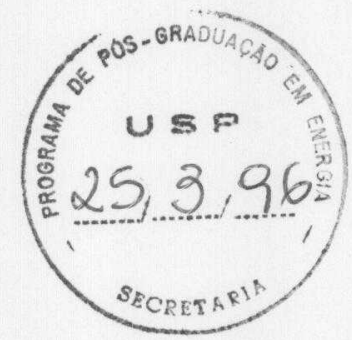


Tabela 10

CONDTCHES DE ATENDIMENTO - CTCLO 92

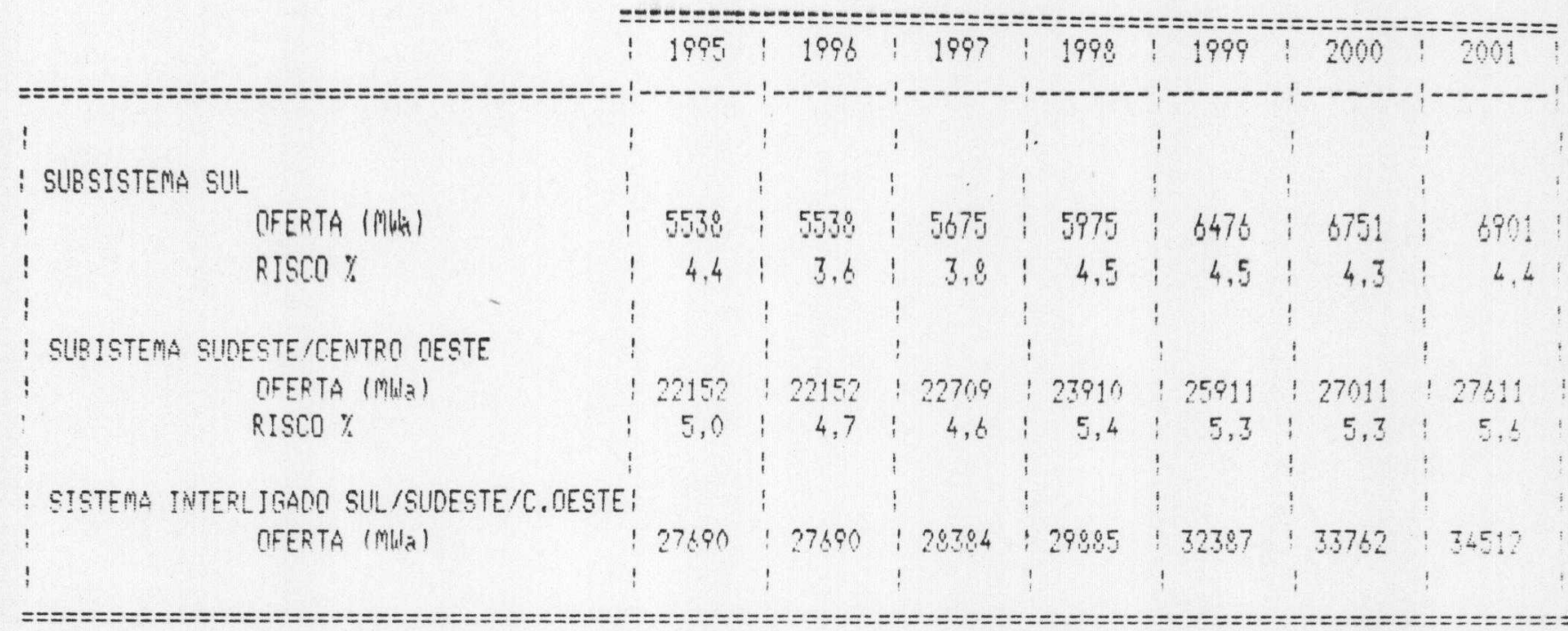

FONTE: CTEE/GCPS 
TABELA $\$ 1$

\section{SIMULAÇÃO DO SISTEMA SEM REDUÇÃO DO MERCADO CONJUNTO DE OBRAS E DATAS DE ENTRADAS EM OPERAÇÃO}

\begin{tabular}{|c|c|c|}
\hline USINA & EMPRESA & INICIO OPERAÇÃO \\
\hline JAGUARA & CEMIG & DEZ/96 \\
\hline DONA FRANCISCA & CEEE & $\mathrm{DEZ} / 96$ \\
\hline SANTA BRANCA & LIGHT & $\mathrm{MAR} / 97$ \\
\hline PAULÕNIA I & CESP & $\mathrm{DEZ} / 97$ \\
\hline CANDIOTA III - 1 & CEEE & $\mathrm{DEZ} / 97$ \\
\hline MANSO & ELETRONORTE & $\mathrm{DEZ} / 97$ \\
\hline IGARAPAVA & CEMIG & $\mathrm{MAR} / 98$ \\
\hline CORUMBÔ I & FURNAS & $\mathrm{ABR} / 98$ \\
\hline PAULÕNIA II & CESP & JUN / 98 \\
\hline ITA & ELETROSUL & JUN / 98 \\
\hline S.JOSE DOS CAMPOS & CESP & $\mathrm{DEZ} / 98$ \\
\hline SANTA RITA & CEMIG & $\mathrm{MAR} / 99$ \\
\hline COUTO MAGALHÃES & ELETRONORTE & MAR/99 \\
\hline QUEIMADO & CEMIG & MAR/99 \\
\hline SALTO CAXIAS & COPEL & SET/98 \\
\hline CANA BRAVA & FURNAS & $\mathrm{SET} / 99$ \\
\hline FORMOSO & CEMIG & $\mathrm{SET} / 99$ \\
\hline SIMPLÕCIO & FURNAS & OUT/99 \\
\hline IGARAPE II & CEMIG & $\mathrm{DEZ} / 99$ \\
\hline GARABI - 50\% & ELETROSUL & $\mathrm{MAR} / 2000$ \\
\hline CARVÃO $1-50 \mathrm{MW} 1 / 4$ & ELETROSUL & DEZ/99 \\
\hline BOCAINA & CEMIG & $\mathrm{MAR} / 2000$ \\
\hline PICADA & CEMIG & MAR/ 2000 \\
\hline ROSAL & CERJ & $\mathrm{MAR} / 2000$ \\
\hline CAMPOS NOVOS & ELETROSUL & MAR / 2000 \\
\hline CAPIM BRANCO & CEMIG & JUN / 2000 \\
\hline IRAPE & CEMIG & JUN / 2000 \\
\hline MAUA & COPEL & MAR/ 2000 \\
\hline CEBOLÃO & COPEL & $\mathrm{SET} / 2000$ \\
\hline FRANCA AMARAL & CERJ & $\mathrm{SET} / 2000$ \\
\hline SAPUCAIA/ANTA & FURNAS & $\mathrm{DEZ} / 2001$ \\
\hline CADIOTA III-2 & CEEE & $\mathrm{DEZ} / 2000$ \\
\hline CARVÃO $2-50$ MW $2 / 4$ & ELETROSUL & $\mathrm{DEZ} / 2000$ \\
\hline CARVÃO 3-50 MW $3 / 4$ & ELETROSUL & $\mathrm{DEZ} / 2000$ \\
\hline MANHAÇU & CEMIG & MAR/2001 \\
\hline QUARTEL & CEMIG & MAR/ 2001 \\
\hline TELEMACO BORBA & COPEL & $M A R / 2001$ \\
\hline ITAOCARA & FURNAS & $\mathrm{MAR} / 2001$ \\
\hline JATAIZINHO & COPEL & MAR/2001 \\
\hline SERRA DO FACÃO & FURNAS & MAR/ 2001 \\
\hline CANOAS I & CESP & $\mathrm{MAR} / 2001$ \\
\hline BARRA GRANDE & ELETROSUL & SET/ 2001 \\
\hline FUNIL GRANDE & CEMIG & $\mathrm{SET} / 2001$ \\
\hline SOBRA & CEMIG & SET/ 2001 \\
\hline MACHADINHO & ELETROSUL & $\mathrm{MAR} / 2001$ \\
\hline BARRA DO PEIXE & ELETRONORTE & $\mathrm{MAR} / 2001$ \\
\hline FOZ DO BEZERRA & FURNAS & SET/2001 \\
\hline MONJOLINHO & ELETROSUL & $\mathrm{SET} / 2001$ \\
\hline
\end{tabular}


Tabela 12

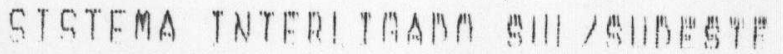

COMPARATIUO DAS PREUTSOES PARA O ANO 1992

CTC10 $1995 \times$ CTCIO 199?
\end{abstract}

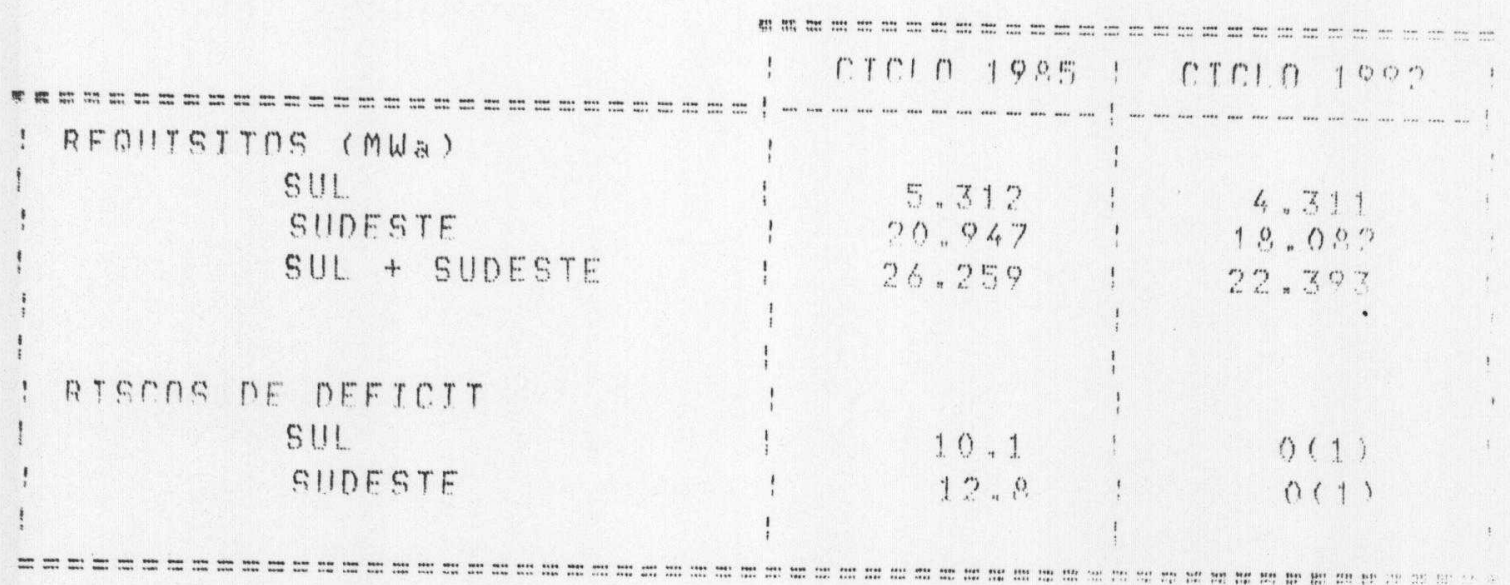

Fonte: Grupo Coordenador para o Planejamento do sistema GCPS

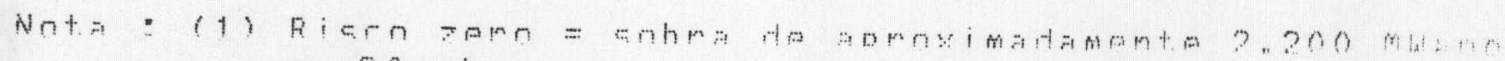
na 0 ferta 
Tabela 13

INFLACAO E PJB - $1980-1990$

PRODUTO IKTERNO BRUTD - PIB

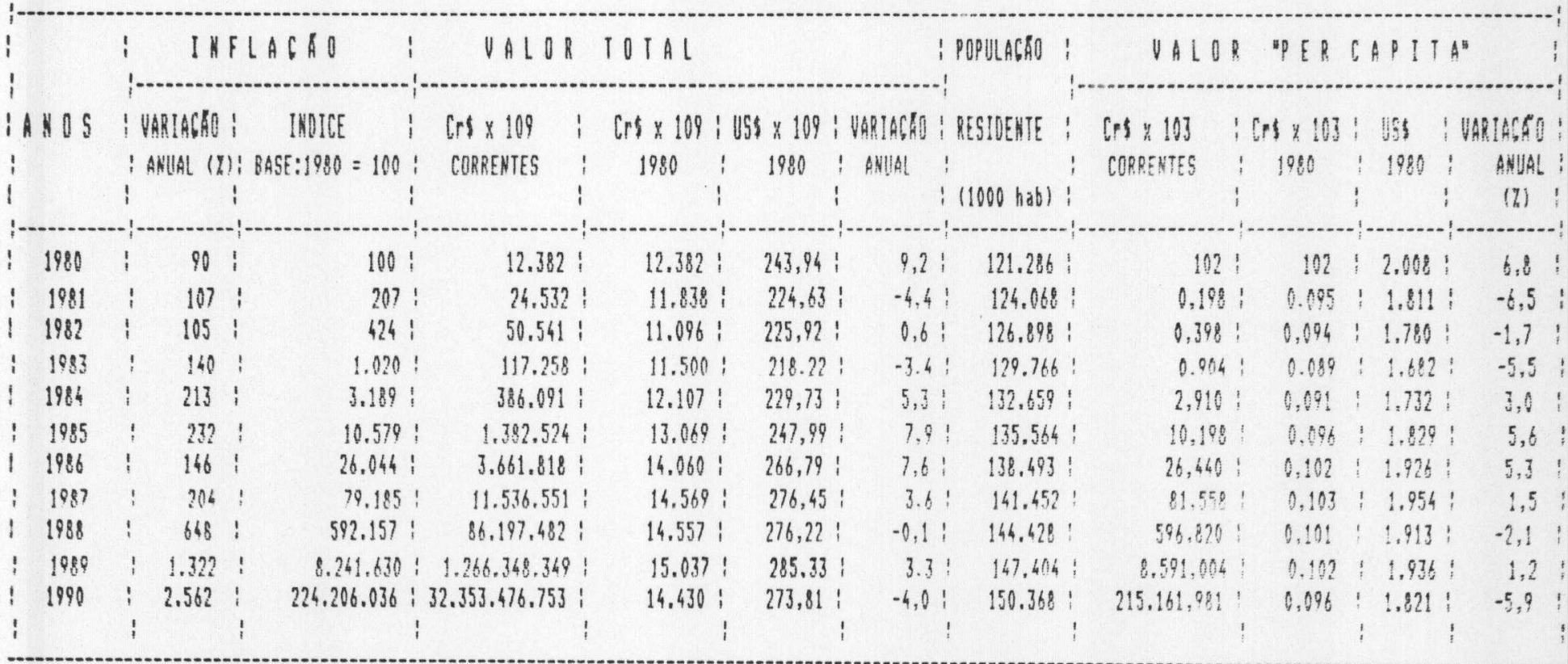

Fonte: Fundacro Instituto Brasileiro de Geografia e Estatística - IBGE

Diretomia de Pesouisas - Deoartamento de Contas Nacionais

Industrial 
Tabel त 14

SISTEMA INTERLIGADO SUL/SUOESTE

COMPARATIUO ENTRE CRONOGRAMAS DE ENTRADA EM OPERACZOA EM 1992

CICLO $1995 \times$ CICLO 1992

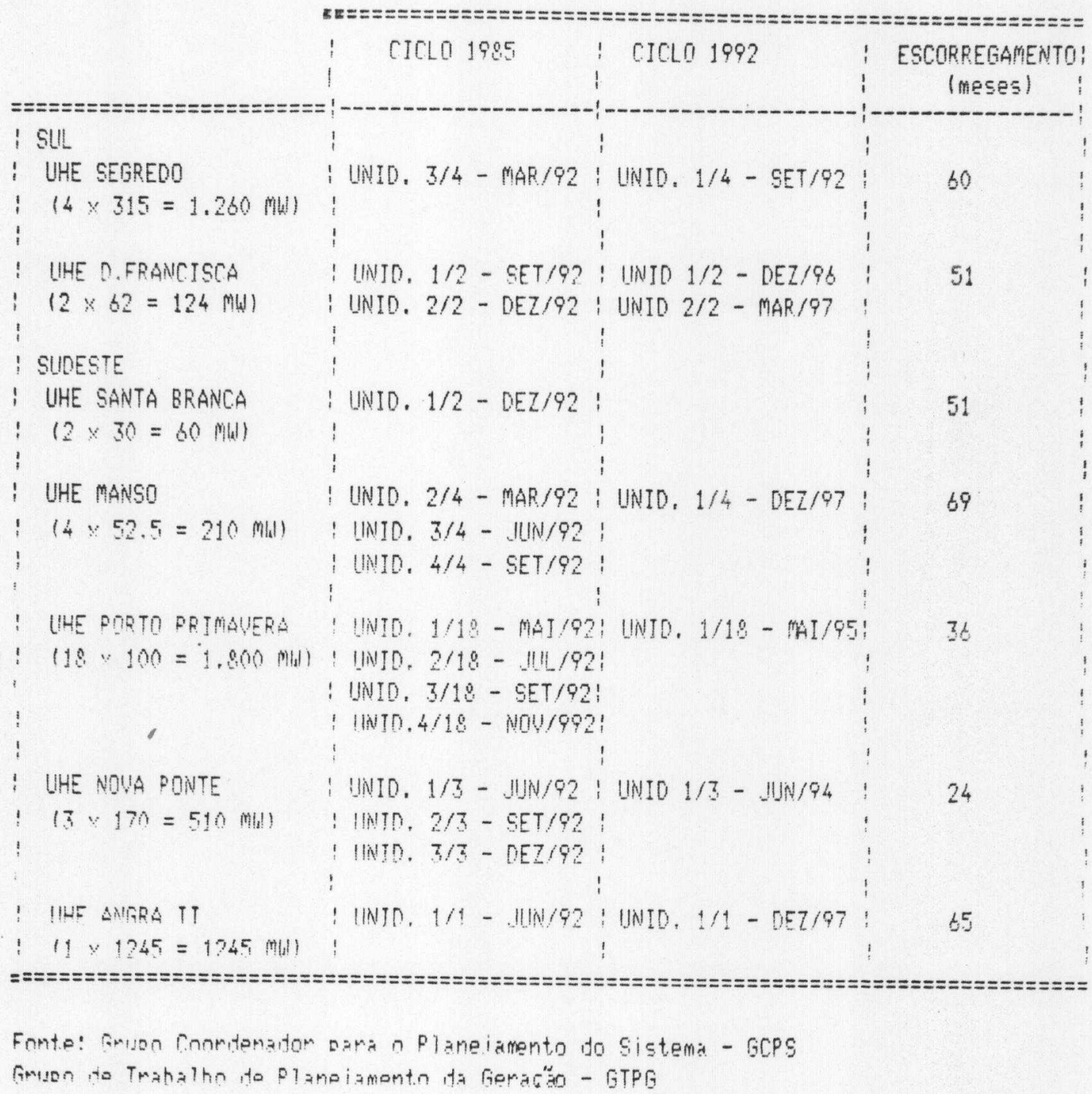


Tabel a

CRESCTMENT DE CUSTOS EM PROSETOS HTDRELETRTCOS

DTSTRTBUTCĂO PERCENTUAL DAS VARIACOES VERTFTCADAS

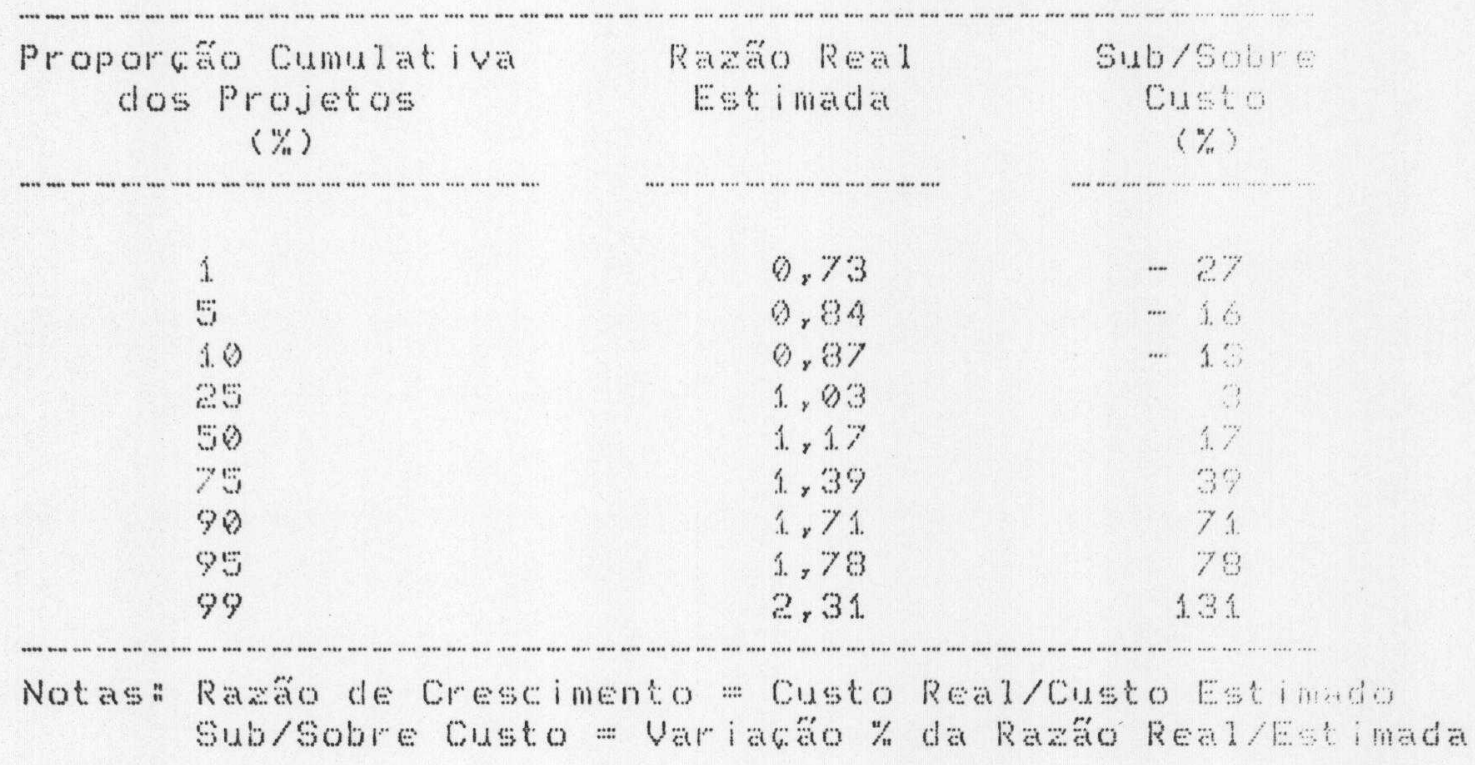


TABELA 16

DISTRIBUICC̃̃O POR FAIXAS DE CRESCIMENTO - PROJ. HIDROELÉTRICOS

FAIXAS DE CRESCIMENTO

\begin{tabular}{|c|c|c|c|c|}
\hline$<0.75$ & $0.75-0.99$ & $1.00-1.25$ & $1.25-1.50$ & $>1.50$ \\
\hline 2 & 18 & 47 & 16 & 15 \\
\hline
\end{tabular}


Tabela 17

- Projecóes de Mercado (GWh) -

\begin{tabular}{|c|c|c|c|c|}
\hline ANO & $1988 / 1997$ & $1989 / 1998$ & $1990 / 1999$ & $1991 / 2000 !$ \\
\hline $1-\cdots$ & & 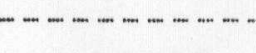 & 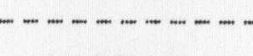 & - \\
\hline$n$ & 174744 & 181709 & 188369 & 155034 \\
\hline$n+1$ & 186667 & 193806 & 198237 & 163978 \\
\hline$n+2$ & 198764 & 206946 & 208613 & 173019 \\
\hline$n+3$ & 211615 & 218600 & 220790 & 181665 \\
\hline$n+4$ & 238675 & 233454 & 232888 & 190425 \\
\hline$n+5$ & 238675 & 246944 & 246000 & 199684 \\
\hline$n+6$ & 252586 & 260628 & 259874 & 212440 \\
\hline$n+7$ & 268695 & 273540 & 274170 & 223200 \\
\hline$n+8$ & 282387 & 288633 & 288326 & 235118 \\
\hline$n+9$ & 298418 & 303333 & 302447 & $24660 \%$ \\
\hline$\%$ ano & 6.13 & 5.95 & 5.40 & 5.26 \\
\hline
\end{tabular}

Fonte: Gmoo Coomdenadom para o Plameiamento do sistemeGCPS 
Tabela 18

-.- Imvestimentos (US* * 10E6) -

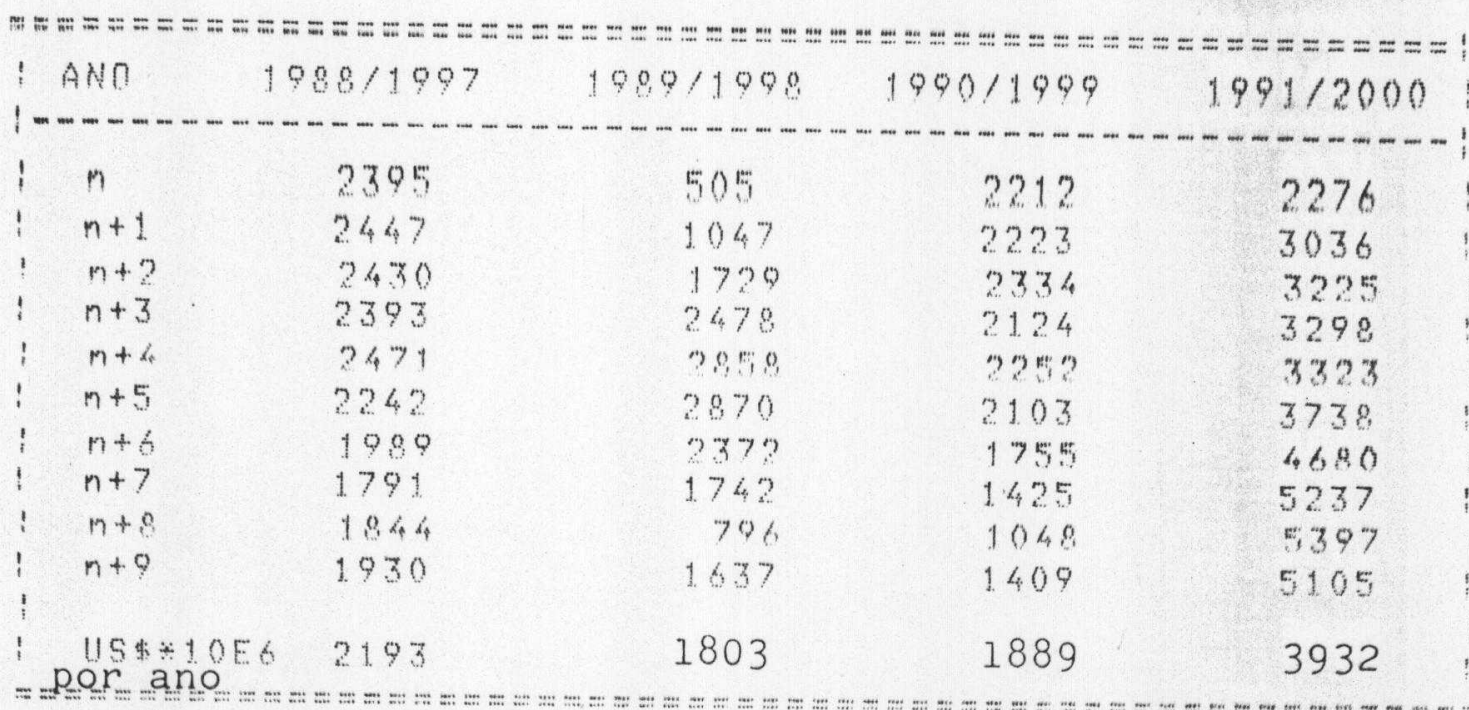

Fonte: Grupo Coordenador para planejamento do sietona GCPS 
Tabed a 1 ...?

\section{TARIFAS MÉDIAS DE SULRIMENTO \\ - CESP}

US5/MWh

\begin{tabular}{|c|c|c|c|c|}
\hline IANO & TCMg(1) & TAJUSTADA (2) & TLEGAL(3) & TREAL (4) \\
\hline 1990 & $\cdots$ & 54.88 & 40.46 & 32.63 \\
\hline : 1981 & $\ldots$ & 60,27 & 47.60 & 43.64 \\
\hline$: 1982$ & $\cdots$ & 68.69 & 48.28 & 40.63 \\
\hline 1.983 & $\ldots$ & $\because 0.80$ & 36.41 & 20,64 \\
\hline $1 \quad 1984$ & 63.93 & $44, \cdots$ & 29.67 & $26 \cdot 34$ \\
\hline 1985 & 63.93 & 43.51 & 29.57 & $24 \times 25$ \\
\hline 1986 & 63.93 & 32.79 & 33.46 & 27.61 \\
\hline$: 1987$ & 63.93 & 62.43 & 40.00 & 36.55 \\
\hline 1998 & 63.93 & 58 . 1.3 & 41.91 & $4 \mathrm{~L} .61$ \\
\hline 1989 & 82.93 & 63.14 & 00.92 & 40,25 \\
\hline 11.990 & 1.0 .91 & 73.91 & 52.57 & 50.76 \\
\hline 1991 & & & & \\
\hline
\end{tabular}

(1) TCMO -.. rarifa baseada nos custos marginais

(2) TAJUSTADA -.. Tar ifa baseada nos custos medios dos at vos historicos, entretantor com essess at duat 1 a a dos pelo Tlop

(3) TLEGALADA … Tarifa basenda nos custos medios dos at ivos historicosy entretantor com esstes

(4) TREAL... at lua 1 i zados pelo BTN

.... Tar ifa Real Ver ificada

Fontes" Divisáo de Estudos Economicos - FTE/FT/CESP,

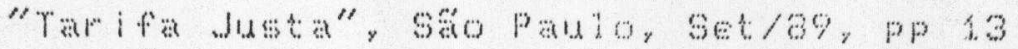

Divisäo de Estudos rarifarios -...TT/FT/CEsF, Tarifa de Referencia a Custos Marginats 1980 a $1990^{\prime \prime}$. 580 Paudo, Mai/89. 
Tabel 20

GERAÇÃO INTERNA DE RECURSOS (GIR) x INVESTIMENTOS PROGRAMADOS

- CESP --

\begin{tabular}{|c|c|c|c|c|}
\hline & GIR & GIR & GIR & GIR \\
\hline ANI & $\frac{\text { NECESSÁRIA }}{\text { INVESTIMENTOSOS }}$ & $\begin{array}{c}\text { AJUSTADA } \\
\text { INUESTTMENTOS }\end{array}$ & $\begin{array}{c}\text { LEGAL } \\
\text { INVENTIMENTOS }\end{array}$ & REAL \\
\hline
\end{tabular}

1. .26

1. 51

1. 28

1.04

0.98

0. 91

0.41

1.00

1. 34

1.05

0.0 .1

0.90

0.0 .0

0.68

FINTE: CESP

Divisão de Gestão Tarifária 
Tabela 21

-.. Potencial de Reducto do Consuno

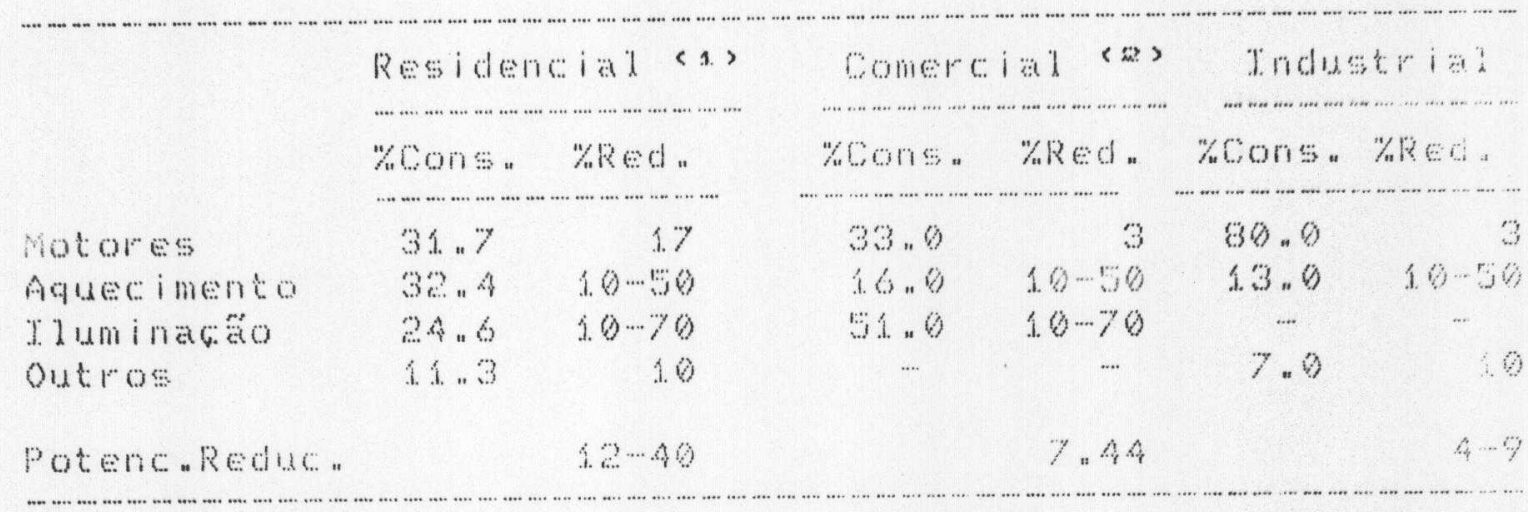

Fonte: Howard s. Oedder, The Potential for Elefericits Conservation in Brasil

Notas: (1) Tnchui aquecimento d'agua fe foros de passar roupas

(2) Tnclui Ar Condicionado 
Tabela 22

Oferta e Risco de Déficit

\begin{tabular}{|c|c|c|c|c|c|}
\hline \multirow{3}{*}{ ANO } & \multicolumn{4}{|c|}{ SUBSISTEMAS } & \multirow{3}{*}{$\begin{array}{c}\text { SISTEMA } \\
\text { INTERLIGADO } \\
\begin{array}{c}\text { Oferta } \\
\text { (MWano) }\end{array} \\
\end{array}$} \\
\hline & \multicolumn{2}{|c|}{ SUL } & \multicolumn{2}{|c|}{ SUDESTE } & \\
\hline & $\begin{array}{c}\text { Oferta } \\
\text { (MWano) }\end{array}$ & $\begin{array}{c}\text { Risco } \\
\%\end{array}$ & $\begin{array}{c}\text { Oferta } \\
\text { (MWano) }\end{array}$ & $\begin{array}{c}\text { Risco } \\
\%\end{array}$ & \\
\hline 1994 & 5538 & 4.2 & 22152 & 5.3 & 27690 \\
\hline 1995 & 5538 & 4.4 & 22152 & 5.0 & 27690 \\
\hline 1996 & 5538 & 3.6 & 22152 & 4.7 & 27690 \\
\hline 1997 & 5675 & 3.8 & 22709 & 4.6 & 28384 \\
\hline 1998 & 5975 & 4.5 & 23910 & 5.4 & 29885 \\
\hline 1999 & 6476 & 4.5 & 25911 & 5.3 & 32387 \\
\hline 2000 & 6751 & 4.3 & 27011 & 5.3 & 33762 \\
\hline 2001 & 6901 & 4.4 & 27611 & 5.6 & 34512 \\
\hline 2002 & 7265 & 2.5 & 29072 & 4.8 & 36337 \\
\hline 2003 & 7265 & 3.0 & 29072 & 5.3 & 36337 \\
\hline
\end{tabular}

Fonte: CTEE-GCPS - Simulação preliminar para o Plano Decenal de Expansão 1992-2001 Custo Marginal de Expansão (C1): US\$ 46,58/MWh

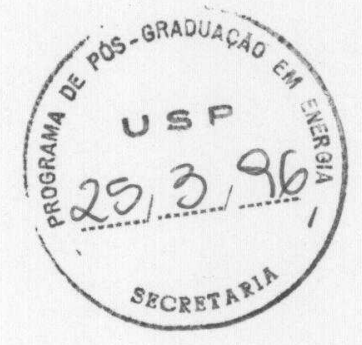


TABELA 23

SISTEAA IHTERLIGADO SUL/SUDESTE

CALCULO DO CUSTO MaRGiKaL OE EXPaASAO

custos equivalentes aiUaldzados e custo marginal de expansao

(a)

USS $1.00=$ CRS 155,375 (0E $2 / 901$

INUESTINENTO ANUAL(CATE - $10 \ldots 2$ US\$/ano)

1405.97

OFERTA DE ENERGIA (ICEO - MWano)

4225.29

OFERTA DAS NUCLEARES (EN - MWano)

464.08

CUSTO GERACAO TERMICA (CGTE - 10HÉ USS/anO)

125.24

CUSTO DEFICIT ESPERADO (CDFE - 10ะE US\$/anO)

$-36.76$

operacao e manUtencaO (COHE - $107 \pm 6$ USS/ano)

56.00

IKUESTIHEHTO POTENCIA COAPEDPEO - 10E $\$ 6$ US\$/anO

0.00

CUSTO DO DEFICIT (CIDE - USS/BWh)

480.00

CUSTO MARGIYAL DE OPERACAO (CHO - USS/AWH)
CUSTO AARGIHAL DE EXPAMSAO (CAE - USS/AUH)

relaca che / ChO
46.58

1.19

Fonte: GCPS (siaulacao preliainar do ciclo 1992) 
S!ST:Ah IWERLIGADO SUL/SUDSETE

IMELLA 2

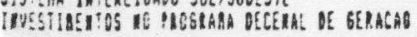

uss $: .00=$ ans $155,375 \cos 2 / 901$

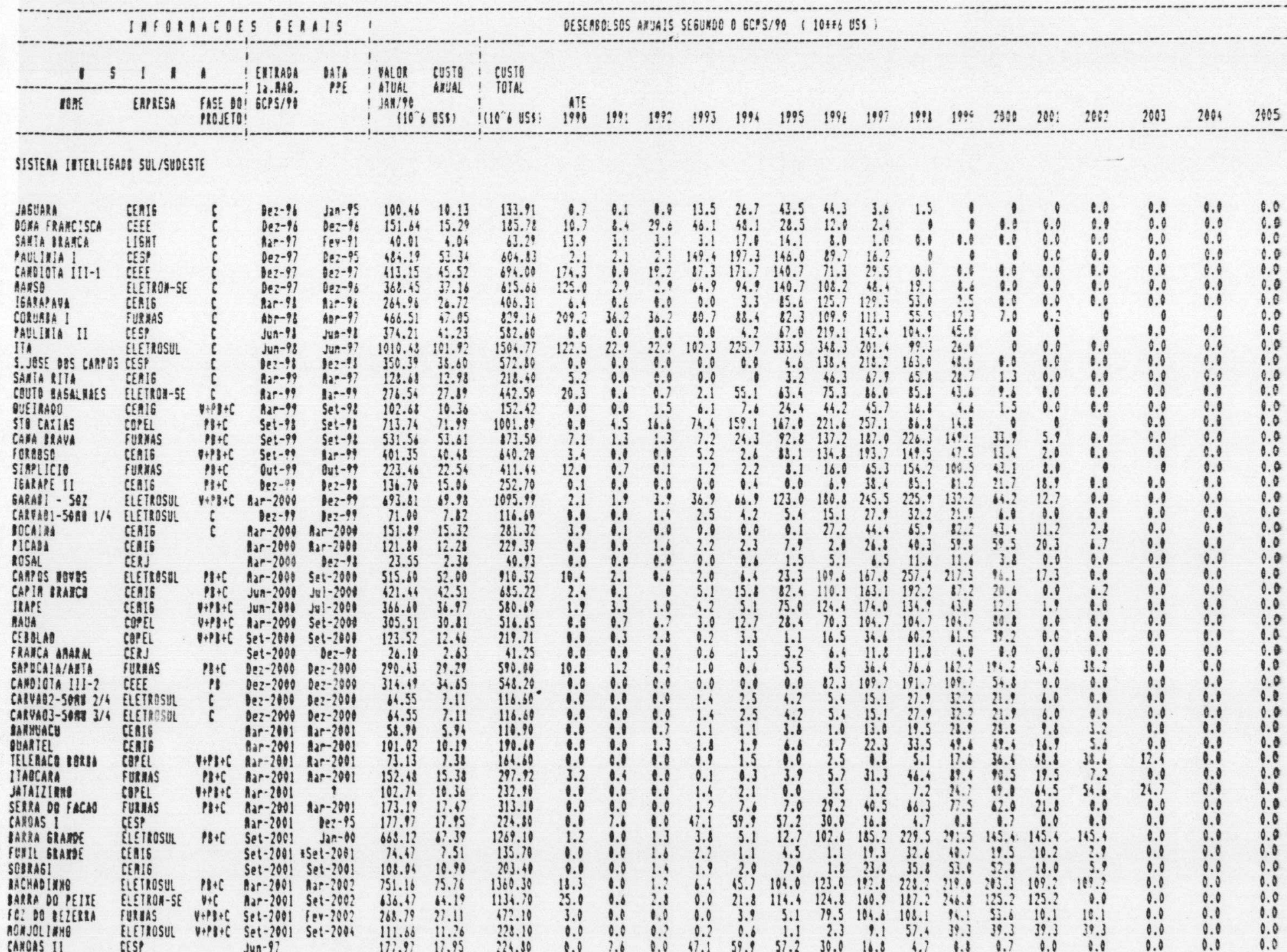

Cise $213330.1 !$

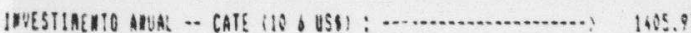


TABELL 25

SISIEAA INIERLIGADO SUL./SUDESTE

CALCULO DO CUSTO ANUAL OE OPERACAO E AaNUTERCAO (COHE) E ACRESCIHO OE POHTA

USS $1.00=$ CRS 155,375 (DEL/190)

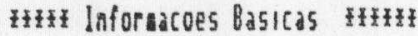

- constantes da curva de custo anual oe operacad e manutencao:

$\begin{array}{lll}\text { curva 1: } & 114.93 & \text { curva } 2: \\ j= & c=10.57 . \\ b= & -0.6064 & d=-0.1281\end{array}$

PONTO DE CORTE HA CURUA PE - RU)

146.71

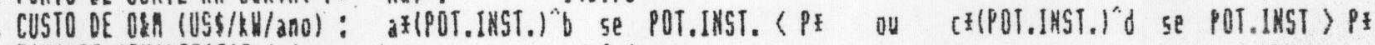

- iaXa de AIUALIZACAO $(\mathrm{i}-\mathrm{PU})$ :

0.1

\begin{tabular}{|c|c|c|c|c|c|c|c|c|c|c|c|}
\hline \multirow{3}{*}{$\begin{array}{c}\text { U S I K A } \\
\text { IOAE }\end{array}$} & \multirow{3}{*}{ POT.INST. } & ! & $!$ & 1 & \multicolumn{6}{|c|}{ ACRESCIIHO OE POTENCIA ANUAL (OPK-ANE) } & \multirow[b]{3}{*}{2003} \\
\hline & & $\begin{array}{l}\text { custo } \\
\text { O\&H }\end{array}$ & $\begin{array}{l}\text { V.AIUAL } \\
\text { JAN/92 }\end{array}$ & $\begin{array}{l}\text { U.ATUALL } \\
\text { JAN/92 }\end{array}$ & & & & & & & \\
\hline & & USS/KV/ano & $!\left(10^{\circ} 6058\right)$ & i (AVI) & 1997 & 1998 & 1999 & 2000 & 2001 & 2002 & \\
\hline JAGUARA & $616 !$ & 6.64 & 0.62 & 134 & 216 & j & 0 & 0 & 0 & 0 & 0 \\
\hline OONA FRAICISCA & 125 ! & 6.15 & 0.48 & 78 & 125 & 0 & 0 & 0 & 0 & 0 & 0 \\
\hline SAMTA BRAMCA & $49 !$ & 10.85 & 0.33 & 30 & 49 & 0 & 0 & 0 & 0 & 0 & 0 \\
\hline PAULIKIA I & $350 !$ & 21.50 & 4.67 & 217 & 350 & 0 & 0 & 0 & 0 & 0 & 0 \\
\hline CAMDIOTA III-1 & $350 !$ & 25.30 & 5.00 & 198 & 0 & 350 & 0 & 0 & 0 & 0 & 0 \\
\hline MAKSO & $210 !$ & 5.33 & 0.62 & 116 & 0 & 158 & 53 & 0 & 0 & 0 & 0 \\
\hline IGARAPAVA & $210 !$ & 5.33 & 0.61 & 114 & 0 & 126 & 84 & $\theta$ & 0 & 0 & 9 \\
\hline CORUABA I & $375 !$ & 4.95 & 1.02 & 205 & 0 & 250 & 125 & 0 & 0 & 0 & 0 \\
\hline PAULIHIA II & $350 !$ & 21.50 & 4.25 & 198 & 0 & 350 & 0 & 0 & 0 & 0 & 0 \\
\hline IIA & $1620 !$ & 4.10 & 3.52 & 859 & 0 & 540 & 1080 & 0 & 0 & 0 & 0 \\
\hline S.JOSE DOS CAMPOS & $350 !$ & 21.50 & 3.86 & 180 & 0 & 0 & 350 & 0 & 0 & 0 & 0 \\
\hline SANTA RITA & $75 !$ & 8.38 & 0.32 & 38 & ? & 0 & 75 & $?$ & 0 & 0 & 0 \\
\hline COUTO AAGALHAES & $220 !$ & 5.30 & 0.58 & 110 & 0 & 0 & 165 & Sis & 0 & 0 & 0 \\
\hline DUEIAADO & $100 !$ & 7.04 & 0.36 & 51 & 0 & 0 & 100 & 0 & 0 & 0 & 0 \\
\hline STO CAXIAS & $1000 !$ & 4.36 & 2.30 & 526 & 0 & 250 & 750 & 0 & 0 & 0 & 0 \\
\hline CAHA BRAVA & $450 !$ & 4.83 & 1.04 & 216 & 0 & 0 & 113 & 338 & 0 & 0 & 0 \\
\hline FORPOSO & $300 !$ & 5.09 & 0.74 & 145 & 0 & 0 & 100 & 200 & 0 & 0 & 0 \\
\hline SIAPLICIO & $180 !$ & 5.44 & 0.47 & :7 & 0 & 0 & 60 & 120 & 0 & 0 & 0 \\
\hline IGARAPE II & $125 !$ & 21.50 & 1.25 & 58 & 0 & 0 & 0 & 125 & 0 & 0 & 0 \\
\hline GARABI - 50\% & $900 !$ & 4.42 & 1.77 & 401 & 0 & 0 & 0 & 450 & 450 & 0 & ? \\
\hline CARVAO1-50AY $1 / 4$ & $50 !$ & 25.30 & 0.59 & 23 & 0 & 0 & 0 & 50 & 0 & 0 & 0 \\
\hline BOCAINA & $150 !$ & 5.56 & 0.39 & 70 & ! & 0 & ! & 150 & 0 & ? & 0 \\
\hline PICADA & $100 !$ & 7.04 & 0.33 & 47 & 0 & 0 & 0 & 100 & 0 & 0 & 0 \\
\hline ROSAL & $58 !$ & 9.80 & 0.27 & 27 & 0 & 0 & 0 & 58 & 0 & 0 & 0 \\
\hline CAAPOS NOUOS & $880 !$ & 4.44 & 1.78 & 401 & 0 & 0 & 0 & 660 & 220 & 0 & 0 \\
\hline CAPIA BRAKCO & $600 !$ & 4.66 & 1.26 & 271 & 0 & 0 & $?$ & 400 & 200 & 0 & 0 \\
\hline IRAPE & $420 !$ & 4.86 & 0.93 & 190 & 0 & 0 & 0 & 280 & 140 & 0 & 0 \\
\hline HAUA & $472 !$ & 4.80 & 1.06 & 220 & 0 & 0 & 0 & 472 & 0 & 0 & ? \\
\hline CEBOLAO & $194 !$ & 5.38 & 0.47 & 86 & 0 & 0 & 0 & 97 & 97 & 0 & 0 \\
\hline FRAMCA AGARAL & $32 !$ & 14.05 & 0.20 & 14 & 0 & 0 & 0 & 16 & 16 & 0 & 0 \\
\hline SAPUCAIA/AKTA & $316 !$ & 5.06 & 0.68 & 134 & 0 & 0 & 0 & 0 & 316 & 0 & 0 \\
\hline CAMDIOIA III-2 & $350 !$ & 25.3 & 3.76 & 148 & 0 & 0 & 0 & 0 & 350 & 0 & 0 \\
\hline CARUA02-5OAN $2 / 4$ & So! & 25.3 & 0.54 & 21 & 0 & 0 & 0 & 0 & 50 & 0 & 0 \\
\hline CARVAO3-50月V $3 / 4$ & $50 !$ & 25.3 & 0.54 & 21 & $?$ & $?$ & 0 & 0 & 50 & 0 & 0 \\
\hline BAHHUACU & $110 !$ & 6.65 & 0.31 & 47 & 0 & 0 & 0 & 0 & 110 & 0 & 0 \\
\hline QUARIEL & $100 !$ & 7.04 & 0.30 & 42 & 0 & 0 & 0 & 0 & 100 & 0 & 0 \\
\hline TELERACO BORBA & $128 !$ & 6.06 & 0.33 & 54 & 0 & 0 & 0 & 0 & 128 & 0 & 0 \\
\hline IIAOCARA & $210 !$ & 5.33 & 0.47 & 89 & ! & 0 & 0 & 0 & 210 & 0 & 0 \\
\hline JATAIZINHO & $192 !$ & 5.39 & 0.14 & 81 & 0 & 0 & 0 & 0 & 192 & 0 & 0 \\
\hline SERRA DO FACAO & $210 !$ & 5.33 & 0.47 & 89 & 0 & 0 & 0 & 0 & 210 & 0 & 0 \\
\hline CAMOAS I & $82.5 !$ & 7.91 & 0.41 & 51 & 82.5 & 0 & ! & 0 & 0 & 0 & 0 \\
\hline BARRA GRALIDE & $920 !$ & $4.4 !$ & 1.60 & 364 & 0 & 0 & 0 & 0 & 230 & 690 & 0 \\
\hline FUNIL GRAMDE & $164 !$ & 5.50 & 0.37 & 66 & 0 & 0 & 0 & 0 & 82 & 82 & 0 \\
\hline SOBRAG! & $110 !$ & 6.65 & 0.30 & 45 & 0 & 0 & 0 & 0 & 55 & 55 & 0 \\
\hline HACHADINHO & $1200 !$ & 4.26 & 2.17 & 509 & 0 & ? & 0 & ? & 1200 & ? & ? \\
\hline BARRA DO PEIXE & $450 !$ & 4.83 & 0.92 & 191 & 0 & 0 & 0 & 0 & 450 & 0 & 0 \\
\hline FOZ DO BEZERRA & $300 !$ & 5.09 & 0.65 & 127 & 0 & 0 & 0 & 0 & 300 & 0 & 0 \\
\hline MOKJOLIIHHO & $72 !$ & 8.59 & 0.26 & 31 & 0 & 0 & 0 & 0 & 72 & 0 & $?$ \\
\hline CAMOAS II & $82.5 !$ & 7.91 & 0.41 & 51 & 82.5 & 0 & ! & 0 & ? & 9 & 0 \\
\hline $101 A 1$ & $16008 !$ & 455 & 56 & 7474 & 905 & 2024 & 3055 & 3571 & 14782 & 827 & 0 \\
\hline
\end{tabular}

... CUSTO AMUAL DE OEA - COME :

56.00 
SISIEAA INIERLIGADO SUL/SUOESTE

TABELLA 26

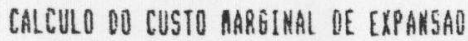

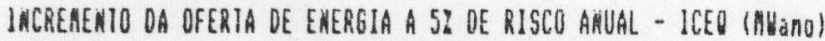

IHCREAENTO DO DEFICIT E DA GERACAO IERAICA ESPERADDS - COFE E CGTE (10Eะ6 USS)

USS $1.00=\operatorname{CRS} 155,375 \quad(0 E 2 / 90)$

$\begin{array}{lclllllllllll}\text { CUSTO AMUALILADO } & \begin{array}{c}1994 \\ \text { (inicial) }\end{array} & 1995 & 1996 & 1997 & 1998 & 1999 & 2000 & 2001 & 2002 & 2003 & 2004 & 2005 \\ \text { (final) }\end{array}$

SUBSISTERA SUL

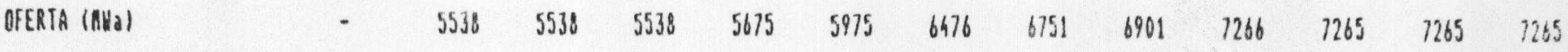

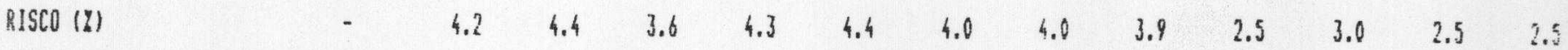

SURSISTEAA SUDESTE/C.OESIE

OFERTA (ANA) $\quad-\quad 22152 \quad 22152 \quad 22152 \quad 22709 \quad 23910 \quad 25911 \quad 27011 \quad 27611 \quad 29072 \quad 29072 \quad 29072 \quad 29072$

$\begin{array}{llllllllllllll}\text { RISCO (2) } & - & 5.3 & 5.0 & 4.7 & 5.1 & 4.9 & 5.0 & 5.2 & 5.1 & 4.8 & 5.3 & 4.4 & 4.0\end{array}$

SISIEMA IMTERLIGADO SUDESIE/C.OESTE/SUL

\begin{tabular}{|c|c|c|c|c|c|c|c|c|c|c|c|c|c|}
\hline OFERTA (ANano) & - & 27690 & 27690 & 27690 & 28384 & 29885 & 32387 & 33762 & 34512 & 36338 & 36337 & 36337 & 36337 \\
\hline InCREAENTAL (AVamo) & 4225 & 0 & 0 & 0 & 694 & 1501 & 2502 & 1375 & 750 & 1826 & -1 & 0 & $\theta$ \\
\hline DEFICII ESP. (10Fะ6 USS) & - & 642.31 & 590.96 & 500.52 & 525.60 & 610.13 & 681.13 & $732.3 !$ & 812.34 & 611.04 & 740.26 & 590.33 & 542.49 \\
\hline IHC. DEFICIT(10zis USS) & -36.76 & 0.00 & -51.35 & -90.44 & 25.08 & 84.53 & 71.00 & 51.18 & 80.03 & -201.30 & 129.22 & -149.93 & -47.26 \\
\hline
\end{tabular}

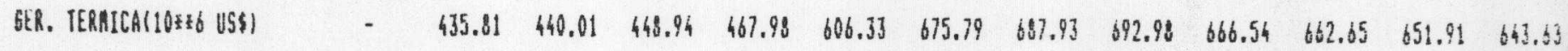

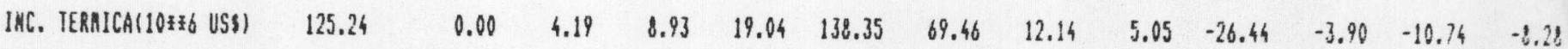

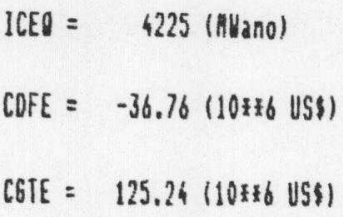

Obs: ICEQ, CDFE, CGIE corresponden ao valor presente en 1991 dos respectivos increnentos anuais.

CUSTO IAPLICITO DO DEFICIT : 480 USS/AWh 
IABELA 27

SISTERA INTERLIGADO SUL/SUDESTE

CALCULO DO CUSTO RARGINAL DE EXPAHSAO

ESIIAAIIVA DO RERCADO AIENDIOO POR NUCLEARES

USS $1.00=$ CRS 155,375 (DEL/PO)

USINA DATA FIL RATURACAO ERERGIA

$\begin{array}{lrlll}\text { A } \| R A \text { II } & \text { OEZ/197 } & & & \\ \text { (F.C.AAX.=69\%) } & 1998 & 0,69 \times 0,89 & 757.26 \\ & 1998 & 0,69 \times 0,94 & 799.80 \\ & 1999 & 0,69 \times 0,95 & 808.31 \\ & 2000 & 0,69 \times 0,98 & 833.83 \\ & 2001 & 0,69 \times 1,00 & 850.85\end{array}$

\begin{tabular}{|c|c|c|c|c|c|c|}
\hline CUSTO AMUALIZADO & & 1997 & 1998 & 1999 & 2000 & 2001 \\
\hline OFERTA (AHAMO) & & 0.00 & 757.26 & 799.80 & 808.31 & 833.83 \\
\hline IHCREAENTAL (AHano) & 484 & 0.00 & 757.26 & 42.54 & 8.51 & 25.53 \\
\hline
\end{tabular}

...EN $=464.08$ Alano 
SISTEHA INTERLIGADO SUL/SUDESTE

Tabela 28

CALCULO OO CUSTO RARGIKAL DE EXPAMSGO

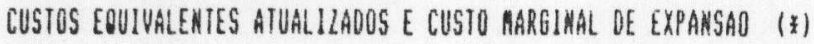

US\$ $1.00=$ CRS 155,375 (DEL/90)

INUESTIAENTO ANUAL(CATE - 107*6 USY/ano)

OFERTA DE EMERGIA IICEQ - AHano)

OFERTA daS NUCLEARES (EN - Mano)

CUSTO GERACAO IERAICA (CGIE - 105 \pm 6 US\$/año)

CUSIO DEFICII ESPERADO (CDFE - 10:ะ6 US\$/anO)

DPERACAO E MaRUTERCaO (COHE - 10FI6 U5\$/ano)

INUESIIAENTO POTENCIA (CAP+DPEO - 10F士6 USS/anO)

CUSTO DO DEFICIT (CIDE - USS/AWh)

CUSTO AARGINAL DE OPERACAO (CMO - USS/AUh)
643.96

3393.21

412.05

112.60

$-71.52$

21.07

0.00

480.00

43.59

CUSTO aARGIMAL DE EXPAKSAO (CAE - USS/AWh)

26.75

RELACAO CAE / CMO

0.61 
SISTEAA IMICLIGADO SUL/SGOESII

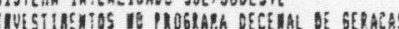

UES $1.00=$ C25 155,375 (0E2/90)

IFOA1ACOES GEQHIS

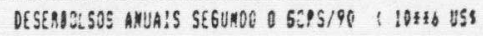

\begin{tabular}{|c|c|c|c|c|c|c|c|c|c|c|c|c|c|c|c|c|c|c|c|c|c|c|c|c|c|c|c|c|}
\hline 1 & 5 & 11 & $\therefore$ & innas & MiA & non & Gusto & cus?o & & & & & & & & & & & & & & & & & & & & \\
\hline ImS & & EARRESA & $\begin{array}{l}\text { RESE Do } \\
\text { Mojs:io }\end{array}$ & ices/9i & & : $\operatorname{lin}_{100}$ & o 85s: & $1120^{\circ} 6$ แ5s! & 1990 & 199: & $199 ?$ & 1993 & $i_{09}$ & i99: & 1996 & $199 ?$ & 1069 & 1004 & 20 & $100 \quad 21$ & 201 & 2002 & 2003 & 2006 & 2005 & 2006 & 2007 & 2000 \\
\hline
\end{tabular}

SISTERA INTERIGAaC SUL/SUDESTS

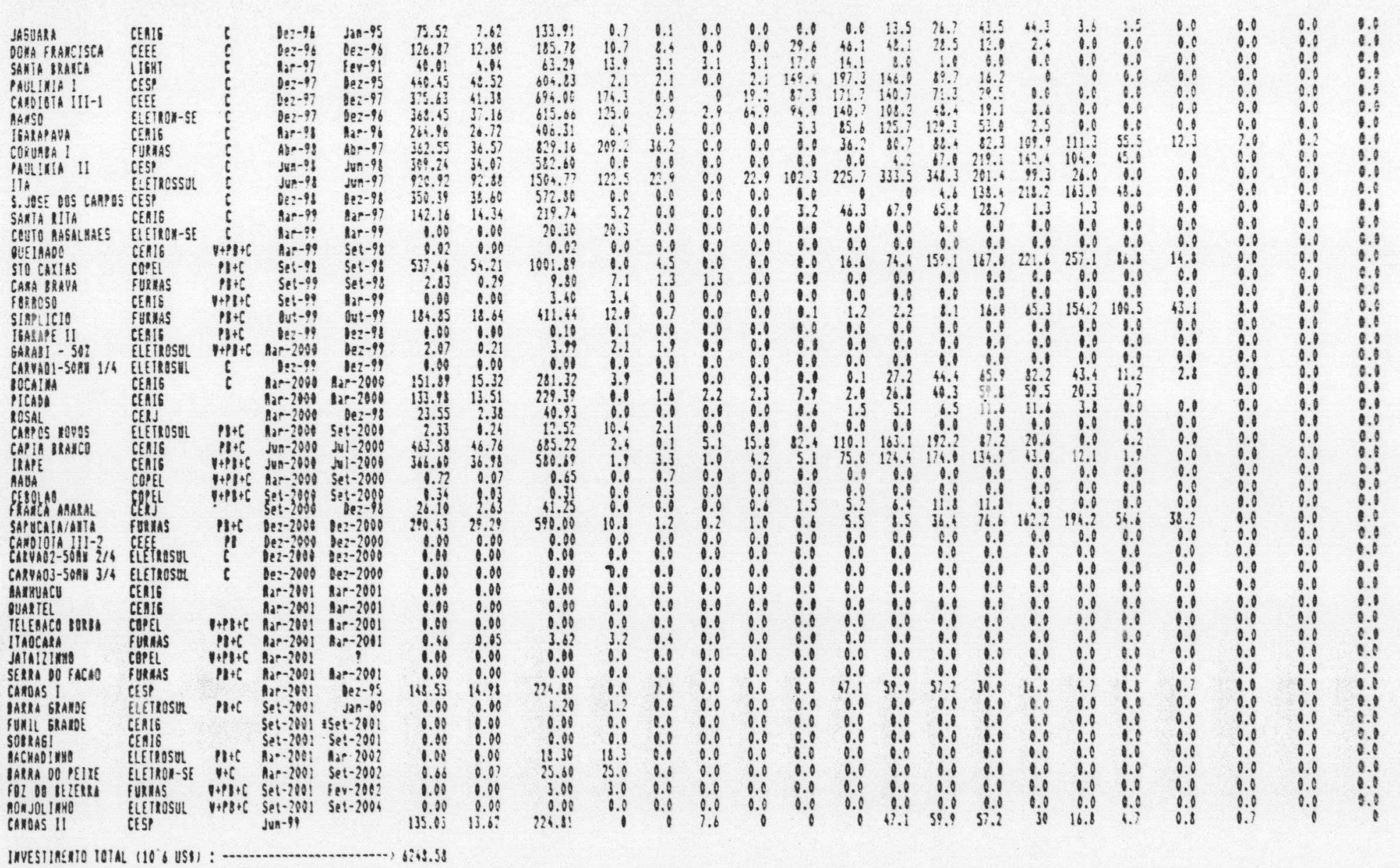

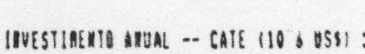

663.96

ORCAAENTO TOTAL 110 o USS): 
SISTEAA INIERLIGADO SUL/SUDESTE

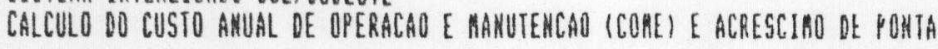

USS $1.00=$ CRS 155,375 (DE2/90)

\section{HHH Inforacoes Basicas HaH\#\#}

- constartes da curua de custo ahual de operacal e ahautehcao:

$$
\begin{aligned}
& \text { curva } 1 \text { : } \\
& \text { curva ? }
\end{aligned}
$$

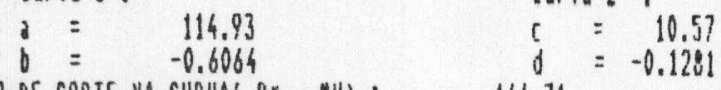

- POKTO DE CORTE HA CURVAC P\$ - AV) : 146.71

- CUSTO OE OKA (USS/KH/ano): azPOT.IKST.I"b se POT.INST. (PE OU Ez(POT.INST.Id se POT.INST > PE - taxa de atualizacho $(i$ - pU) : 0.1

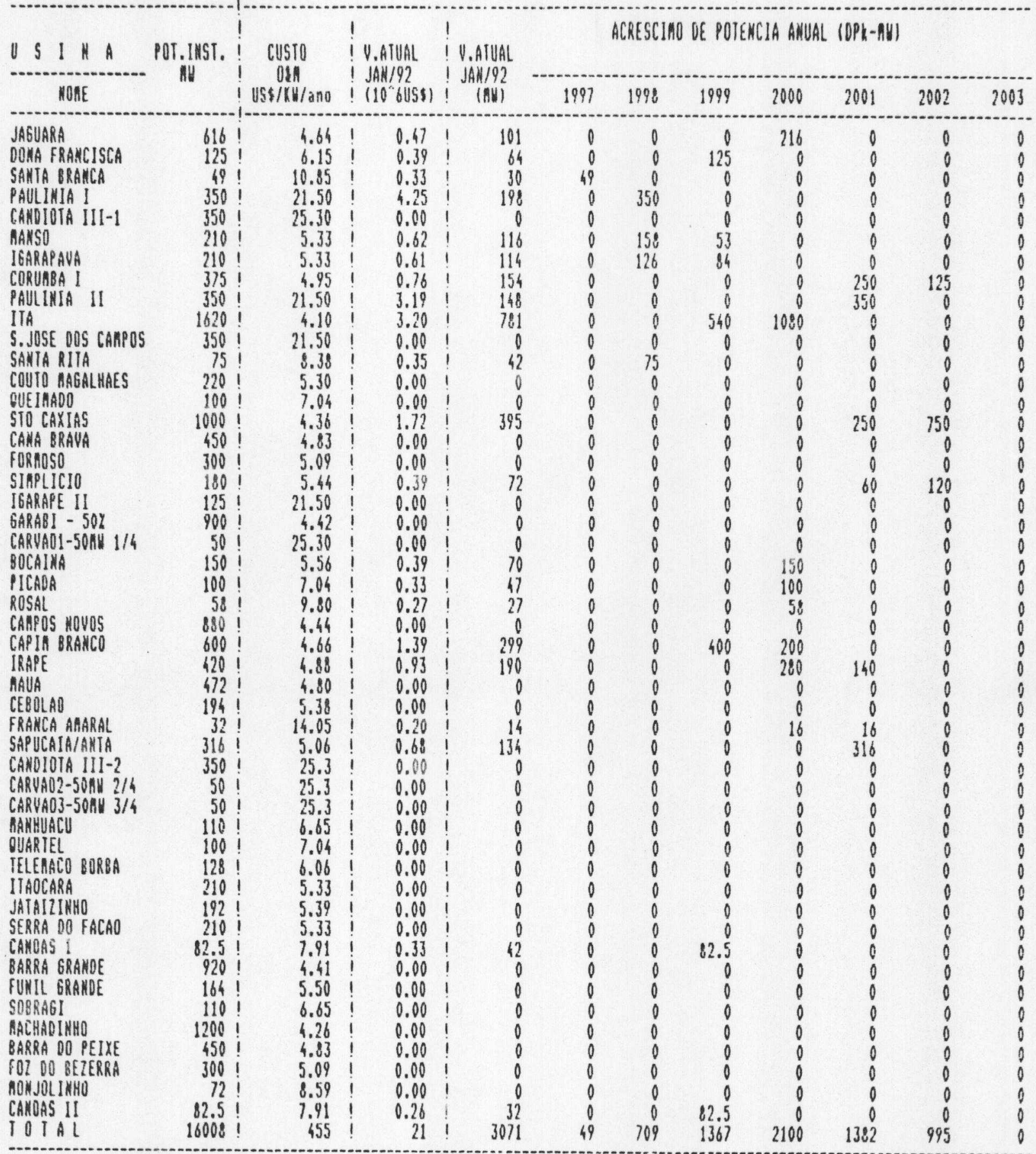

... CUSTO ANUAL DE OSH - COAE :

21.07 
SISTERA IMTERLIGADO SUL /SUDESTE

TABELA 31

CALCULO dO CUSTO MaRginaL DE EXPANGAO

INCREAENTO DA OFERTA DE ERERGIA A 5: DE RISCO ANUAL - ICEO MAHanO)

IUCREAERTO dO dEFICIT E DA GERACAO TERAICA ESPERADOS - CDFE E CGTE I10:ะ6 USSI

USS $1.00=$ CRS $155,375 \quad(0 E 2 / 90)$

\begin{tabular}{|c|c|c|c|c|c|c|c|c|c|c|c|}
\hline O AMUALLIZADO & 1994 & 1995 & 1996 & 1997 & 1998 & 1999 & 2000 & 2001 & 2002 & 2003 & 2004 \\
\hline
\end{tabular}

SUBSISIERA SUL

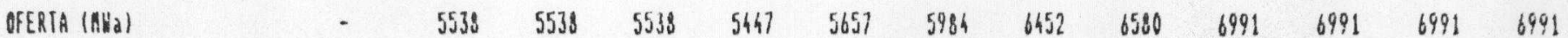

RISCO (2)

$\begin{array}{llllllllllll}4.2 & 4.4 & 3.6 & 2.7 & 3.5 & 4.5 & 4.3 & 4.9 & 2.5 & 3.0 & 2.5 & 2.5\end{array}$

SUBSISTEAA SUDESTE/C.OESIE

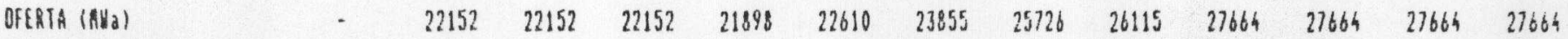

$\begin{array}{llllllllllllll}\text { RISCO (2) } & - & 5.3 & 5.0 & 4.7 & 3.0 & 4.0 & 5.1 & 5.3 & 5.9 & 4.8 & 5.3 & 4.4 & 4.9\end{array}$

SISTEHA INTERLIGADO SUDESTE/C.OESTE/SUL

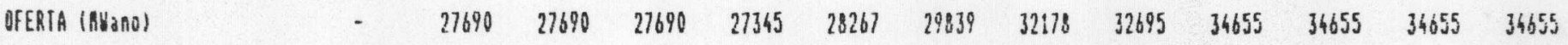

$\begin{array}{llllllllllllll}\text { IUCREAERTAL (AVลNO) } & 3393 & 0 & 0 & 0 & 0 & 922 & 1572 & 2339 & 517 & 1960 & 0 & 0 & 0\end{array}$

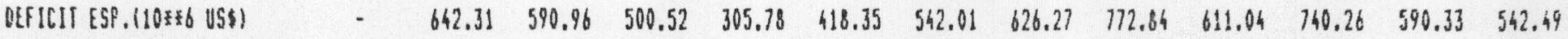

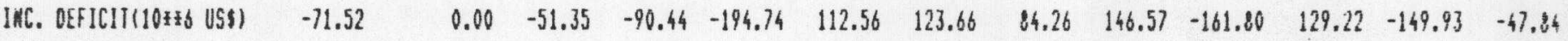

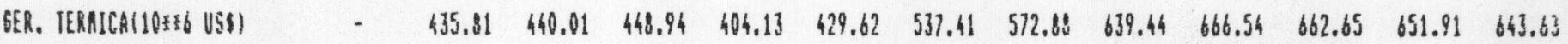

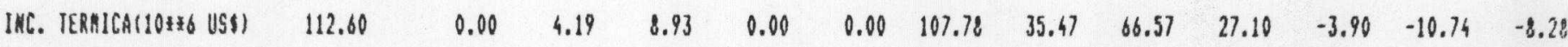
ICEO $=3393($ NIIno)
COFE $=-71.52(10 \pm \ldots 6$ USS)
CGIE $=112.60(10 \pm 16$ US\$)

Obs: ICEO, CDFE, CGTE corresponder ao valor presente en 1991 dos respectivos increaentos anuais.

CUSTO IAPLICITO DO DEFICIT : $\quad 430$ USS/AWh 
SISTENA IITERLIGADO SUL/SUOESTE

Tabela 32

CALCULO DO CUStO Marginal DE EXPAHSAO

ESIIMAIIVA dO AERCAdO AiEMOIOO POR nUCLEARES

USS 1.00 = CRS 155, 375 (DE2/190)

US INA DATA FIN hatURACAO EhERgIa

$\begin{array}{lrlll}\text { A II G R A II } & \text { DE2/97 } & & & \\ \text { (F.C.HAX, =69\%) } & 1998 & 0,69 \times 0,89 & 757.26 \\ & 1998 & 0,69 \times 0,94 & 799.80 \\ & 1999 & 0,69 \times 0,95 & 808.31 \\ & 2000 & 0,69 \times 0,98 & 833.83 \\ & 2001 & 0,69 \times 1,00 & 850.85\end{array}$

$\begin{array}{llllll}\text { CUSTO AMUALIZADO } & 1997 & 1998 & 1999 & 2000 \\ \text { OFERIA (ANano) } & & 0.00 & 0.00 & 757.26 & 799.60 \\ \text { IMCREAENTAL (ANano) } & 412 & 0.00 & 0.00 & 757.26 & 42.54\end{array}$

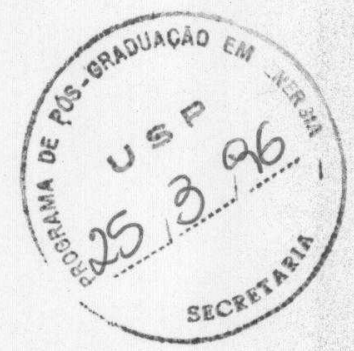

$\ldots E$ EN $=412.05$ W62no 
Tabela 33

Oferta e Risco de Déficit com Redução de 5\%

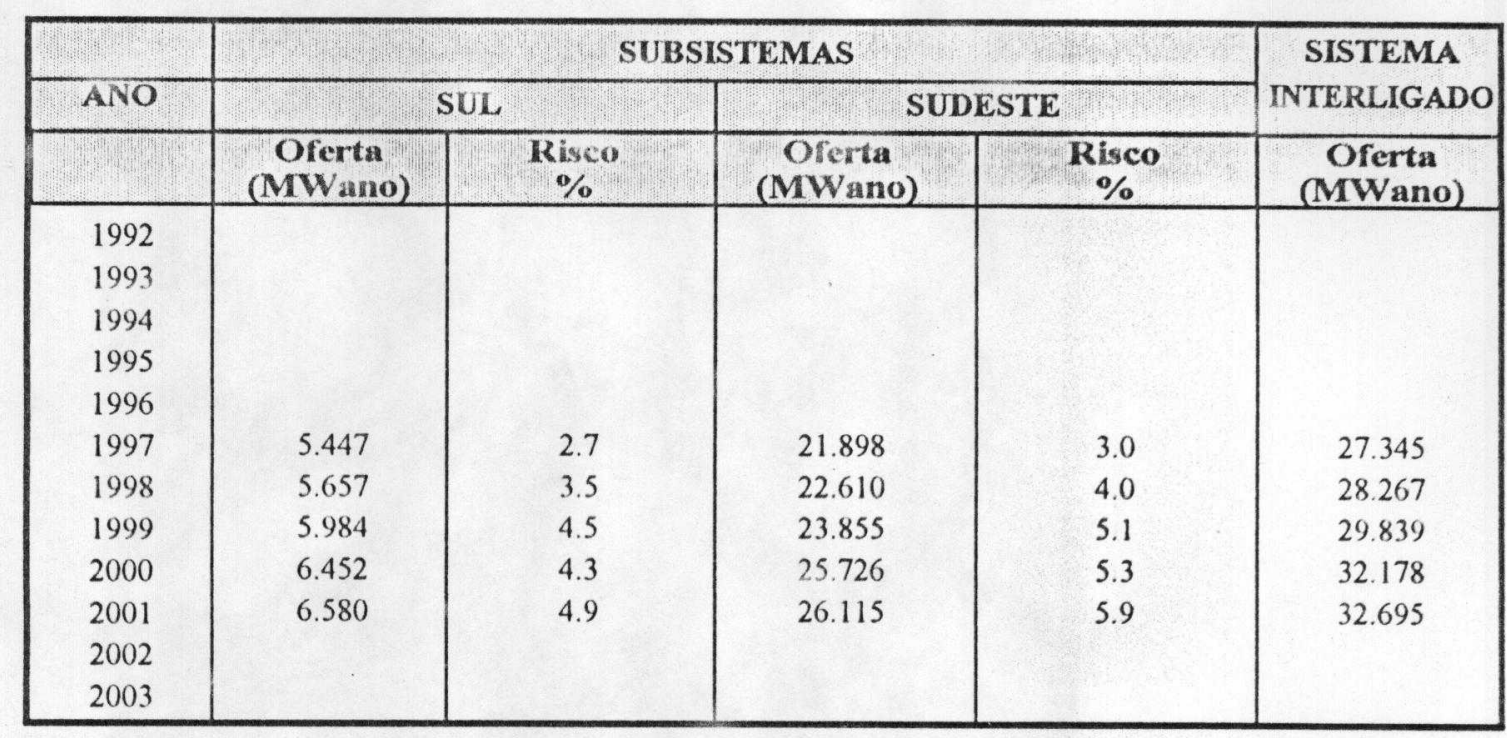

Custo Marginal de Expansão (C1') = US $\$ 26,75 / \mathrm{MWh}$ 